\title{
Selected Meteorological Data for an Arid Site Near Beatty, Nye County, Nevada, Calendar Years 1990 and 1991
}

By JAMES L. WOOD and B.J. ANDRASKI

U.S. GEOLOGICAL SURVEY

Open-File Report 94-489

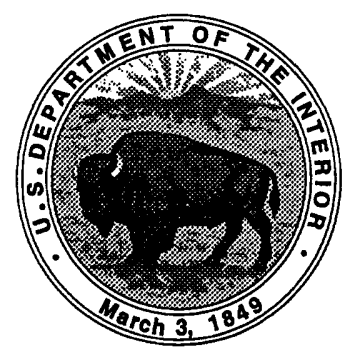

Carson City, Nevada 1995 


\title{
U.S. DEPARTMENT OF THE INTERIOR BRUCE BABBITT, Secretary
}

\author{
U.S. GEOLOGICAL SURVEY \\ GORDON P. EATON, Director
}

Any use of trade names in this publication is for descriptive purposes only and does not Imply endorsement by the U.S. Government.

For additional information write to:

\section{District Chief}

U.S. Geological Survey 333 West Nye Lane, Room 203 Carson City, NV 89706-0866
Copies of this report can be purchased from:

\section{U.S. Geological Survey} Earth Science Information Center Open-File Reports Section Box 25286, MS 517 Denver Federal Center Denver, CO 80225-0046 


\section{CONTENTS}

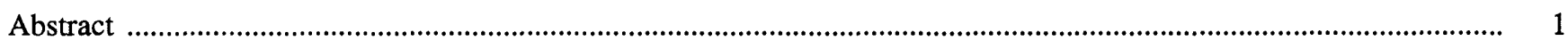

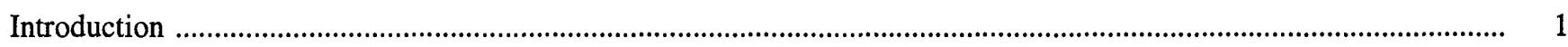

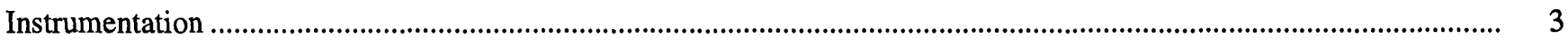

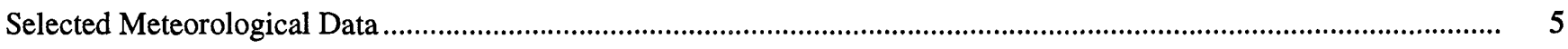

Air Temperature

Relative Humidity ….............................................................................................................................. 5

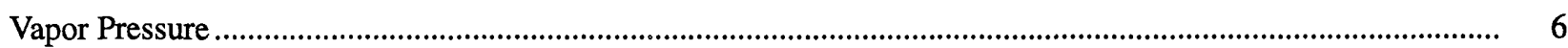

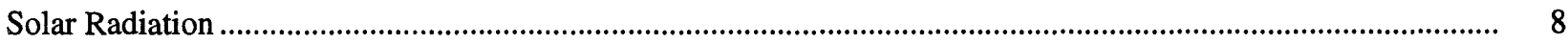

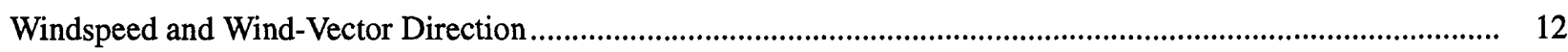

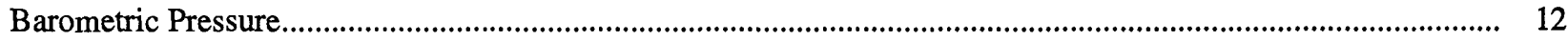

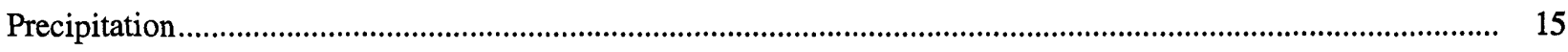

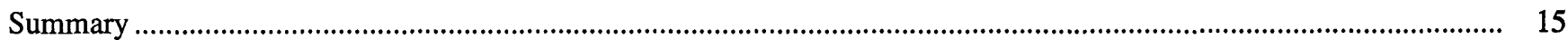

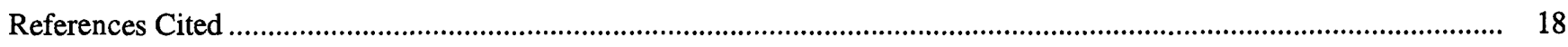

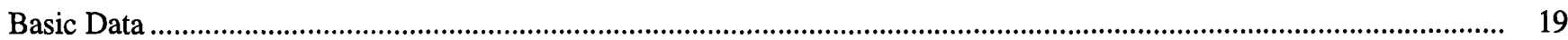

\section{FIGURES}

1-2. Maps showing location of:

1. Study site and adjacent waste-disposal facility .................................................................................... 2

2. Weather station and related unsaturated-zone monitoring shaft, psychrometer borehole, and neutron-probe access tubes at the study site.

3-7. Graphs showing meteorological data for study site, 1990 and 1991, computed from hourly averaged values:

3. Daily maximum, mean, and minimum air temperature ................................................................. 7

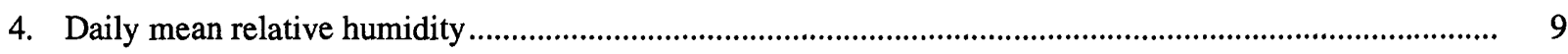

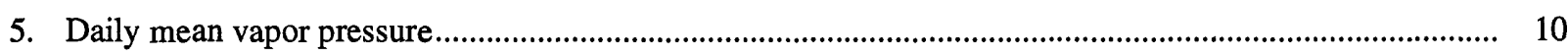

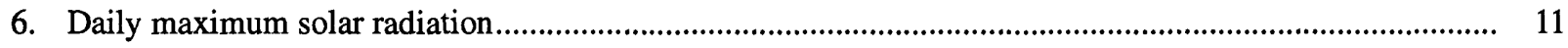

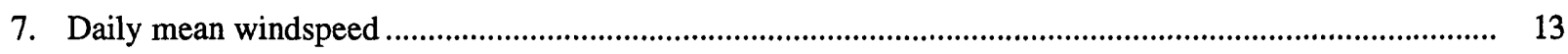

8. Graphs showing mean barometric pressure computed from 20 -minute averaged values for June through December 1990 and 10-minute averaged values for 1991 for study site................................. 14

9-10. Graphs showing precipitation at study site and two nearby sites:

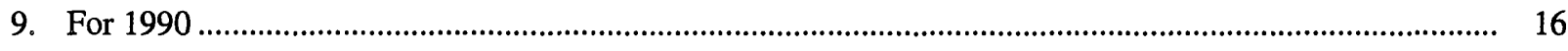

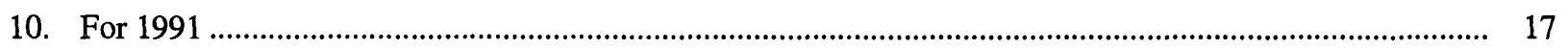

\section{TABLES}

1-4. Meteorological data for study site, 1990 and 1991:

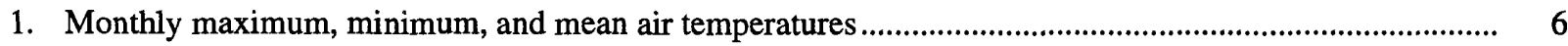

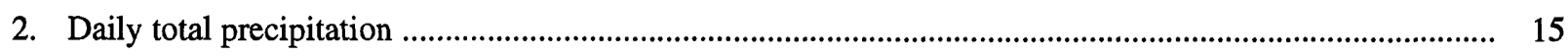

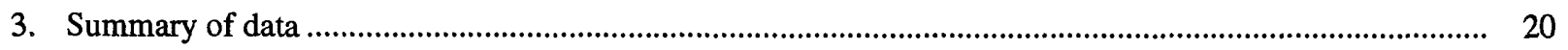

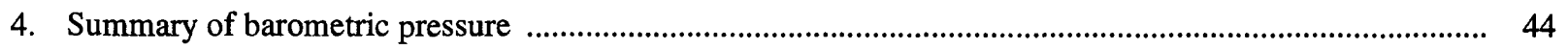


CONVERSION FACTORS AND VERTICAL DATUM

\begin{tabular}{rll}
\hline Multiply & By & To obtain \\
\hline kilometer $(\mathrm{km})$ & 0.6214 & mile \\
kilopascal $(\mathrm{kPa})$ & 0.1450 & pound per square inch \\
meter $(\mathrm{m})$ & 3.281 & foot \\
meter per second $(\mathrm{m} / \mathrm{s})$ & 3.281 & foot per second \\
millimeter $(\mathrm{mm})$ & 0.03937 & inch \\
millimeter per hour $(\mathrm{mm} / \mathrm{hr})$ & 25.40 & inch per hour \\
watt per square meter $\left(\mathrm{W} / \mathrm{m}^{2}\right)$ & 0.005290 & British Thermal Unit \\
& & per square foot per minute \\
\hline
\end{tabular}

Temperature: Degrees Celsius $\left({ }^{\circ} \mathrm{C}\right)$ can be converted to degrees Fahrenheit $\left({ }^{\circ} \mathrm{F}\right)$ by using the formula ${ }^{\circ} \mathrm{F}=\left[(1.8)\left({ }^{\circ} \mathrm{C}\right)\right]+32$.

Sea level: In this report "sea level" refers to the National Geodetic Vertical Datum of 1929 (NGVD of 1929, formerly called "Sea-Level Datum of 1929"), which is derived from a general adjustment of the first-order level networks of the United States and Canada. 


\title{
Selected Meteorological Data for an Arid Site Near Beatty, Nye County, Nevada, Calendar Years 1990 and 1991
}

\author{
By James L. Wood and B.J. Andraski
}

\section{ABSTRACT}

Selected meteorological data were collected at a study site adjacent to a low-level radioactivewaste burial facility near Beatty, Nevada, for calendar years 1990 and 1991. Data were collected in support of ongoing studies to estimate the potential for downward movement of radionuclides into the unsaturated sediments beneath waste-burial trenches at the facility. The data include air temperature, relative humidity, vapor pressure, incident solar radiation, windspeed, wind direction, barometric pressure, and precipitation. The data are summarized in tables and graphs.

Instrumentation used at the site is discussed. The discussion includes the type, reported accuracy, and mounting height of each sensor.

In 1990, the average hourly air temperatures ranged from -16.2 degrees Celsius, in December, to 44.2 degrees Celsius, in July. Hourly averaged relative humidity ranged from 6 percent to more than 90 percent. Hourly vapor pressures ranged from 0.08 to 1.84 kilopascals. Daily maximum incident solar radiation values ranged from 192 to 1,028 watts per square meter. Daily mean windspeed ranged from less than 1 to 8.7 meters per second. Wind direction was primarily from the northwest in fall, winter, and spring and varied from southeast, southwest, or northwest during the summer. Hourly barometric pressures ranged from 99.47 to 103.12 kilopascals. Total precipitation for 1990 was 32.4 millimeters; almost 45 percent was in September.

In 1991, the average hourly air temperatures ranged from -9.2 degrees Celsius, in January, to 43.7 degrees Celsius, in July. Hourly averaged relative humidity ranged from 3 percent to more than 95 percent. Hourly vapor pressures ranged from 0.07 to 2.22 kilopascals. Daily maximum incident solar radiation values ranged from 143 to 1,041 watts per square meter. Daily mean windspeed ranged from 1.2 to 8.4 meters per second. Wind direction was primarily from the northwest in fall, winter, and spring and varied from southeast, southwest, or northwest during the summer. Hourly barometric pressures ranged from 99.52 to 103.40 kilopascals. Total precipitation for 1991 was 103.6 millimeters; almost 60 percent was in March.

\section{INTRODUCTION}

Meteorological data were collected near the low-level radioactive-waste burial facility near Beatty, Nev., in support of ongoing studies (Andraski, 1990; Fischer, 1992) to estimate the potential for downward movement of radionuclides into the unsaturated sediments beneath waste-burial trenches at the facility (fig. $1 B$ ). This report presents and summarizes meteorological data collected for calendar years 1990 and 1991. Instrumentation used to collect the data is described also. This report is one in a series of meteorological data reports published for this site 

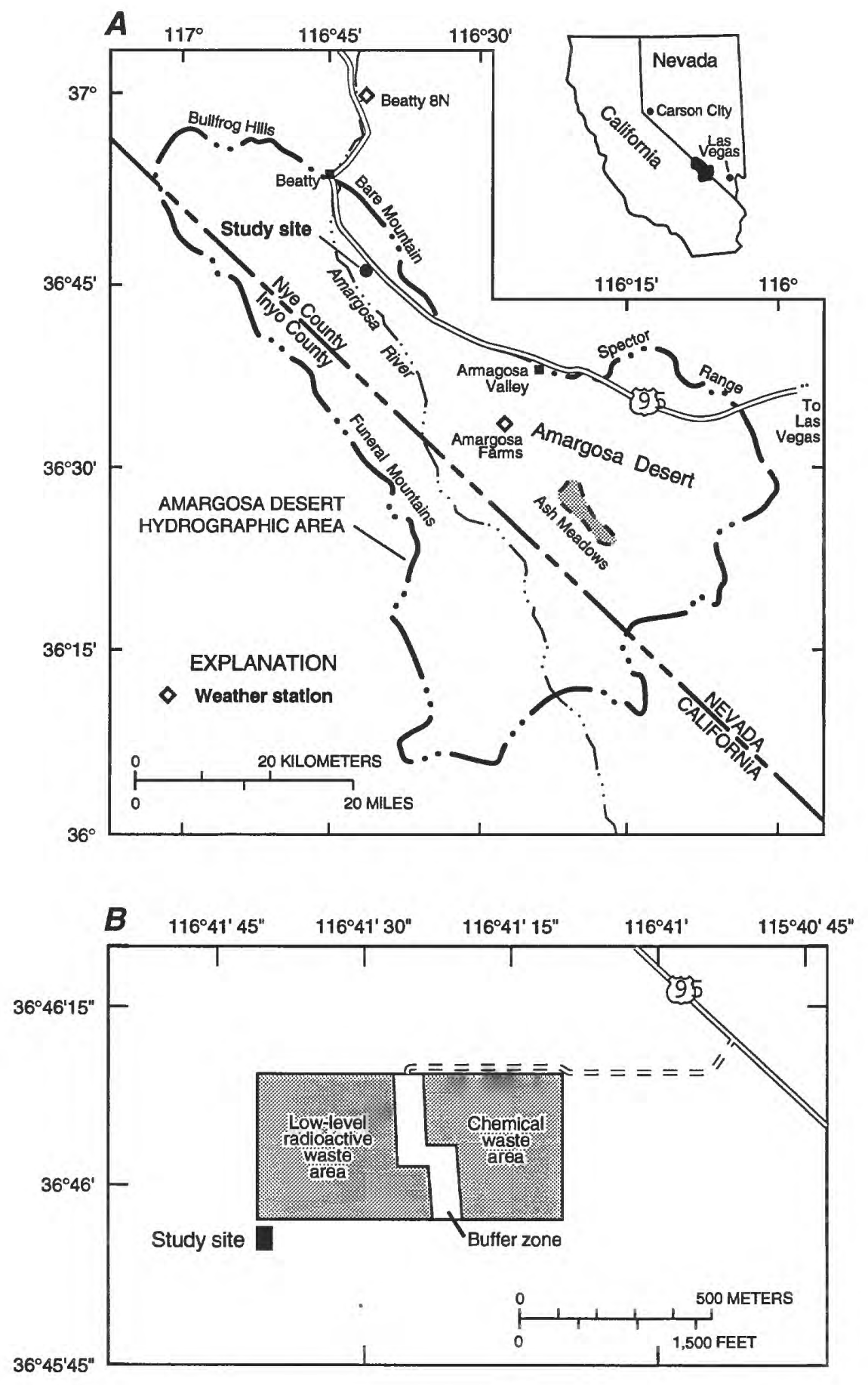

Figure 1. Location of study site and adjacent waste-disposal facility.

(Wood and Fischer, 1991, 1992; Wood and Andraski, 1992; Wood and others, 1992). The meteorological data collected include air temperature, relative humidity, vapor pressure, incident solar radiation, windspeed, wind direction, barometric pressure, and precipitation.
The waste-burial facility in the Amargosa Desert, $17 \mathrm{~km}$ southeast of Beatty and $169 \mathrm{~km}$ northwest of Las Vegas, Nev. (fig. 1A), has been operating since 1962. The disposal facility was the first commercially operated in the United States. At this facility, 
waste is emplaced in 2- to 15-m deep trenches and covered by backfilling with previously excavated materials. The Amargosa Desert in the vicinity of the waste-burial facility is a northwest trending valley about $13 \mathrm{~km}$ wide. Vegetation is sparse, with creosote bush (Larrea tridentata) the dominant species.

The study site (altitude $847 \mathrm{~m}$ above sea level), is in one of the most arid parts of the United States. Precipitation is highly variable. Mean annual precipitation is about $114 \mathrm{~mm}$ at Beatty (altitude, 1,005 m), and $74 \mathrm{~mm}$ at Amargosa Farms (formerly Lathrop Wells; altitude, $817 \mathrm{~m}$ ), $30 \mathrm{~km}$ southeast of the site (Nichols, 1987, p. 15). No perennial streams are within $16 \mathrm{~km}$ of the site and the dry bed of the Amargosa River is the principal drainage channel (fig. 1A).

A detailed view of part of the study site is shown in figure 2 . The site is enclosed by a chainlink fence approximately $2 \mathrm{~m}$ high topped with $1 / 2 \mathrm{~m}$ of razor ribbon and is patrolled by security from the adjacent commercial waste-disposal facility; this provides protection against vandalism. In addition to the meteorological station data, unsaturated-zone data are collected from three neutron-probe access tubes and from sensors installed at several depths in a monitoring shaft (fig. 2). An undisturbed area is maintained on one side of the shaft site where no foot or vehicle traffic is allowed except on a designated foot path. A description of this unsaturatedzone monitoring is presented by Fischer (1992).

\section{INSTRUMENTATION}

\section{January 1 through May 14, 1990}

Meteorological sensors consisted of an air temperature and relative humidity sensor, silicon pyranometer, anemometer, wind vane, and tippingbucket rain gage. All sensors were factory calibrated prior to installation in the fall of 1984. Data from the sensors were recorded using a Campbell Scientific, Inc. (CSI) CR21 datalogger (Campbell Scientific, Inc., 1984). All instruments were mounted on a CSI CM10 tripod. Both the anemometer and wind vane were mounted $3.4 \mathrm{~m}$ above land surface. The air temperature/relative humidity probe was mounted inside a CSI model 041 sensor shield $1.7 \mathrm{~m}$ above land surface. The tipping-bucket rain gage was mounted $2.2 \mathrm{~m}$ above land surface and the silicon pyranometer
$3.7 \mathrm{~m}$ above land surface. All heights are approximate. The weather station is approximately $40 \mathrm{~m}$ from the CSI datalogger, housed in a shed on the site (fig. 2).

The anemometer is a model 014A, supplied by MET ONE ${ }^{1}$, with an accuracy of 1.5 percent and a threshold of $0.45 \mathrm{~m} / \mathrm{s}$. The wind vane is a model $024 \mathrm{~A}$, also from MET ONE, and has a specified accuracy of \pm 5 degrees and a threshold of $0.45 \mathrm{~m} / \mathrm{s}$. The temperature/relative humidity probe was a CSI model 207 with a temperature accuracy of $\pm 0.4^{\circ} \mathrm{C}$ in a range of $-33^{\circ} \mathrm{C}$ to $48^{\circ} \mathrm{C}$ and a relative humidity accuracy of \pm 5 percent in a range of 12- to 100-percent relative humidity. The tipping-bucket rain gage is a Weathermeasure model P-501 with a sensitivity and resolution of $0.25 \mathrm{~mm}$ and an accuracy of 0.5 percent at $12.7 \mathrm{~mm} / \mathrm{hr}$. The silicon pyranometer is a LICOR LI200S calibrated against an Eppley Precision Spectral Pyranometer, which has a maximum error of \pm 5 percent.

\section{May 14, 1990, through December 31, 1991}

Beginning in 1990, all Beatty meteorological sensors were scheduled to be removed, replaced, and then calibrated on an annual basis. On May 14, 1990, meteorological sensors and the datalogger, which had been in use at the site since October 1984, were replaced. The CR21 datalogger was replaced with a CSI $21 \mathrm{XL}$.

Windspeed, wind direction, solar radiation, and precipitation measuring devices were replaced with identical instruments during the reinstrumentation procedure. The CSI model 207 temperature/relative humidity probe was replaced with another CSI model 207 probe on May 14, 1990, and this probe was replaced with a Vaisala HMP35C probe from CSI on June 28, 1990.

The Vaisala probe is capable of making measurements over a full range of $0-100$ percent relative humidity. The $0-10$ percent range is of particular interest at the arid study site near Beatty. Vaisala advertises its accuracy at $20^{\circ} \mathrm{C}$ against factory references at \pm 1 percent relative humidity ( 0 to 90 percent relative humidity), and against field references at \pm 2 percent relative humidity ( 0 to 90 percent relative humidity), and \pm 3 percent relative humidity ( 90 to 100 percent relative humidity). Temperature dependence is listed as \pm 0.04 percent relative humidity/ degrees Celsius, with a typical long-term

\footnotetext{
${ }^{1}$ All sensor specifications supplied by manufacturers.
} 


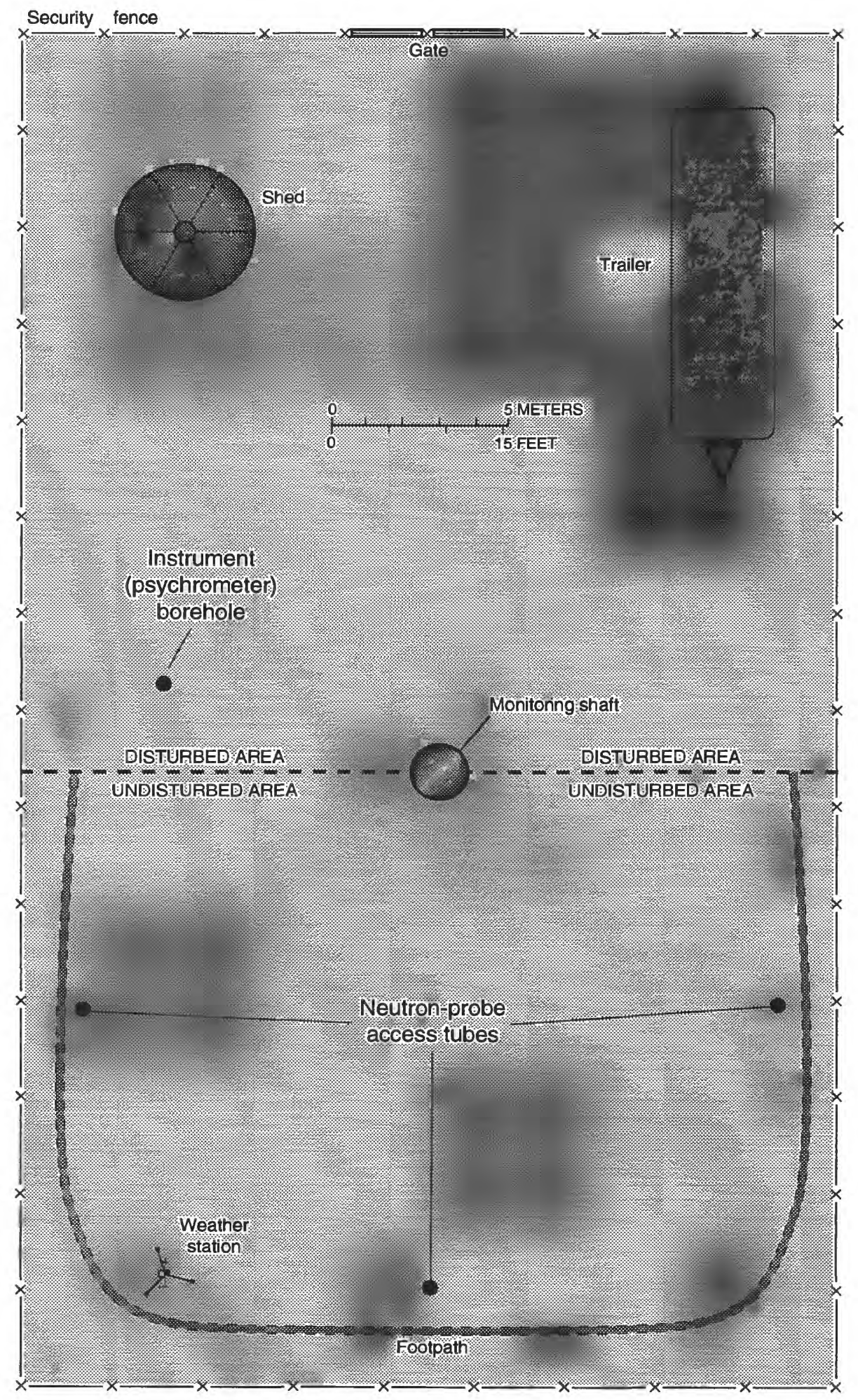

Figure 2. Location of weather station and related unsaturated-zone monitoring shaft, psychrometer borehole, and neutron-probe access tubes at study site near Beatty, Nev. Monitoring shaft is used to measure water potentials and neutron-probe access tubes are used to measure moisture content. Location of study site is shown in figure 1. 
stability better than 1 percent relative humidity per year. The "worst case" temperature accuracy is $\pm 0.4^{\circ} \mathrm{C}$ over the range of -33 to $+48^{\circ} \mathrm{C}$. The Vaisala probe was mounted inside a 12-plate Gill radiation shield from CSI.

A CSI SBP270 barometric pressure sensor was installed at the site in June 1990. This sensor has a range of 80 to 110 kilopascals $(\mathrm{kPa})$, and an accuracy of $\pm 0.02 \mathrm{kPa}$. The barometer was mounted inside the shed (fig. 2). Because of instrument cost, the barometer was not scheduled for annual rotation with an equivalent sensor.

The mounting heights of the sensors also were adjusted in 1990 to comply with preliminary suggested standards of the American Association of State Climatologists, which is attempting to standardize automated weather stations (Kunkel, 1988, p. 3-5). The temperature/relative humidity sensor height was lowered from 1.7 to $1.6 \mathrm{~m}$ above land surface. Sensor heights for the windspeed and wind direction sensors remained at $3.4 \mathrm{~m}$. The solar radiation sensor was mounted on a horizontal arm and lowered from $3.7 \mathrm{~m}$ to $3.0 \mathrm{~m}$, and the precipitation tipping bucket was installed on a separate mount about $10 \mathrm{~m}$ from the tripod and lowered from a height of $2.2 \mathrm{~m}$ to $1.0 \mathrm{~m}$.

On July 30, 1991, temperature/relative humidity, solar radiation, windspeed, wind direction, and precipitation measuring devices were replaced with identical instruments that had been factory calibrated.

\section{SELECTED METEOROLOGICAL DATA}

From January 1 to May 14, 1990, measurements from all meteorological instruments, except the tipping-bucket rain gage, were recorded with a CR21 datalogger every 60 seconds. From May 14, 1990, through December 31, 1991, these measurements were recorded with a CR21XL datalogger every 10 seconds, except for the barometric data, which were recorded every 30 seconds. The dataloggers used these measurements to compute hourly averages for air temperature, relative humidity, solar radiation, windspeed, wind direction, and a standard deviation of the wind direction. Before January 1, 1991, barometric pressure was averaged every 20 minutes; after January 1, 1991, data were averaged every 10 minutes. Precipitation was recorded at 5-minute intervals only during rainfall, and totaled for each day.
Before January 1, 1991, the hourly averaged and totaled precipitation values were automatically retrieved from the datalogger and transferred to a Prime minicomputer using telecommunications and a computer program called ADAREPS, which is an acronym for Automatic DAta REtrieval and Processing System (John Walker, U.S. Geological Survey, written commun., 1986). Data from the datalogger were retrieved twice daily. After January 1, 1991, the data were automatically retrieved daily by a personal computer using CSI software. A cassette tape connected to the datalogger was used as a backup to the automatic data retrieval system.

The hourly averaged values were used to compute daily means, maximums, and minimums for air temperature, relative humidity, solar radiation, windspeed, wind direction, and barometric pressure, which are summarized in tables 3 and 4 at the end of this report. Due to telecommunication or datalogger failures, 18 days in 1990 had no reported values. An additional 20 days had missing hourly values, and of these, 11 had less than 19 hourly values reported. Data are complete for calendar year 1991.

\section{Air Temperature}

Hourly averaged values of maximum and minimum air temperatures for each month, and a monthly mean value, are listed in table 1 . In 1990, the minimum temperature was $-16.2^{\circ} \mathrm{C}$ in December and the maximum was $44.2^{\circ} \mathrm{C}$ in July. In 1991 , the minimum temperature was $-9.2^{\circ} \mathrm{C}$ in January and the maximum temperature was $43.7^{\circ} \mathrm{C}$ in July.

Both seasonal and daily temperature fluctuations are large in the study area. Differences between hourly averaged daily maximum and minimum temperatures commonly exceed $20^{\circ} \mathrm{C}$. The difference between winter minimum and summer maximum temperatures averages more than $50^{\circ} \mathrm{C}$. Maximum, mean, and minimum daily temperatures for 1990 and 1991 are shown in figure 3.

\section{Relative Humidity}

Relative humidity is the ratio of the amount of water vapor in the air at a specific temperature to the maximum amount of water vapor the air can hold at that temperature and is expressed as a percent. 
Tabie 1. Monthly maximum, minimum, and mean air temperatures at study site, near Beatty, Nev., for 1990 and 1991

[Temperatures are degrees Celsius. Hourly averaged values.]

1990

\begin{tabular}{|c|c|c|c|c|c|}
\hline Month & Maximum & Day & MInImum & Day & Mean \\
\hline $\begin{array}{l}\text { January } \\
\text { February } \\
\text { March } \\
\text { April }\end{array}$ & $\begin{array}{l}23.2 \\
25.5 \\
29.9 \\
32.6\end{array}$ & $\begin{array}{l}10 \\
23 \\
23 \\
28\end{array}$ & $\begin{array}{r}-2.3 \\
-8.1 \\
-2.3 \\
6.3\end{array}$ & $\begin{array}{r}7 \\
16 \\
12 \\
1\end{array}$ & $\begin{array}{r}7.0 \\
8.0 \\
14.4 \\
19.4\end{array}$ \\
\hline $\begin{array}{l}\text { May } \\
\text { June } \\
\text { July } \\
\text { August }\end{array}$ & $\begin{array}{l}35.2 \\
42.8 \\
44.2 \\
43.4\end{array}$ & $\begin{array}{r}7 \\
30 \\
12 \\
5\end{array}$ & $\begin{array}{r}7.6 \\
8.5 \\
12.8 \\
7.8\end{array}$ & $\begin{array}{l}29 \\
26 \\
18 \\
14\end{array}$ & $\begin{array}{l}22.1 \\
28.3 \\
31.4 \\
28.7\end{array}$ \\
\hline $\begin{array}{l}\text { September } \\
\text { October } \\
\text { November } \\
\text { December }\end{array}$ & $\begin{array}{l}39.6 \\
32.4 \\
27.6 \\
20.8\end{array}$ & $\begin{array}{r}9 \\
4 \\
10 \\
5\end{array}$ & $\begin{array}{r}13.1 \\
2.7 \\
-4.4 \\
-16.2\end{array}$ & $\begin{array}{r}17 / 27 \\
21 \\
29 \\
23\end{array}$ & $\begin{array}{r}22.8 \\
18.6 \\
11.1 \\
2.6\end{array}$ \\
\hline \multicolumn{6}{|c|}{1991} \\
\hline $\begin{array}{l}\text { January } \\
\text { February } \\
\text { March } \\
\text { April }\end{array}$ & $\begin{array}{l}20.4 \\
24.6 \\
21.5 \\
28.6\end{array}$ & $\begin{array}{r}13 \\
20 \\
31 \\
6\end{array}$ & $\begin{array}{r}-9.2 \\
-2.5 \\
-2.1 \\
2.9\end{array}$ & $\begin{array}{r}1 \\
2 \\
16 \\
11\end{array}$ & $\begin{array}{r}6.2 \\
11.8 \\
9.5 \\
15.8\end{array}$ \\
\hline $\begin{array}{l}\text { May } \\
\text { June } \\
\text { July } \\
\text { August }\end{array}$ & $\begin{array}{l}33.7 \\
38.8 \\
43.7 \\
40.1\end{array}$ & $\begin{array}{r}24 \\
10 \\
5 \\
25\end{array}$ & $\begin{array}{r}4.4 \\
11.3 \\
17.1 \\
13.0\end{array}$ & $\begin{array}{r}11 \\
2 \\
21 \\
29\end{array}$ & $\begin{array}{l}19.4 \\
26.0 \\
30.6 \\
28.9\end{array}$ \\
\hline $\begin{array}{l}\text { September } \\
\text { October } \\
\text { November } \\
\text { December }\end{array}$ & $\begin{array}{l}38.8 \\
35.6 \\
28.8 \\
19.6\end{array}$ & $\begin{array}{l}5 \\
4 \\
7 \\
6\end{array}$ & $\begin{array}{l}12.0 \\
-1.4 \\
-4.3 \\
-4.9\end{array}$ & $\begin{array}{l}11 \\
29 \\
30 \\
17\end{array}$ & $\begin{array}{r}25.9 \\
21.4 \\
11.3 \\
6.3\end{array}$ \\
\hline
\end{tabular}

Daily mean, maximum, and minimum relative humidity values computed from hourly averaged values are listed in table 3. Daily mean relative humidity values are shown in figure 4 . In 1990, hourly averaged values ranged from about 6 percent during the drier summer months to more than 90 percent during one September storm event. In 1991, hourly averaged values ranged from 3 percent during drier summer months, to more than 95 percent during winter storm events. Extremes of daily mean values for the period of January 1 to May 14, 1990, might actually be somewhat less than 12 percent and more than 80 percent, but not reported due to lack of sensor (CSI model 207 probe) accuracy in these ranges.

\section{Vapor Pressure}

Water vapor content of air can be expressed in terms of the partial pressure exerted by the water vapor, or vapor pressure (Campbell, 1986, p. 21). Vapor pressure at a given ambient air temperature was determined by first calculating the saturation vapor pressure at that particular temperature. The saturation vapor pressure is defined as the highest concentration of water vapor that can exist in equilibrium with a plane, free water surface at a given temperature. This value was obtained by using the formula from Lowe (1977):

$$
\begin{aligned}
& E=a_{0}+a_{1} T+a_{2} T^{2}+a_{3} T^{3} \\
& +a_{4} T^{4}+a_{5} T^{5}+a_{6} T^{6}
\end{aligned}
$$




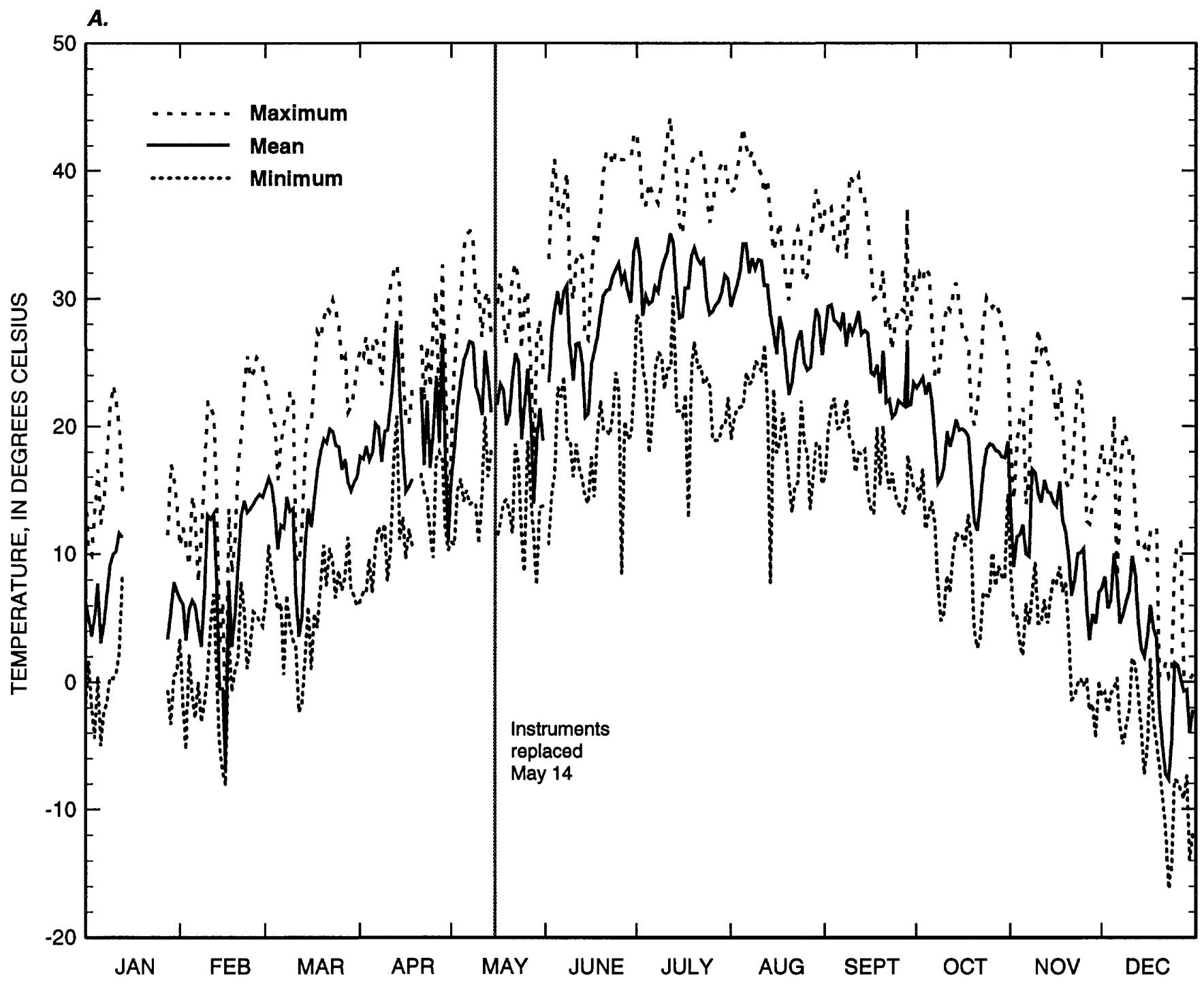

Figure 3. Daily maximum, mean, and minimum air temperature computed from hourly averaged values for $(A) 1990$ and $(B) 1991$ for study site near Beatty, Nev.

where $E$ is saturation vapor pressure, in millibars;

$T$ is temperature, in degrees Celsius; and

$a_{\mathrm{i}}$ is numerical constant for each term of the polynomial $(i=0,1, \ldots 6)$.

The numerical constants in equation 1 are as follows:

$$
\begin{aligned}
& a_{0}=6.10779991 \\
& a_{1}=4.436518521 \times 10^{-1} \\
& a_{2}=1.428945805 \times 10^{-2} \\
& a_{3}=2.650648471 \times 10^{-4} \\
& a_{4}=3.031240396 \times 10^{-6} \\
& a_{5}=2.034080948 \times 10^{-8} \\
& a_{6}=6.136820929 \times 10^{-11}
\end{aligned}
$$

The saturation vapor pressure value was then divided by 10 to convert from millibars to kilopascals. Before September 4, 1991, ambient vapor pressure was determined by multiplying the hourly saturation vapor pressure by the hourly averaged relative humidity. After September 4, 1991, ambient vapor pressures were calculated by the datalogger each time temperature and relative humidity were measured (10 seconds).

Daily mean, maximum, and minimum values of vapor pressure are listed in table 3 . Daily mean vapor pressures computed from hourly averaged values of temperature and relative humidity are shown in figure 5. In 1990, hourly vapor pressures ranged from a maximum of $1.84 \mathrm{kPa}$ in July to a minimum 
B.

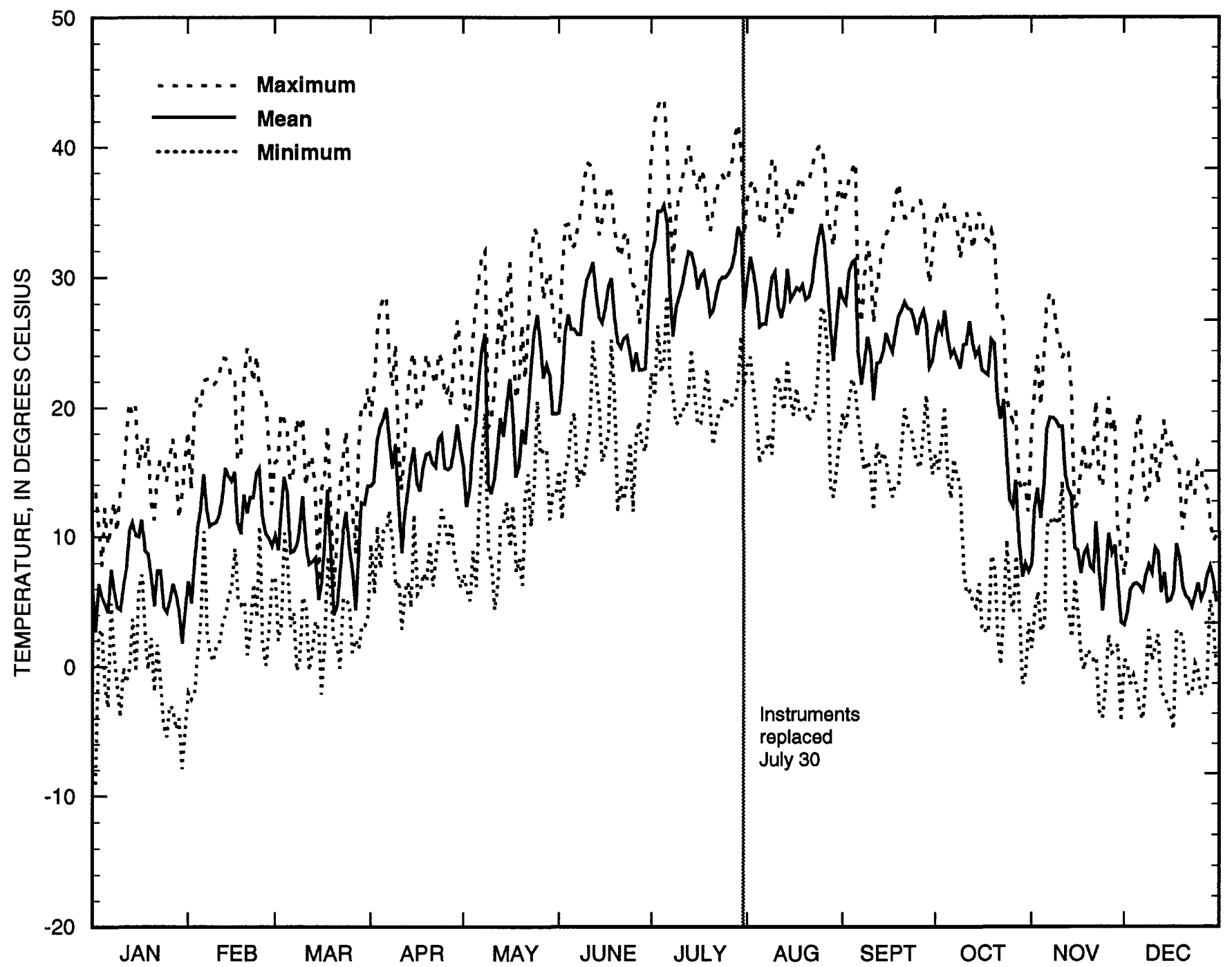

Figure 3. Continued

of $0.08 \mathrm{kPa}$ in February. In 1991, hourly vapor pressures ranged from of $2.22 \mathrm{kPa}$ in July to $0.07 \mathrm{kPa}$ in January. Vapor pressures have generally higher base pressures during the warmer summer months and lower base pressures during cooler winter conditions (fig. 5). Vapor-pressure peaks throughout the year generally correlate with precipitation see table 2 and figs. 9C and $10 \mathrm{C}$.

\section{Solar Radiation}

Daily mean and maximum daily incident solar radiation computed from hourly averaged values are listed in table 3. Incident solar radiation (short wave) is the amount of radiation that reaches the earth without interception. Generally, daily mean and maximum daily radiation were highest from May through August, and lowest from November through February, coinciding with seasonal cycles.

Maximum solar radiation values computed from hourly averaged values for each day are shown in figure 6. In 1990, the daily maximum solar radiation values ranged from $192 \mathrm{~W} / \mathrm{m}^{2}$ on November 19 , to $1,028 \mathrm{~W} / \mathrm{m}^{2}$ on May 8. In 1991 , the daily maximum solar radiation values ranged from $143 \mathrm{~W} / \mathrm{m}^{2}$ on November 15 , to $1,041 \mathrm{~W} / \mathrm{m}^{2}$ on May 11 . 
A.

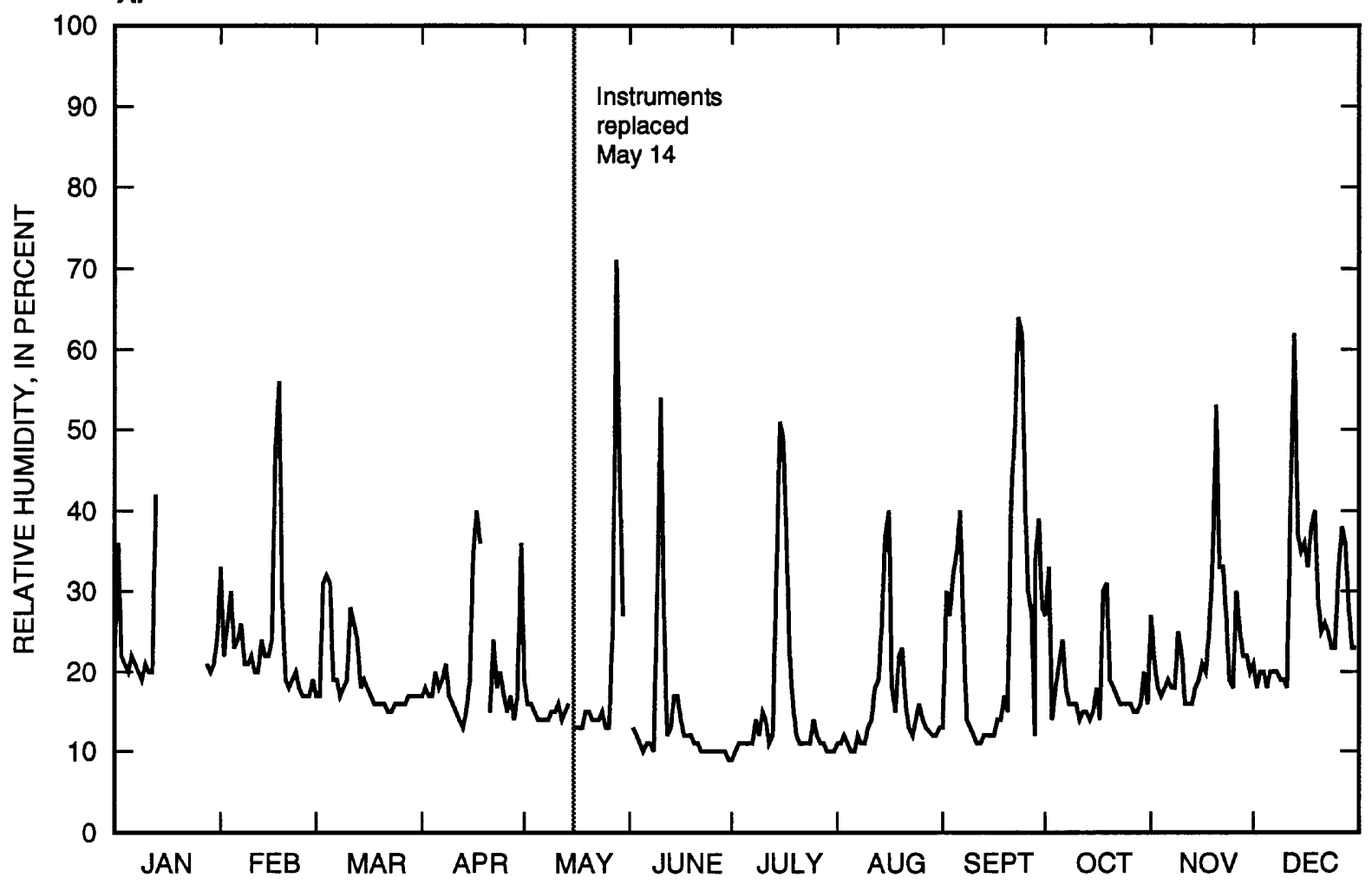

B.

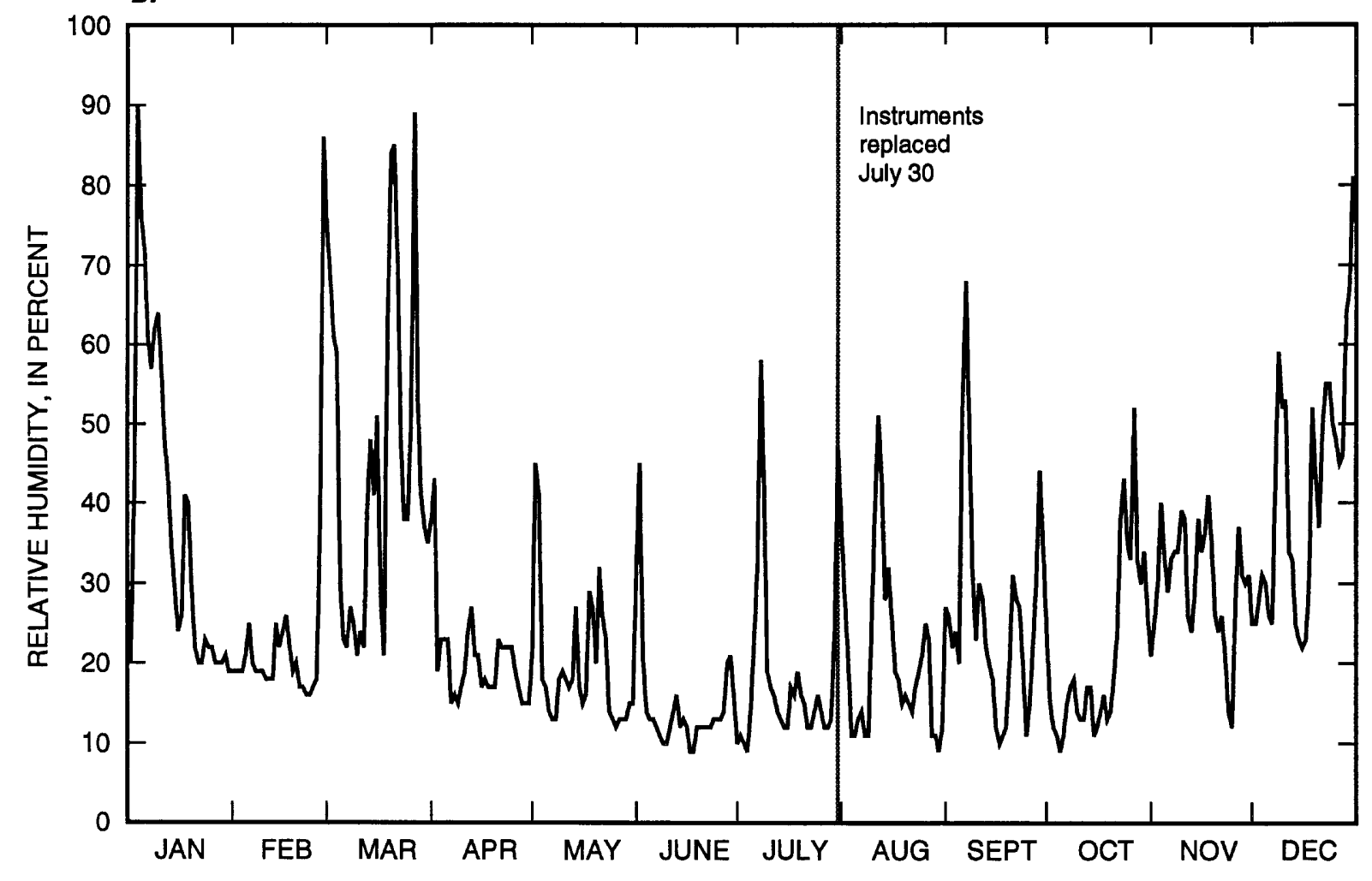

Figure 4. Daily mean relative humidity computed from hourly averaged values for $(A) 1990$ and $(B) 1991$ for study site near Beatty, Nev. 
A.

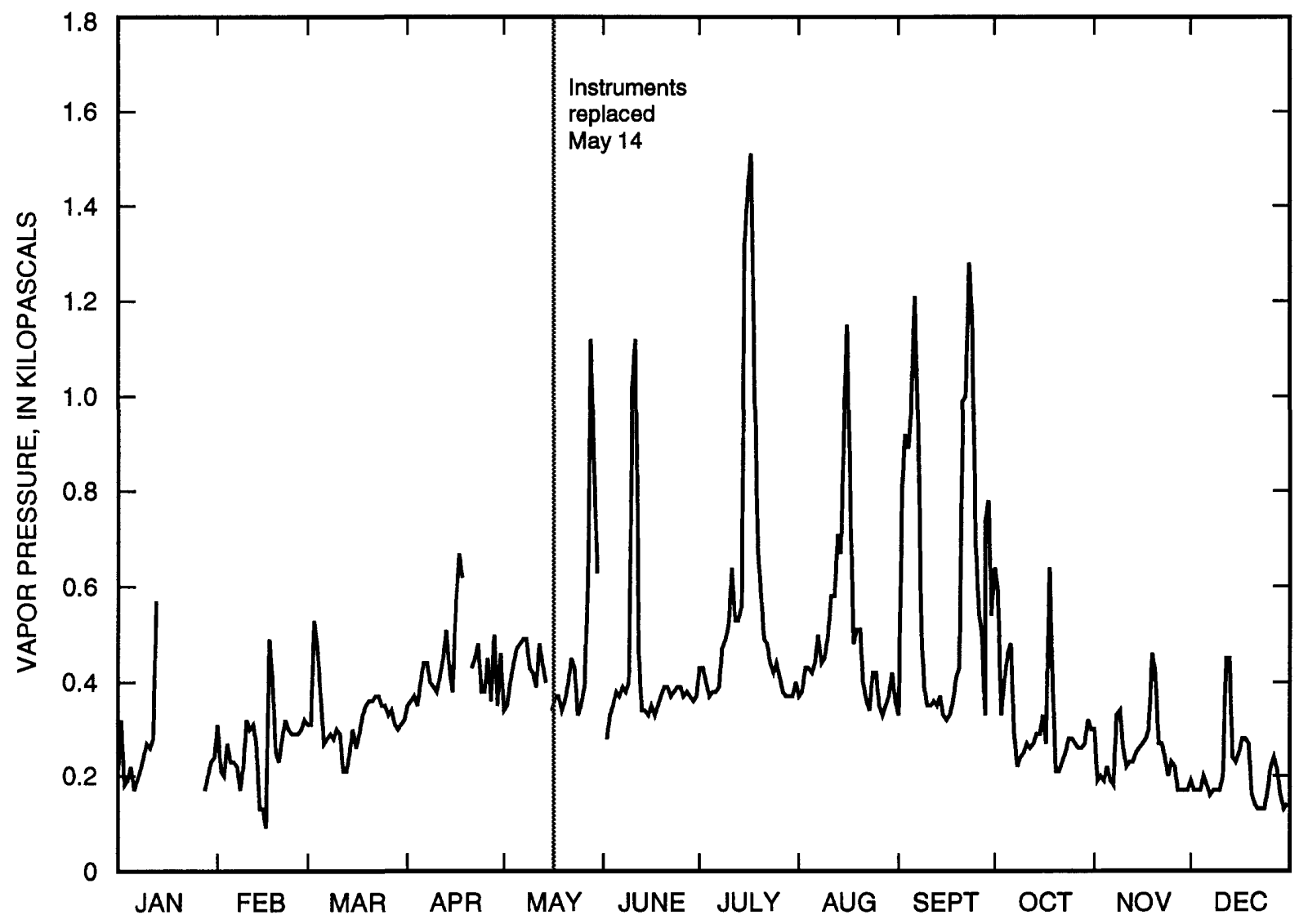

B.

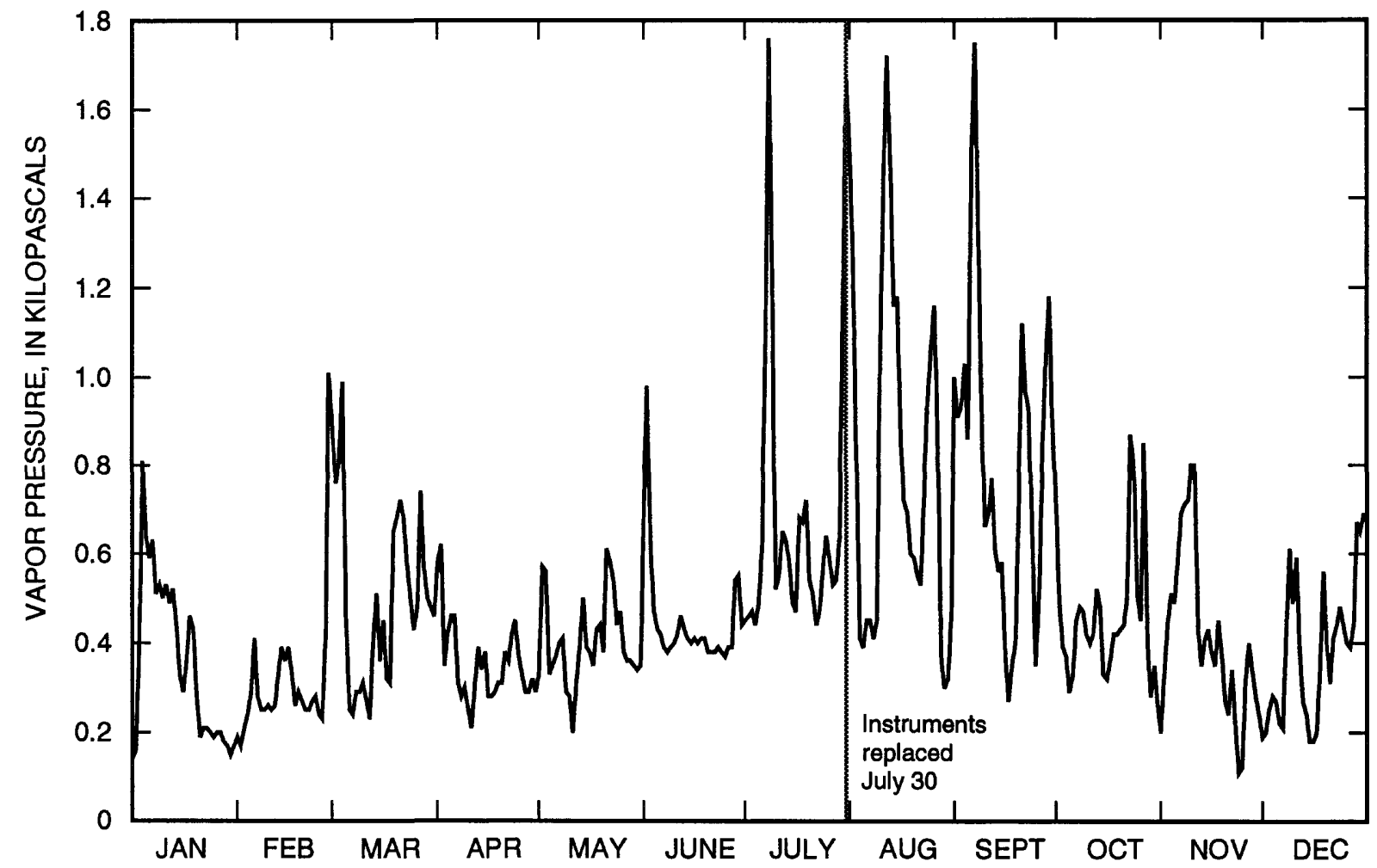

Figure 5. Daily mean vapor pressure computed from hourly averaged values for $(A) 1990$ and $(B) 1991$ for study site near Beatty, Nev. 
A.

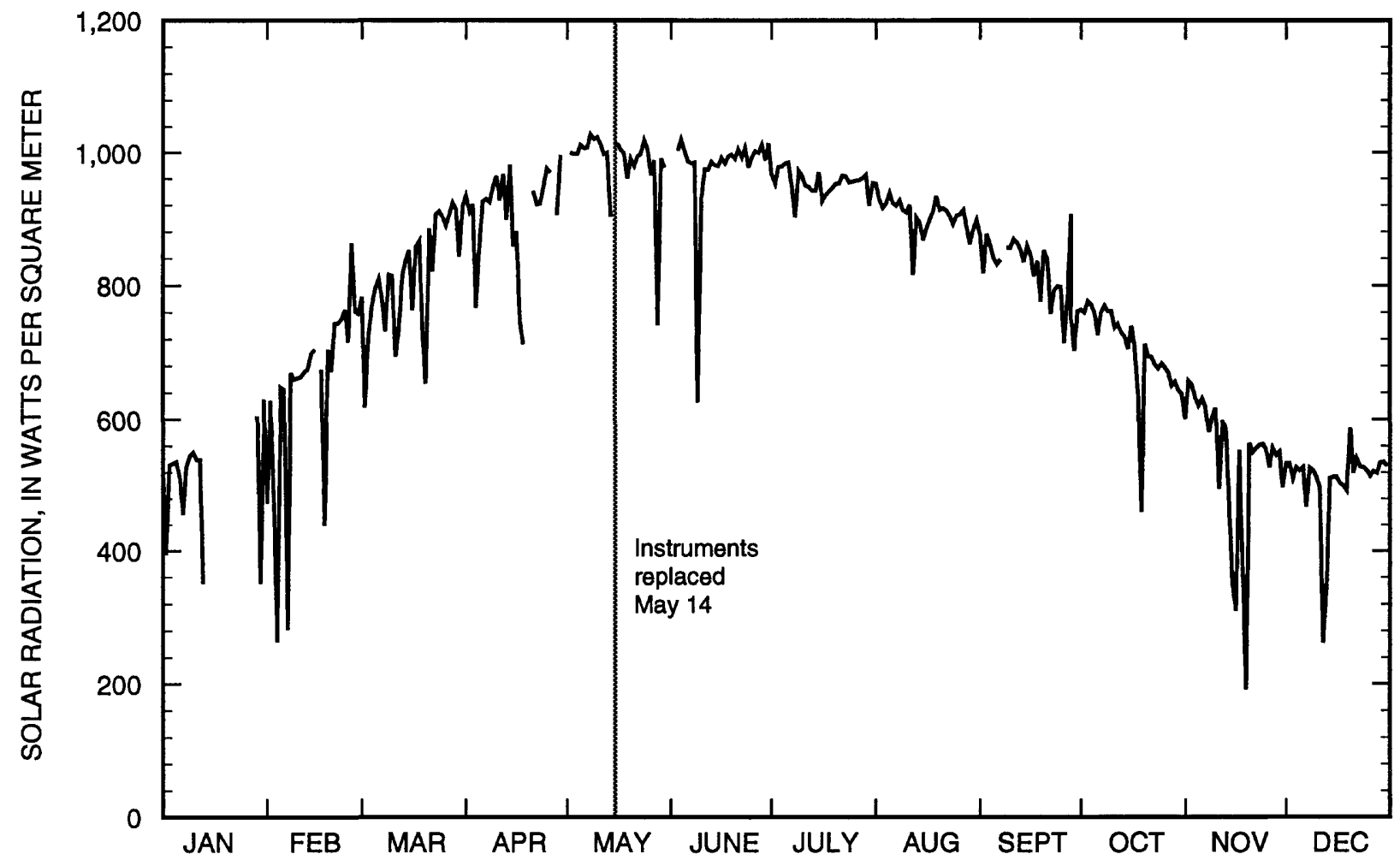

B.

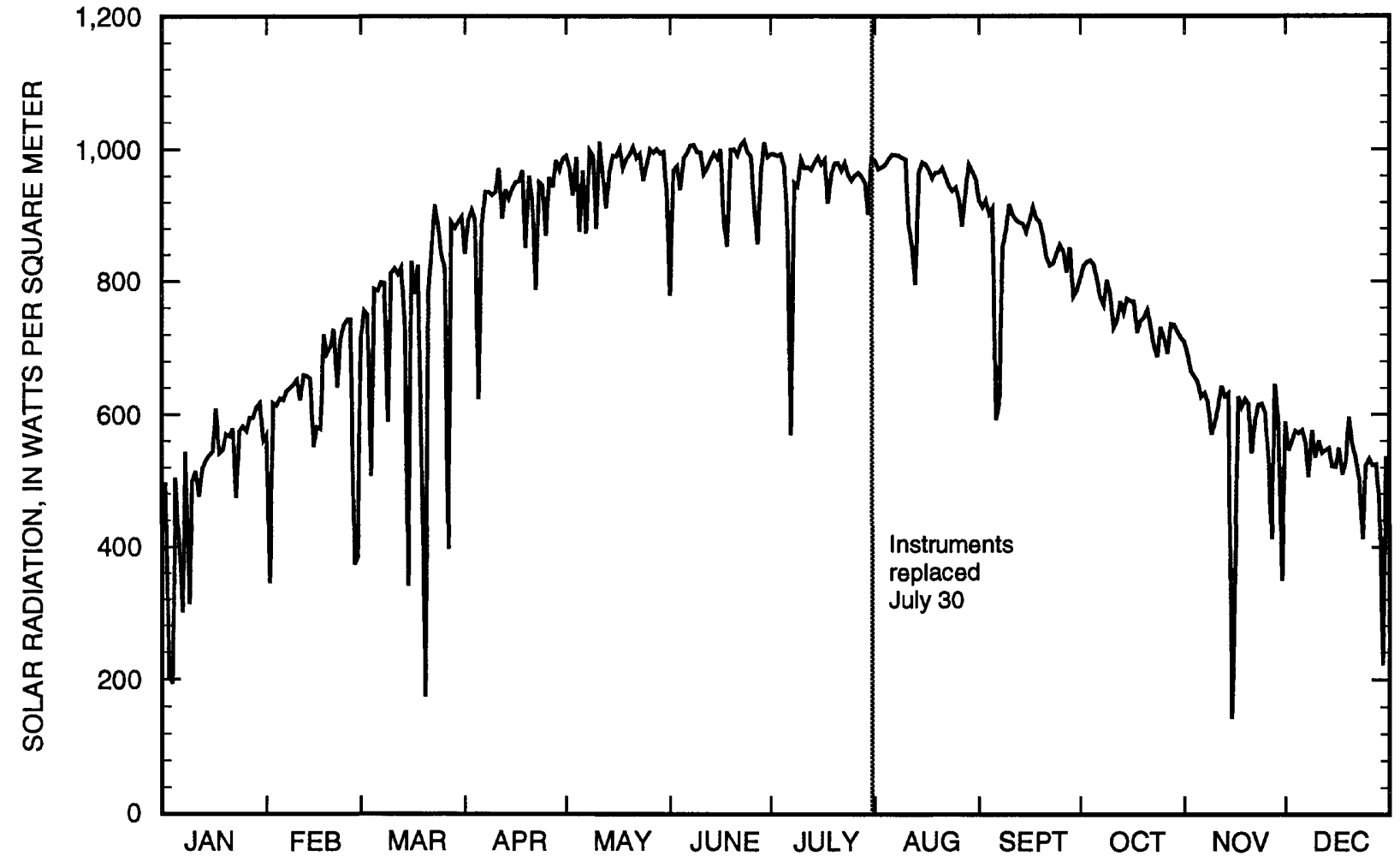

Figure 6. Daily maximum solar radiation computed from hourly averaged values for $(A) 1990$ and $(B) 1991$ for study site near Beatty, Nev. 


\section{Windspeed and Wind-Vector Direction}

Daily mean, maximum, and minimum values of windspeed computed from hourly averaged values are listed in table 3. Daily mean windspeeds are shown in figure 7. In 1990, daily mean windspeeds, for days with 24 values, ranged from less than $1 \mathrm{~m} / \mathrm{s}$ on several days in March and April, to $8.7 \mathrm{~m} / \mathrm{s}$ in November. Hourly averages ranged from less than $1 \mathrm{~m} / \mathrm{s}$ (essentially zero) to almost $14 \mathrm{~m} / \mathrm{s}$ on November 26 . In 1991, daily mean windspeeds ranged from $1.2 \mathrm{~m} / \mathrm{s}$ on January 5 , to $8.4 \mathrm{~m} / \mathrm{s}$ May 31 . Hourly averages ranged from less than $1 \mathrm{~m} / \mathrm{s}$ to more than $14 \mathrm{~m} / \mathrm{s}$.

Daily mean wind-vector direction (degrees Azimuth) and wind-vector magnitude (meters per second) presented in table 3 were determined from hourly wind-vector direction and magnitude values using the following equations (Campbell Scientific, Inc., 1984, p. B-6 to B-10):

Daily mean wind-vector direction in degrees $=\arctan (\bar{x} / \bar{y})$, and

Daily mean wind-vector magnitude

$$
=\sqrt{\overline{\mathrm{x}}^{2}+\overline{\mathrm{y}}^{2}} \text {, }
$$

where $\bar{x}$ is the sum of each hourly wind-vector magnitude multiplied by the sine of the hourly wind-vector direction and divided by the number of hourly values. $\bar{x}$ is positive to the east.

$\bar{y}$ is the sum of each hourly wind-vector magnitude multiplied by the cosine of the hourly wind-vector direction and divided by the number of hourly values. $\bar{y}$ is positive to the north.

Daily mean wind-vector direction (table 3 ) ranges from 0 to 360 degrees Azimuth (increasing degrees clockwise from north). The wind-vector direction calculated from equation 2 was transformed into degrees Azimuth on the basis of $\bar{x}$ and $\bar{y}$. For positive $\bar{x}$ and $\bar{y}$, the value calculated from equation 2 is the daily mean wind-vector direction in degrees Azimuth. For negative values of $\bar{y}$, the calculated value of windvector direction is added to 180 degrees, and for negative values of $\bar{x}$ and positive value of $\bar{y}$, the calculated value is added to 360 degrees. Because equation 2 cannot be used when $\bar{y}$ is zero, the mean wind-vector direction was set to 90 degrees Azimuth for positive values of $\bar{x}$ and 270 degrees Azimuth for negative values of $\bar{x}$.

Daily trends indicate definite interseasonal variability and yearly recurrance patterns in wind direction for 1990 and 1991 . Wind at the study site was predominantly from the northwest during January and February. Northwest winds also prevailed during March, April, and May, but with a somewhat larger proportion coming from the southwest and southeast. Winds in June, July, and August were more evenly distributed from the northwest, southwest, and southeast directions. Winds changed again in September, and northwesterly patterns predominated during the remainder of both years. Wind direction data indicate an almost total lack of wind from the north and northeast at the study site.

\section{Barometric Pressure}

A CSI SBP270 barometric pressure sensor was added to the meteorological station in the summer of 1990. Twenty-minute pressure values were collected between June 2 and December 31, 1990; 10-minute values were collected during 1991 . Barometric pressure at the site was corrected to sea level by using a correction factor $(P)$ in the formula (Campbell Scientific, Inc., 1989):

$P=m v \times 1.2+800+\left[1-\left(1-\frac{\text { altitude }}{44307.69}^{5.253}\right],(4)\right.$

where $m v$ is millivolt output of barometer,

1.2 is barometer multiplier,

800 is barometer offset,

altitude is in meters above sea level, and

$P$ is output in millibars and is multiplied by 0.1 to obtain kilopascals.

Daily mean, maximum, and minimum values of barometric pressure measured during 1990 and 1991 are listed in table 4 . Daily mean barometric pressure values are shown in figure 8 . In 1990, the minimum barometric pressure measured was $99.47 \mathrm{kPa}$ on December 19, and the maximum was $103.12 \mathrm{kPa}$ on November 28. In 1991, the minimum barometric pressure measured was $99.52 \mathrm{kPa}$ on March 1, and the maximum was $103.40 \mathrm{kPa}$ on November 23 . 
A.

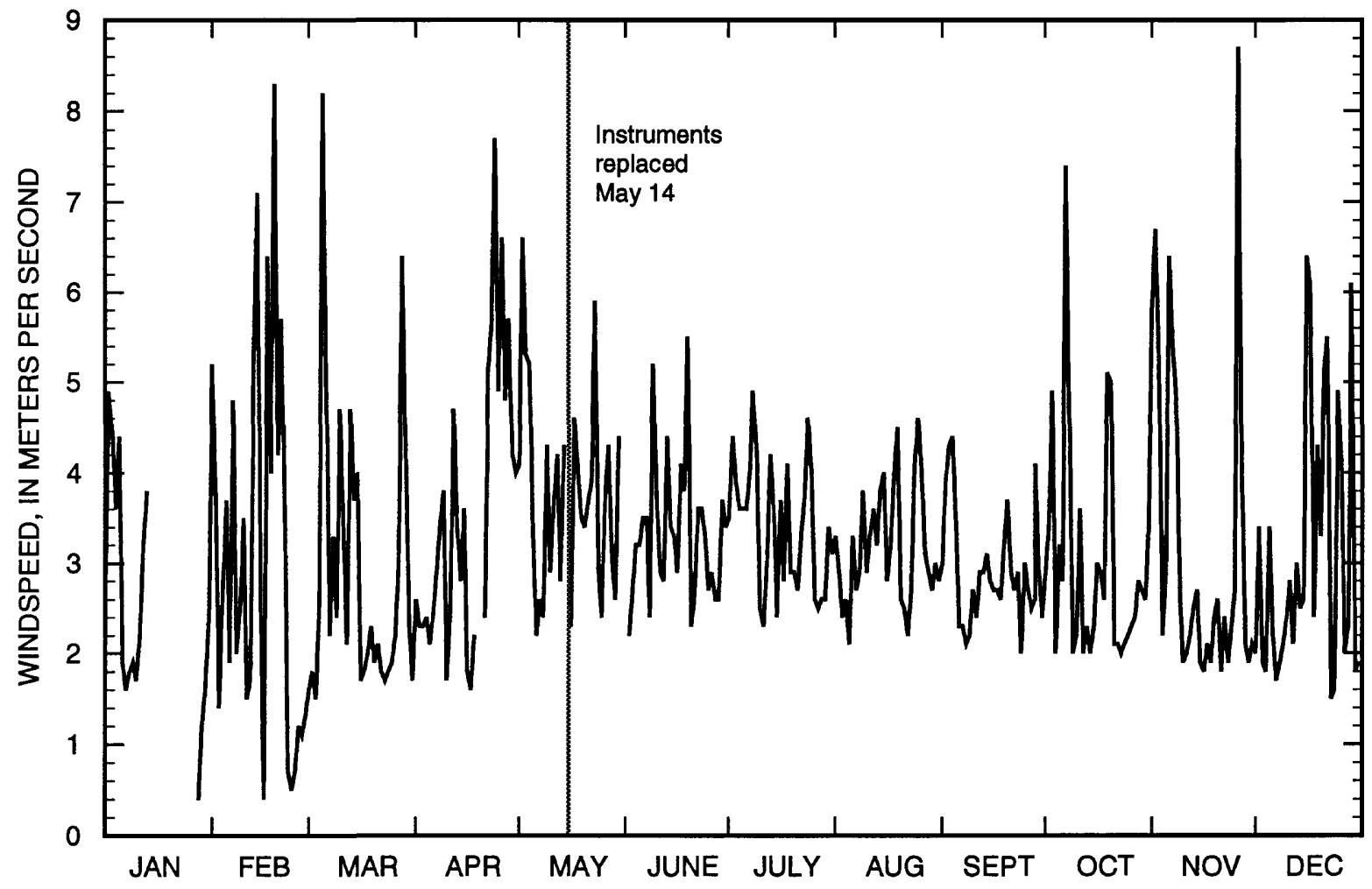

B.

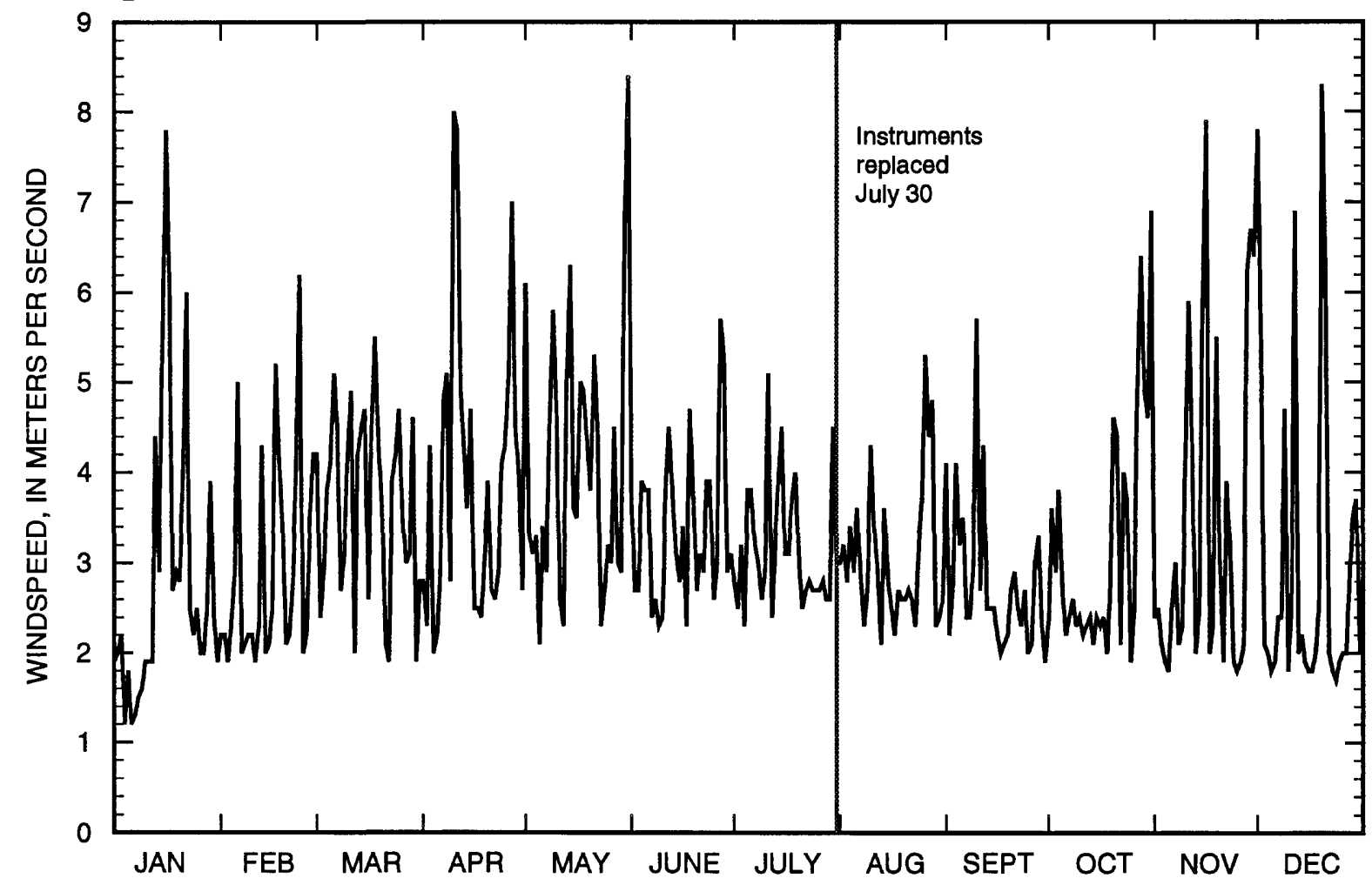

Figure 7. Daily mean windspeed computed from hourly averaged values for (A) 1990 and (B) 1991 for study site near Beatty, Nev. 
A.

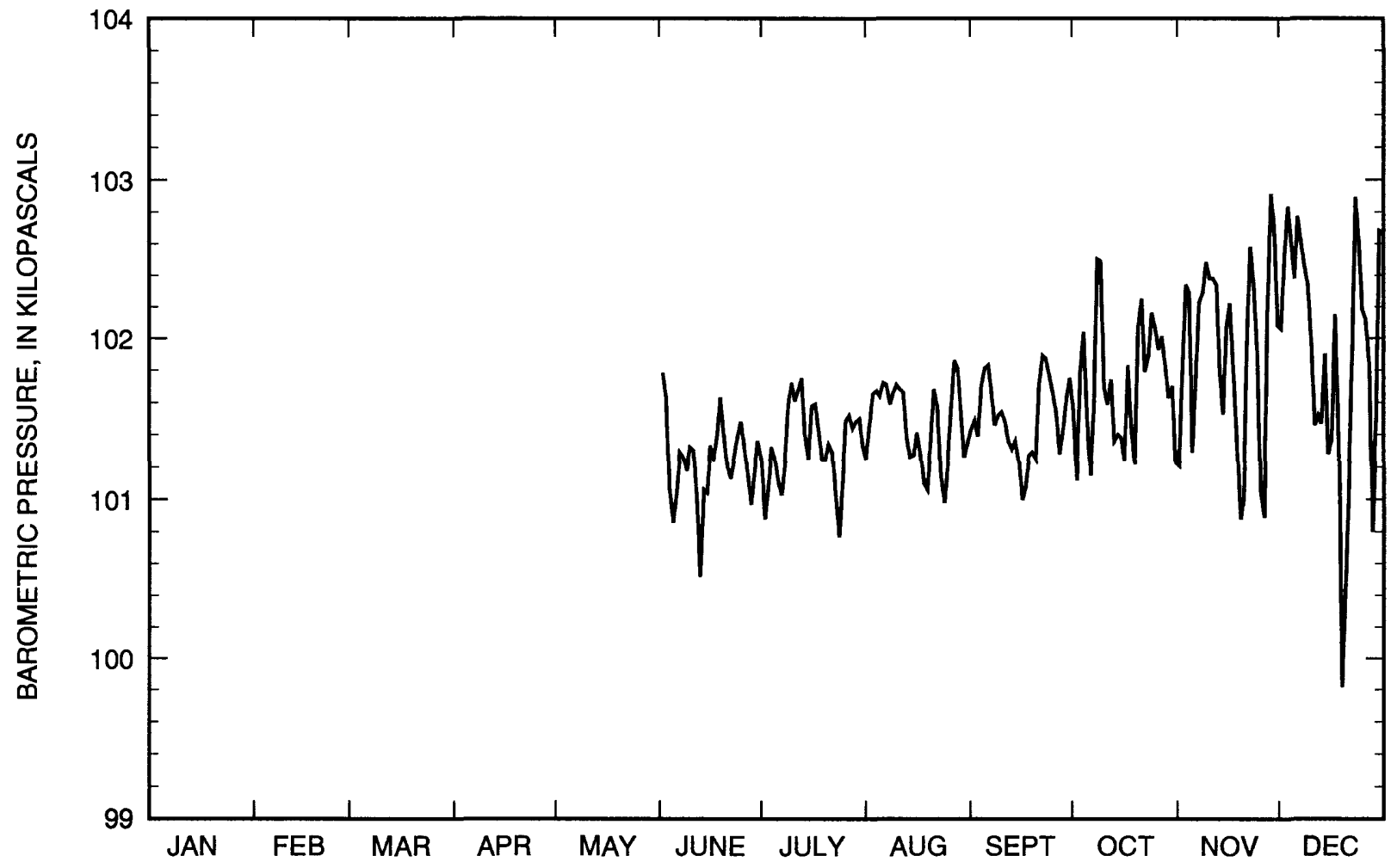

B.

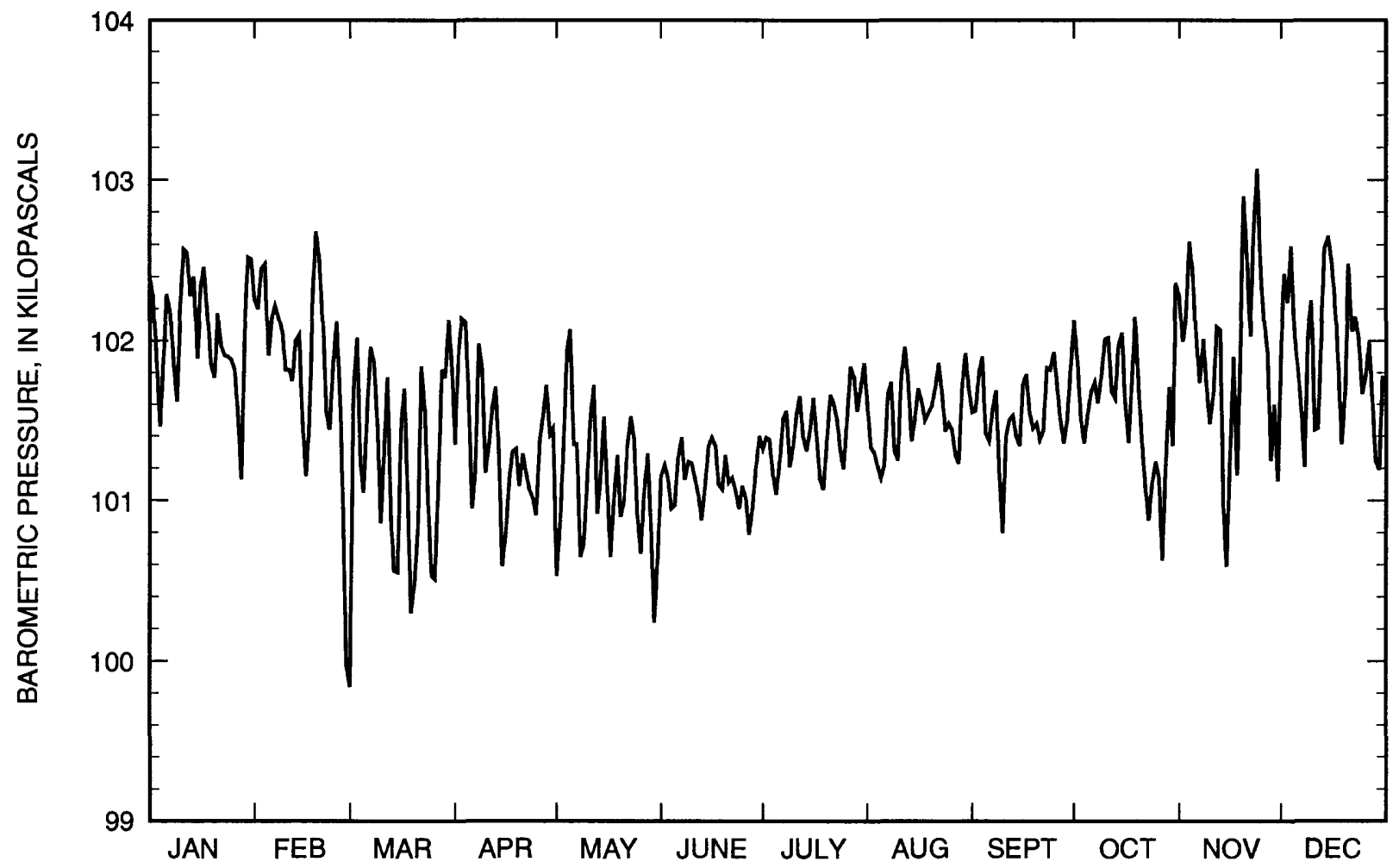

Figure 8. Daily mean barometric pressure computed from $(A)$ 20-minute averaged values for June through December 1990 and (B) 10-minute averaged values for 1991, for study site near Beatty, Nev. 


\section{Precipitation}

Due to the infrequent nature of precipitation at the study site, precipitation is not included in table 3 , but is summarized in table 2 and figures 9 and 10 . Total measured precipitation was $32.4 \mathrm{~mm}$ in 1990 and $103.6 \mathrm{~mm}$ in 1991. Summer precipitation was from localized convective storms, whereas winter events were from regional frontal systems.

Monthly precipitation values for 1990 measured at the study site are shown in figure $9 \mathrm{~A}$. Monthly precipitation ranged from $14.3 \mathrm{~mm}$ in September to zero in February, August, and December. More than 70 percent of the precipitation occurred in January $(9.3 \mathrm{~mm})$ and September $(14.3 \mathrm{~mm})$.

Monthly precipitation values for 1991 at the study site are shown in figure $10 \mathrm{~A}$. Monthly precipitation ranged from $59.4 \mathrm{~mm}$ in March to zero in January, April, June, October, and November. More than 70 percent of the precipitation occurred the last 2 days of February and during March.

Figures $9 B$ and $10 B$ show monthly precipitation at the study site (altitude $847 \mathrm{~m}$ ) and two National Oceanic and Atmospheric Administration (NOAA) sites. One of the these sites is designated Beatty $8 \mathrm{~N}$ (lat. $37^{\circ} 00^{\prime} \mathrm{N}$., long. $116^{\circ} 43^{\prime} \mathrm{W}$.) and is situated $12.9 \mathrm{~km}$ north of Beatty at an altitude of $1,007 \mathrm{~m}$ (fig. 1); the other is Amargosa Farms (lat. $36^{\circ} 34^{\prime}$ N., long. $116^{\circ} 28^{\prime} \mathrm{W}$.), which is about $35 \mathrm{~km}$ southeast of the study site at an altitude of $747 \mathrm{~m}$. Monthly values differ considerably between sites.

Daily precipitation totals for the study site are shown in figures 9 and 10. Values for both years are tabulated in table 2 . The largest events occurred during the fall and spring months. In 1990, daily precipitation exceeded 5 mm only on September 21 and 23. In 1991, daily precipitation exceeded $10 \mathrm{~mm}$ only on March 20 , 21 , and 27 . Summer storms are usually of short duration, but can be intense.

\section{SUMMARY}

Meteorological data were collected adjacent to a low-level radioactive-waste facility near Beatty, Nev., for calendar years 1990 and 1991 in support of an ongoing study to estimate the potential for downward movement of radionuclides into the unsaturated sediments beneath waste-burial trenches at the facility.
Table 2. Daily total precipitation at study site near Beatty, Nev., for 1990 and 1991. All unlisted dates had no precipitation

[Values are in millimeters.]

\begin{tabular}{|c|c|c|}
\hline \multicolumn{3}{|c|}{1990} \\
\hline Month & Day & $\begin{array}{c}\text { Total } \\
\text { precipitation }\end{array}$ \\
\hline $\begin{array}{l}\text { January } \\
\text { January } \\
\text { January } \\
\text { January } \\
\text { January }\end{array}$ & $\begin{array}{r}2 \\
4 \\
16 \\
17 \\
18\end{array}$ & $\begin{array}{r}0.8 \\
.8 \\
1.0 \\
5.0 \\
1.7\end{array}$ \\
\hline $\begin{array}{l}\text { March } \\
\text { March }\end{array}$ & $\begin{array}{l}5 \\
6\end{array}$ & $\begin{array}{l}.5 \\
.3\end{array}$ \\
\hline April & 16 & .5 \\
\hline $\begin{array}{l}\text { May } \\
\text { May }\end{array}$ & $\begin{array}{l}27 \\
28\end{array}$ & $\begin{array}{l}2.0 \\
1.3\end{array}$ \\
\hline June & 9 & .3 \\
\hline $\begin{array}{l}\text { July } \\
\text { July }\end{array}$ & $\begin{array}{l}14 \\
17\end{array}$ & $\begin{array}{r}2.0 \\
.3\end{array}$ \\
\hline $\begin{array}{l}\text { September } \\
\text { September } \\
\text { September } \\
\text { September }\end{array}$ & $\begin{array}{l}21 \\
23 \\
28 \\
29\end{array}$ & $\begin{array}{r}5.8 \\
6.9 \\
.8 \\
.8\end{array}$ \\
\hline October & 18 & .3 \\
\hline $\begin{array}{l}\text { November } \\
\text { November }\end{array}$ & $\begin{array}{l}19 \\
20\end{array}$ & $\begin{array}{l}.5 \\
.8\end{array}$ \\
\hline \multicolumn{3}{|c|}{1991} \\
\hline $\begin{array}{l}\text { February } \\
\text { February }\end{array}$ & $\begin{array}{l}27 \\
28\end{array}$ & $\begin{array}{l}6.1 \\
9.6\end{array}$ \\
\hline $\begin{array}{l}\text { March } \\
\text { March } \\
\text { March } \\
\text { March } \\
\text { March } \\
\text { March } \\
\text { March }\end{array}$ & $\begin{array}{r}1 \\
13 \\
19 \\
20 \\
21 \\
26 \\
27\end{array}$ & $\begin{array}{r}4.8 \\
4.8 \\
6.1 \\
13.0 \\
10.2 \\
8.1 \\
12.4\end{array}$ \\
\hline May & 2 & 1.0 \\
\hline $\begin{array}{l}\text { July } \\
\text { July } \\
\text { July } \\
\text { July }\end{array}$ & $\begin{array}{r}7 \\
8 \\
30 \\
31\end{array}$ & $\begin{array}{r}.5 \\
3.8 \\
5.8 \\
.8\end{array}$ \\
\hline $\begin{array}{l}\text { August } \\
\text { August }\end{array}$ & $\begin{array}{l}10 \\
12\end{array}$ & $\begin{array}{l}1.5 \\
1.0\end{array}$ \\
\hline $\begin{array}{l}\text { September } \\
\text { September }\end{array}$ & $\begin{array}{r}5 \\
28\end{array}$ & $\begin{array}{r}2.3 \\
.8\end{array}$ \\
\hline $\begin{array}{l}\text { December } \\
\text { December } \\
\text { December } \\
\text { December } \\
\text { December }\end{array}$ & $\begin{array}{r}7 \\
8 \\
19 \\
29 \\
30\end{array}$ & $\begin{array}{r}.8 \\
1.0 \\
5.1 \\
.8 \\
3.3\end{array}$ \\
\hline
\end{tabular}




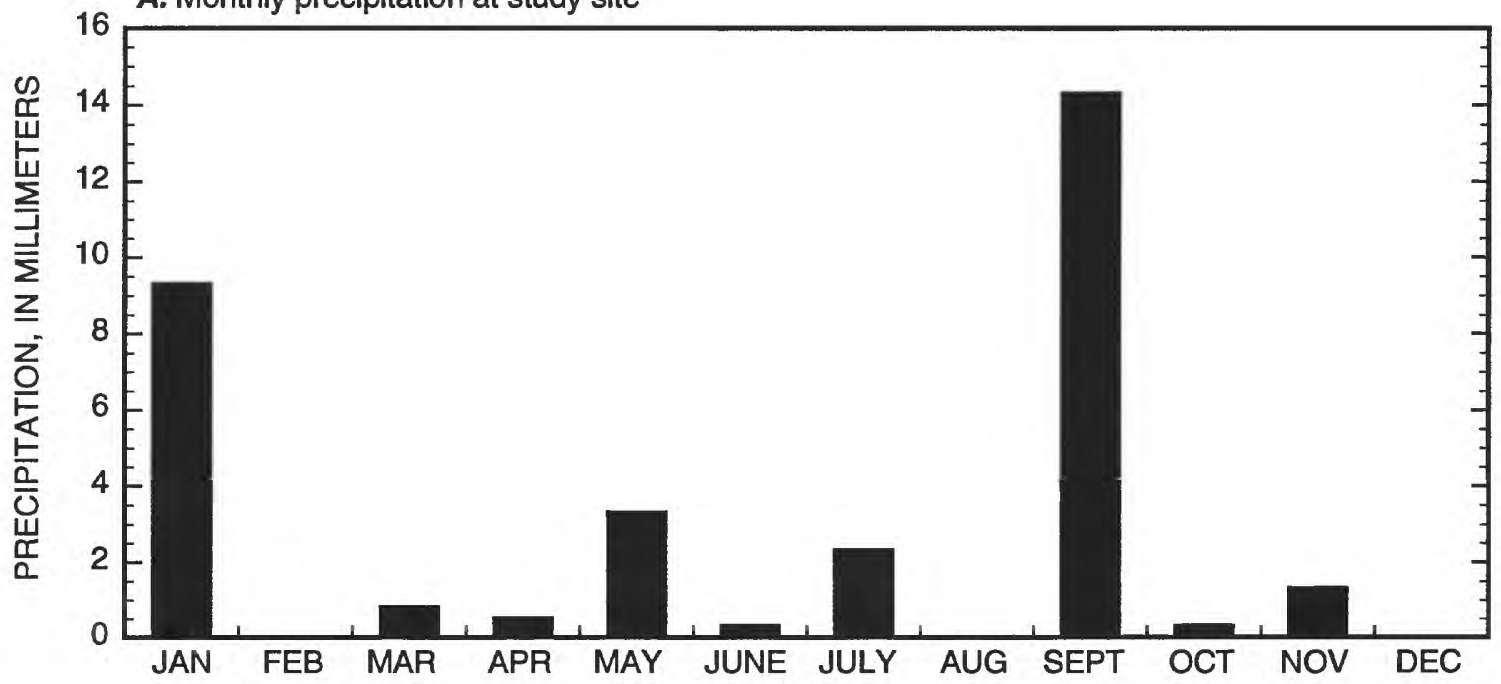

B. Monthly precipitation at three sites

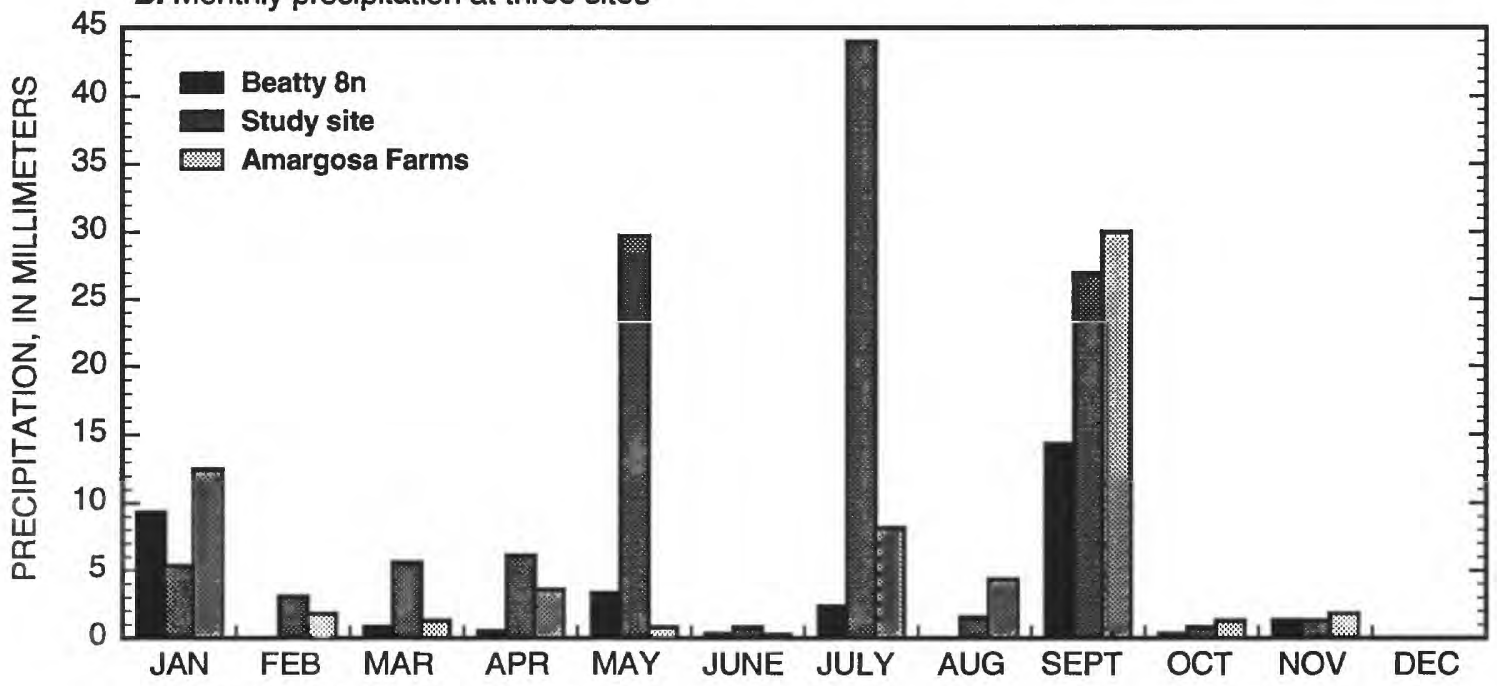

C. Daily precipitation at study site

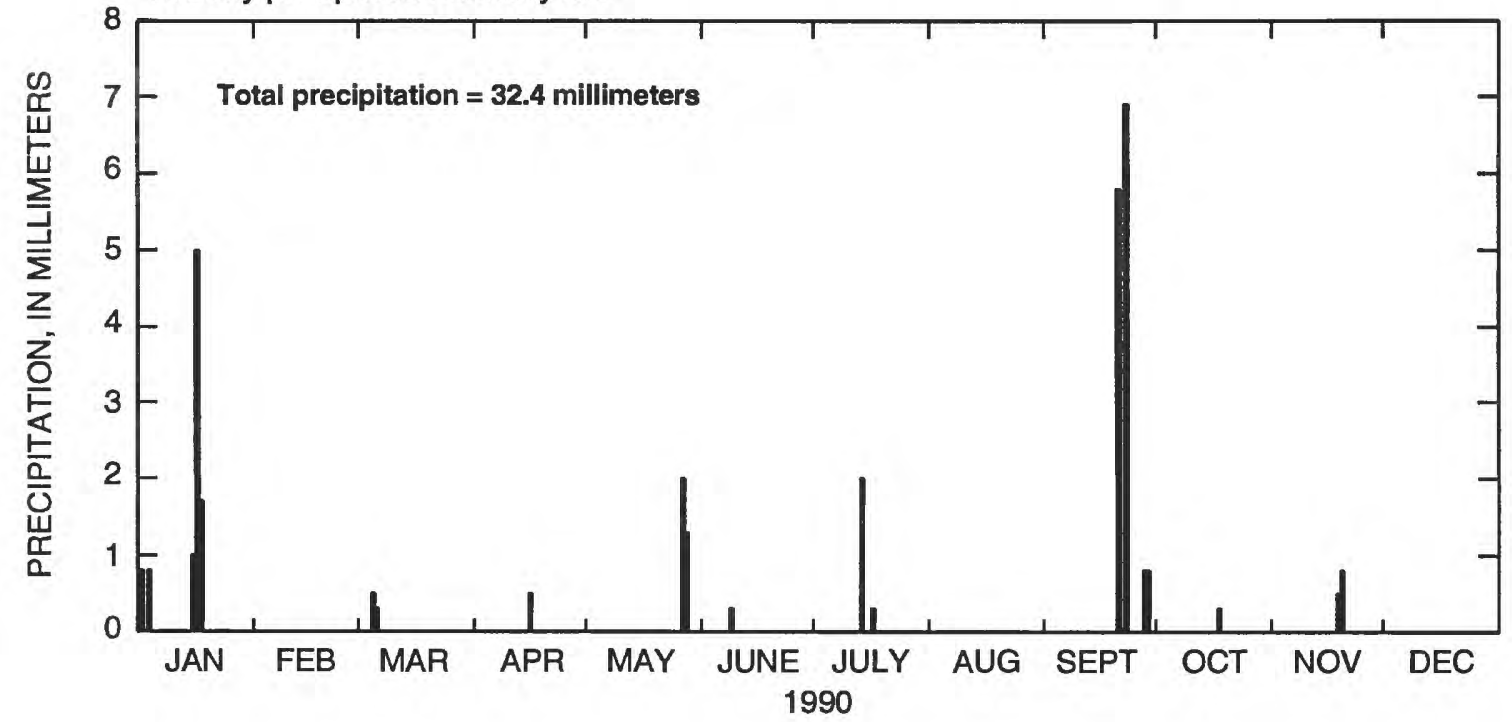

Figure 9. Precipitation at study site near Beatty, Nev., and two nearby sites for 1990. 


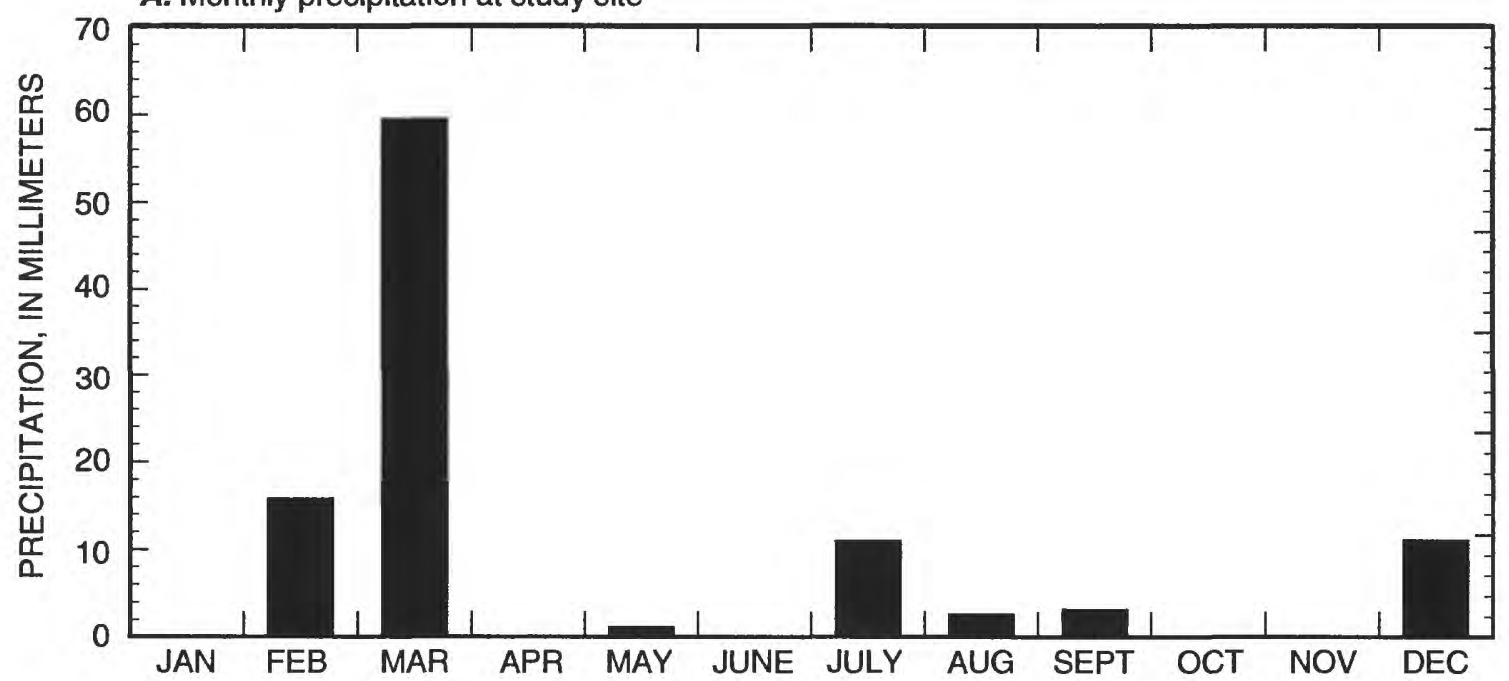

B. Monthly precipitation at three sites

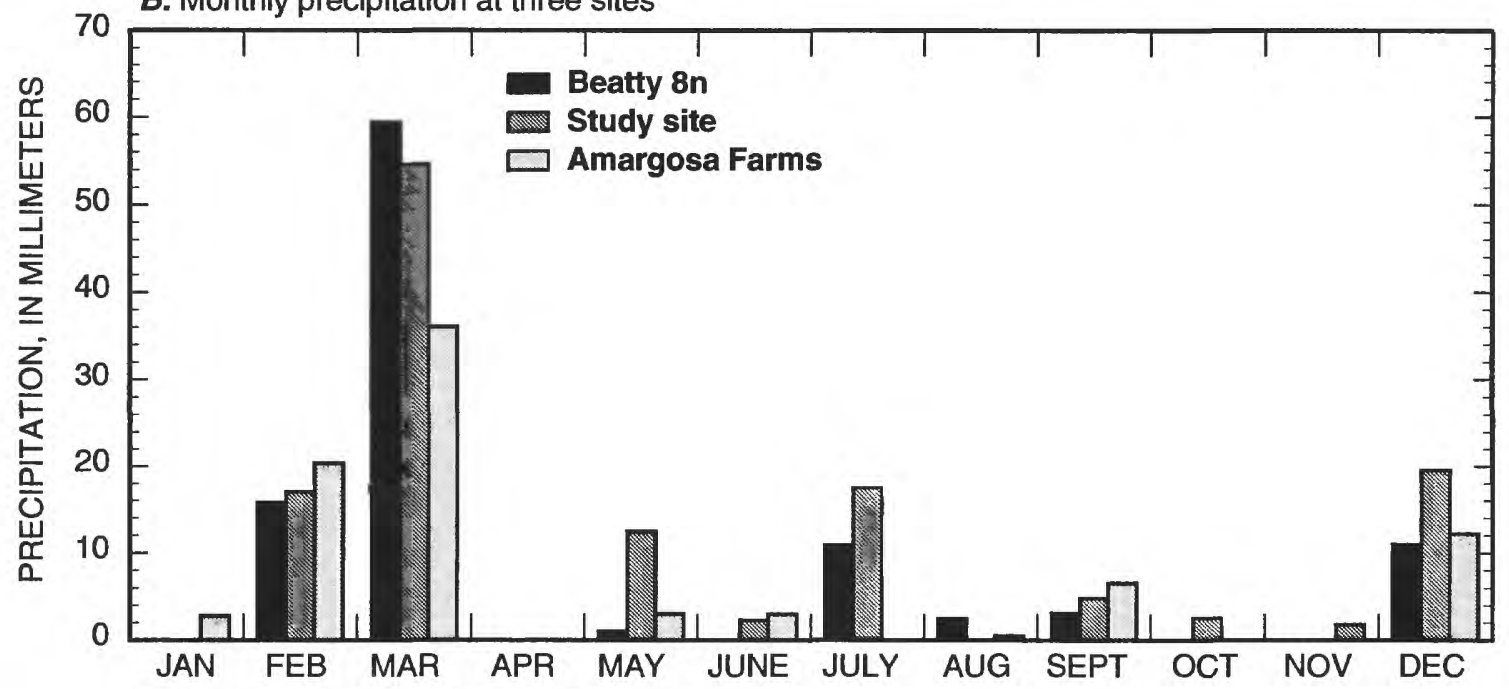

C. Daily precipitation at study site

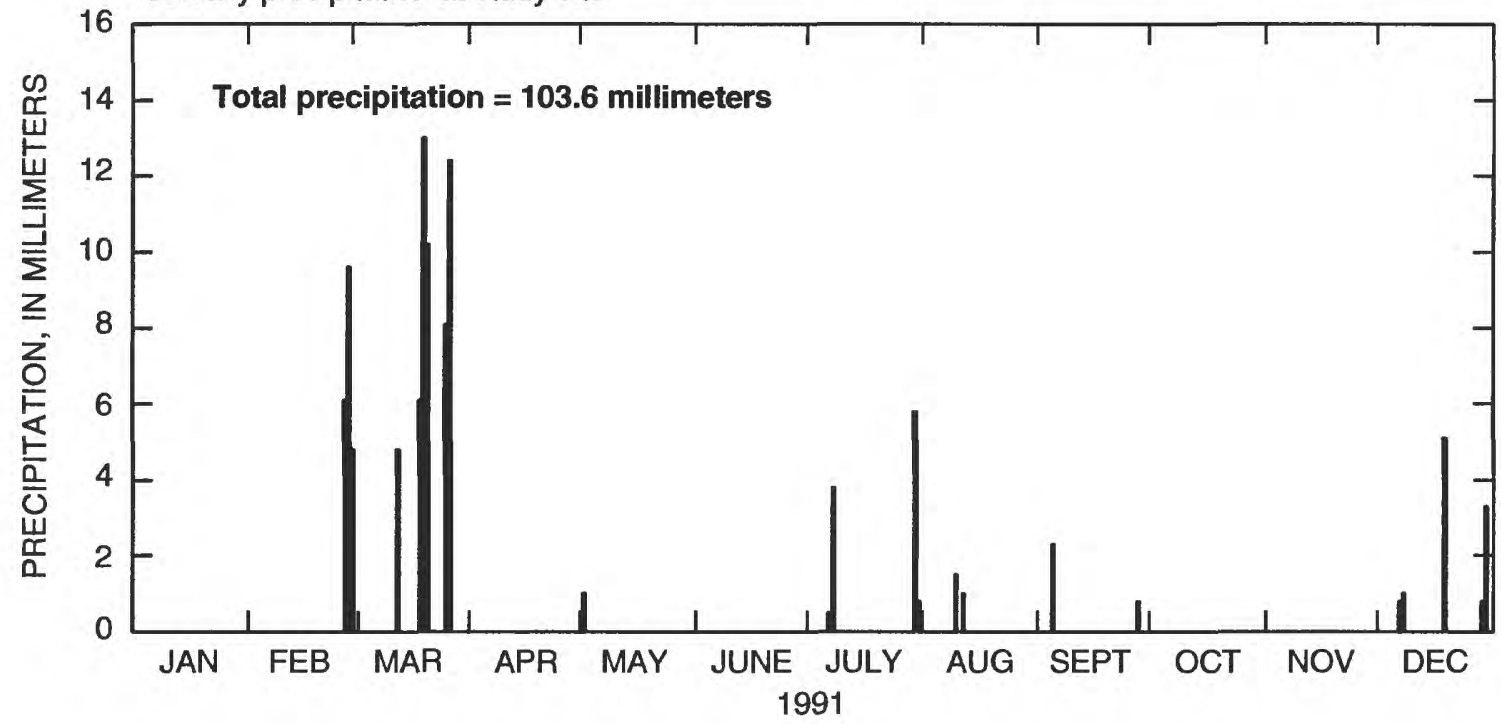

Figure 10. Precipitation at study site near Beatty, Nev., and two nearby sites for 1991. 
This report provides daily averaged values of air temperature, relative humidity, vapor pressure, incident solar radiation, windspeed, wind direction, and barometric pressure, and daily totals of precipitation. A general description of instrumentation used and sensor installation is given.

In 1990, the minimum hourly averaged air temperature for the year was $-16.2^{\circ} \mathrm{C}$ in December and the maximum was $44.2^{\circ} \mathrm{C}$ in July. Hourly averaged values for relative humidity ranged from 6 percent in June, July, and August to more than 90 percent in September. Hourly vapor pressures ranged from a minimum of $0.08 \mathrm{kPa}$ in February to a maximum of $1.84 \mathrm{kPa}$ in July. Daily maximum solar radiation values ranged from $192 \mathrm{~W} / \mathrm{m}^{2}$ in November to $1,028 \mathrm{~W} / \mathrm{m}^{2}$ in May. Mean daily windspeed ranged from less than $1 \mathrm{~m} / \mathrm{s}$ (essentially zero) on several days to $8.7 \mathrm{~m} / \mathrm{s}$ in November. Wind direction determined from hourly averaged data was predominantly from the northwest from January through March and from October through December. The wind shifted during the summer months and was commonly from the southeast and northwest. Hourly barometric pressures ranged from $99.47 \mathrm{kPa}$ in December to $103.12 \mathrm{kPa}$ in November. Total measured precipitation for the year was $32.4 \mathrm{~mm}$. Monthly precipitation ranged from $14.3 \mathrm{~mm}$ in September to zero in February, August, and December. Daily precipitation totaled more than $5 \mathrm{~mm}$ only twice during 1990, both in September.

In 1991, the minimum hourly averaged air temperature for the year was $-9.2^{\circ} \mathrm{C}$ in January and the maximum was $43.7^{\circ} \mathrm{C}$ in July. Hourly averaged values for relative humidity ranged from 3 percent in August to more than 95 percent in January and December. Hourly vapor pressures ranged from a minimum of $0.07 \mathrm{kPa}$ in January to a maximum of $2.22 \mathrm{kPa}$ in July. Daily maximum solar radiation values ranged from $143 \mathrm{~W} / \mathrm{m}^{2}$ in November to $1,041 \mathrm{~W} / \mathrm{m}^{2}$ in May. Mean daily windspeed ranged from $1.2 \mathrm{~m} / \mathrm{s}$ in January to $8.4 \mathrm{~m} / \mathrm{s}$ in May. Wind direction determined from hourly averaged data was predominantly from the northwest between January through March and October through December. The wind shifted during the summer months and was commonly from the southeast and northwest. Hourly barometric pressures ranged from $99.52 \mathrm{kPa}$ in March to $103.40 \mathrm{kPa}$ in November. Total measured precipitation for the year was $103.6 \mathrm{~mm}$. Monthly precipitation ranged from $59.4 \mathrm{~mm}$ in March to zero in January, April, June, October, and November. Daily precipitation totaled more than $10 \mathrm{~mm}$ for 3 days in March.

\section{REFERENCES CITED}

Andraski, B.J., 1990, Water movement and trench stability at a simulated arid burial site for low-level radioactive waste: LaGrange, Ill., American Nuclear Society, Proceedings of the Topical Conference on Nuclear Waste Isolation in the Unsaturated Zone, Las Vegas, Nev., September 1989, p. 166-173.

Campbell, G.S., 1986, Introduction to environmental biophysics (3d ed.): New York, Springer-Verlag, 159 p.

Campbell Scientific, Inc., 1984, CR21 micrologger operators manual: Logan, Utah, Campbell Scientific, Inc., Revision No. Im CR21-10, 81 p.

1989, SBP270 Barometric pressure sensor instruction manual: Logan, Utah, Campbell Scientific, Inc., Revision, 4/89, 8 p.

Fischer, J.M., 1992, Sediment properties and water movement through shallow unsaturated alluvium at an arid site for disposal of low-level radioactive waste near Beatty, Nye County, Nevada: U.S. Geological Survey Water-Resources Investigations Report 92-4032, 48 p.

Kunkel, K.E., 1988, Development of standards for automated weather stations continues, in The Tripod: High Plains Regional Climate Center, University of Nebraska, Lincoln, Spring 1988, p. 3-5.

Lowe, P.R., 1977, An approximating polynomial for the computation of saturation vapor pressure: Journal of Applied Meteorology, v. 16, no. 1, p. 100-103.

Nichols, W.D., 1987, Geohydrology of the unsaturated zone at the burial site for low-level radioactive waste near Beatty, Nye County, Nevada: U.S. Geological Survey Water-Supply Paper 2312, $57 \mathrm{p}$.

Wallace, J.M., and Hobbs, P.V., 1977, Atmospheric science, in Introductory survey: New York, Academic Press, p. 59-61.

Wood, J.L., and Andraski, B.J., 1992, Selected meteorological data for an arid site near Beatty, Nevada, Nye County, Nevada, calendar year 1989: U.S. Geological Survey Open-File Report 92-484, 27 p.

Wood, J.L., and Fischer J.M., 1991, Selected meteorological data for an arid site near Beatty, Nevada, Nye County, Nevada, calendar year 1986: U.S. Geological Survey Open-File Report 91-189, 27 p.

1992, Selected meteorological data for an arid site near Beatty, Nevada, Nye County, Nevada, calendar year 1987: U.S. Geological Survey Open-File Report 92-59, $27 \mathrm{p}$.

Wood, J.L., Hill, K.J., and Andraski B.J., 1992, Selected meteorological data for an arid site near Beatty, Nevada, Nye County, Nevada, calendar year 1988: U.S. Geological Survey Open-File Report 92-61, 27 p. 


\section{BASIC DATA}

This section contains tables 3 and 4 . Table 3 is a listing of daily averaged meteorological data (except precipitation, which is totaled) collected at the study site for 1990 and 1991 . Table 4 is a summary of barometric pressure values collected at the study site in 1990 and 1991. 


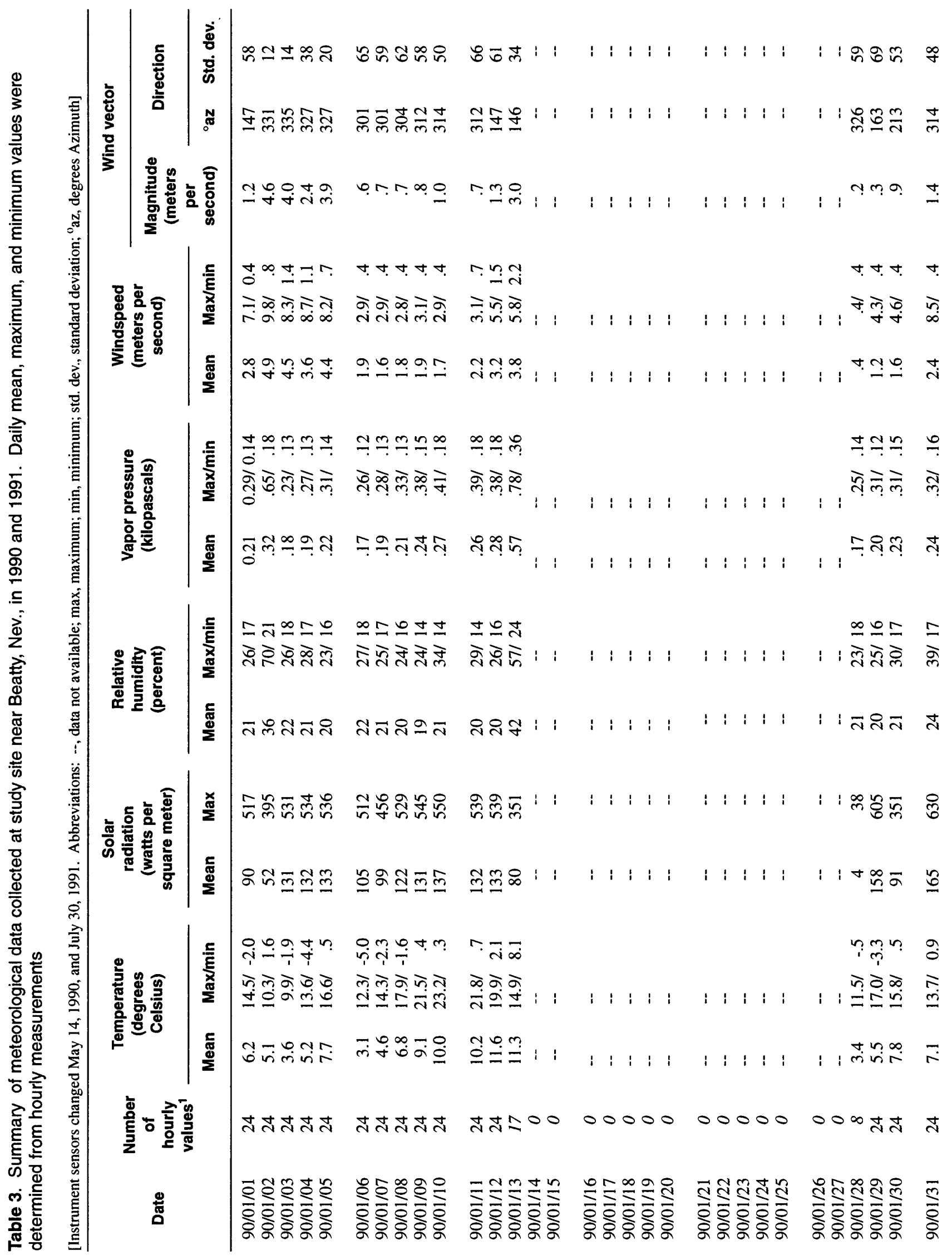




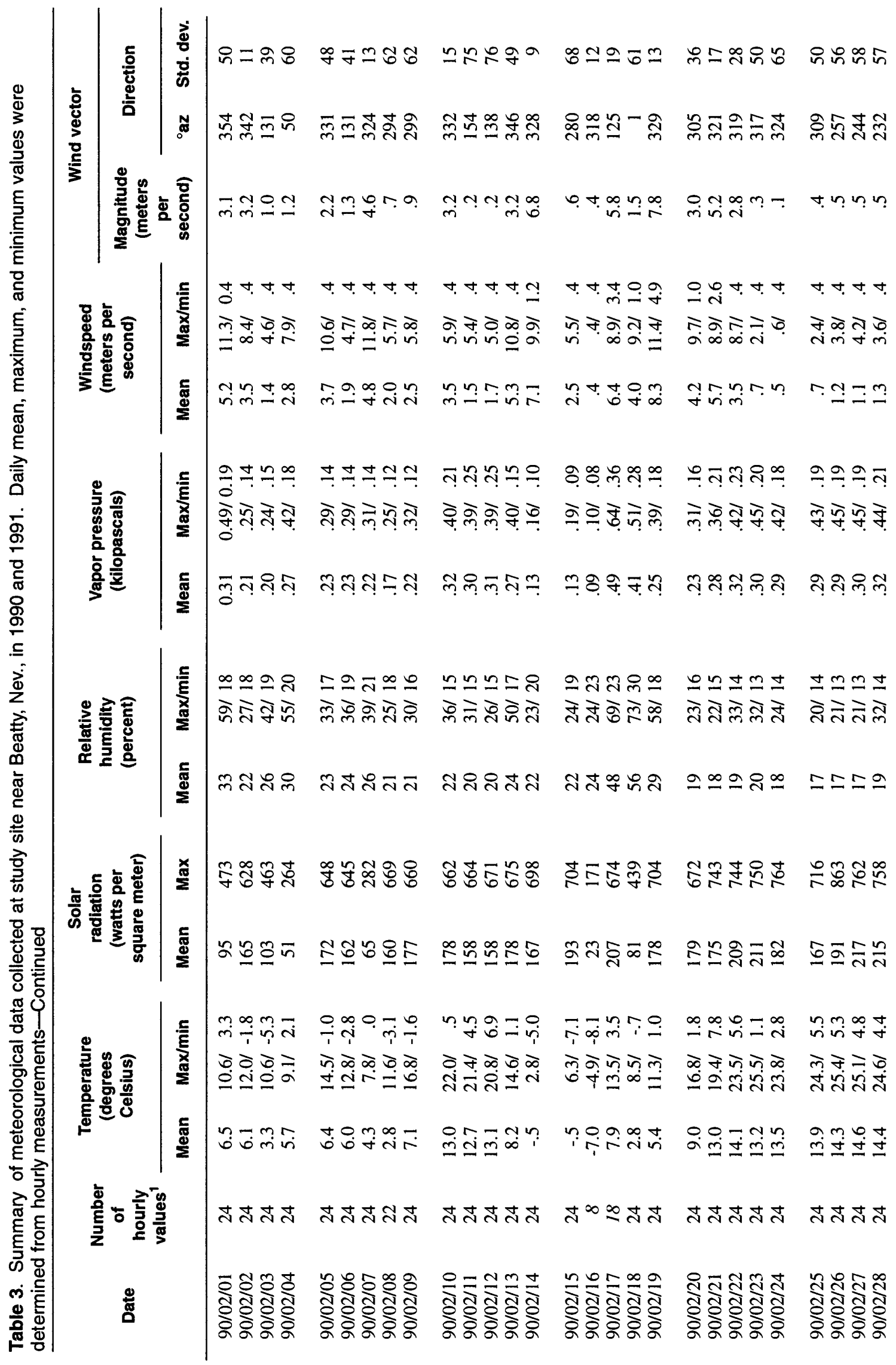




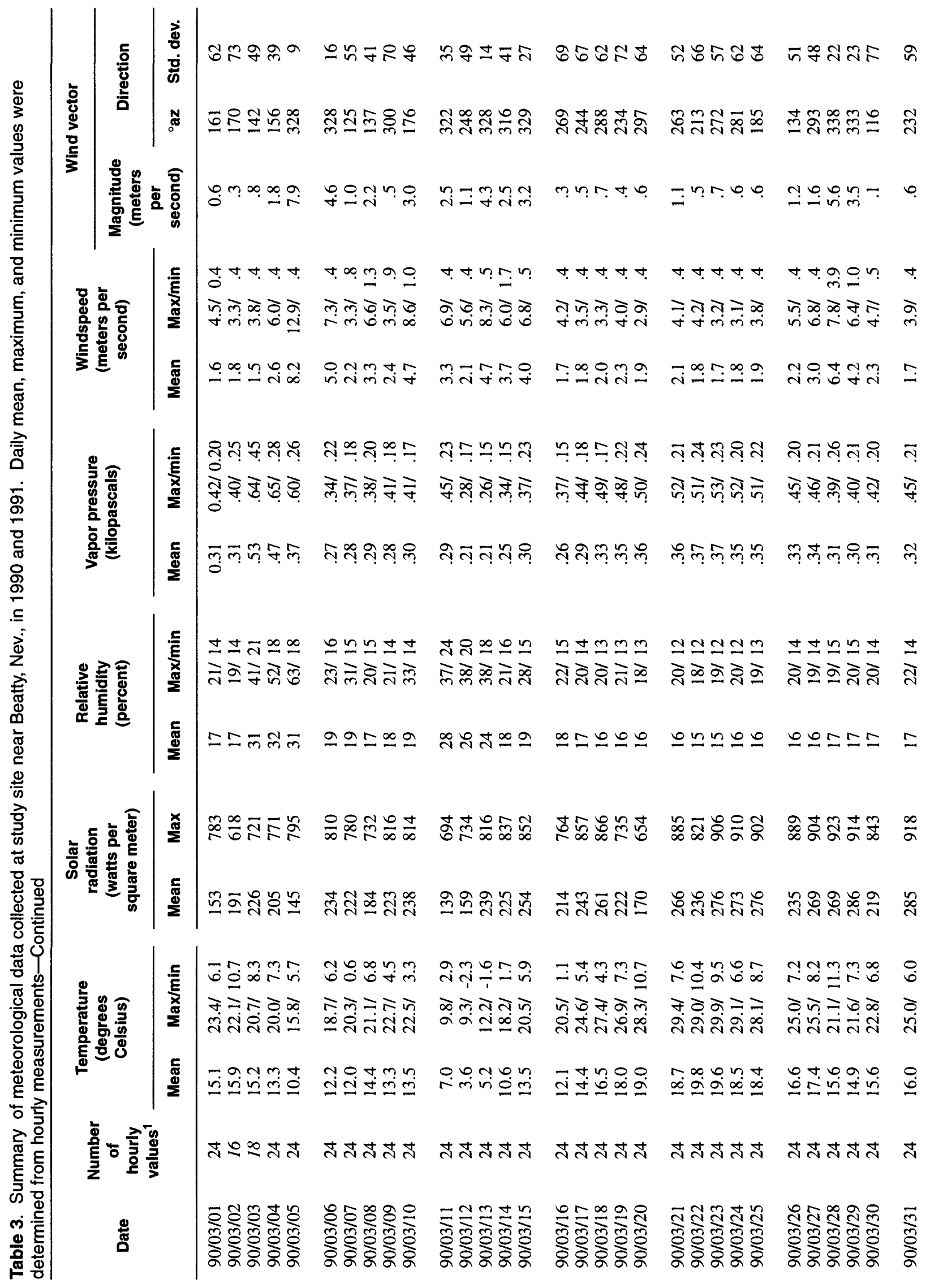




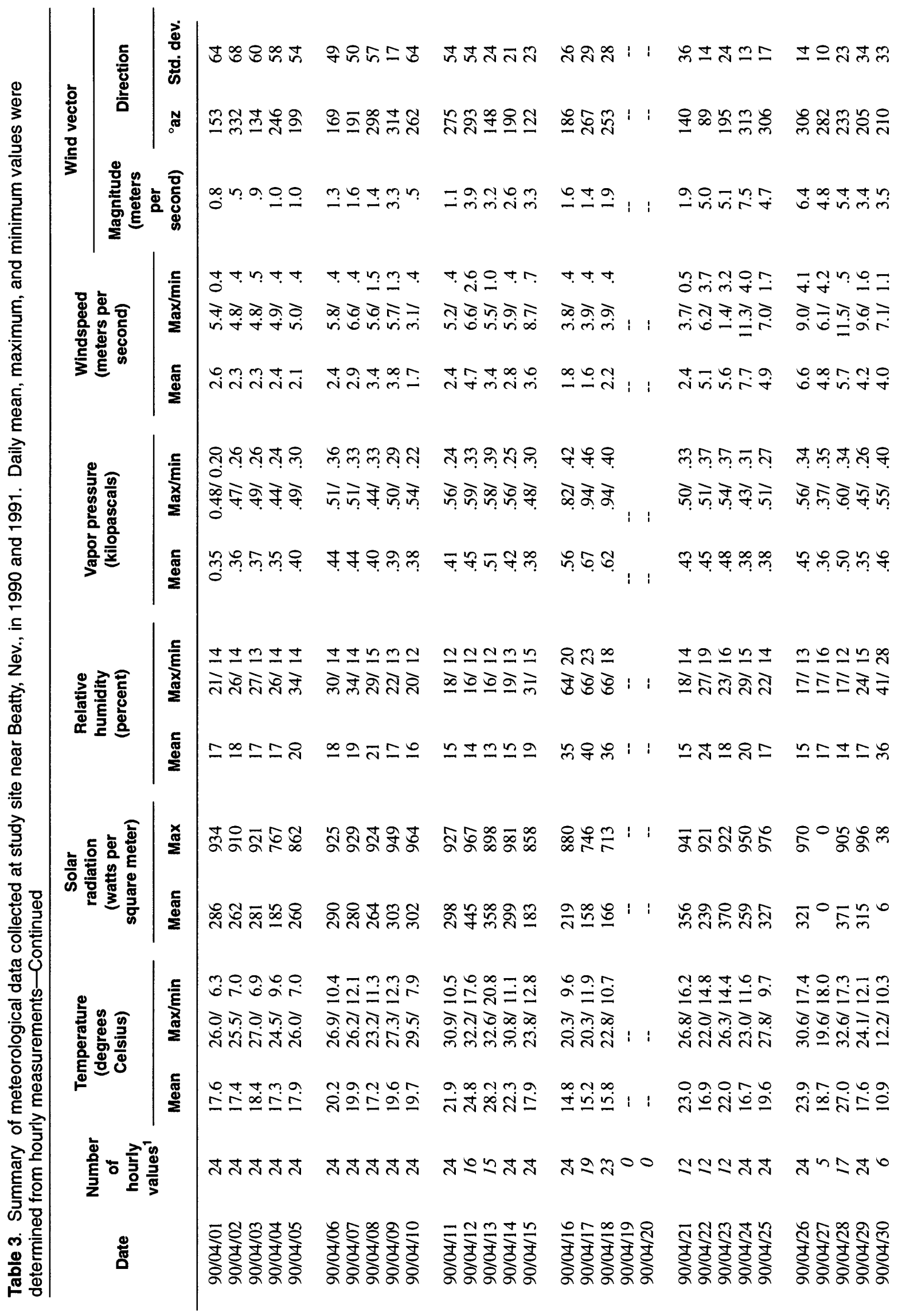




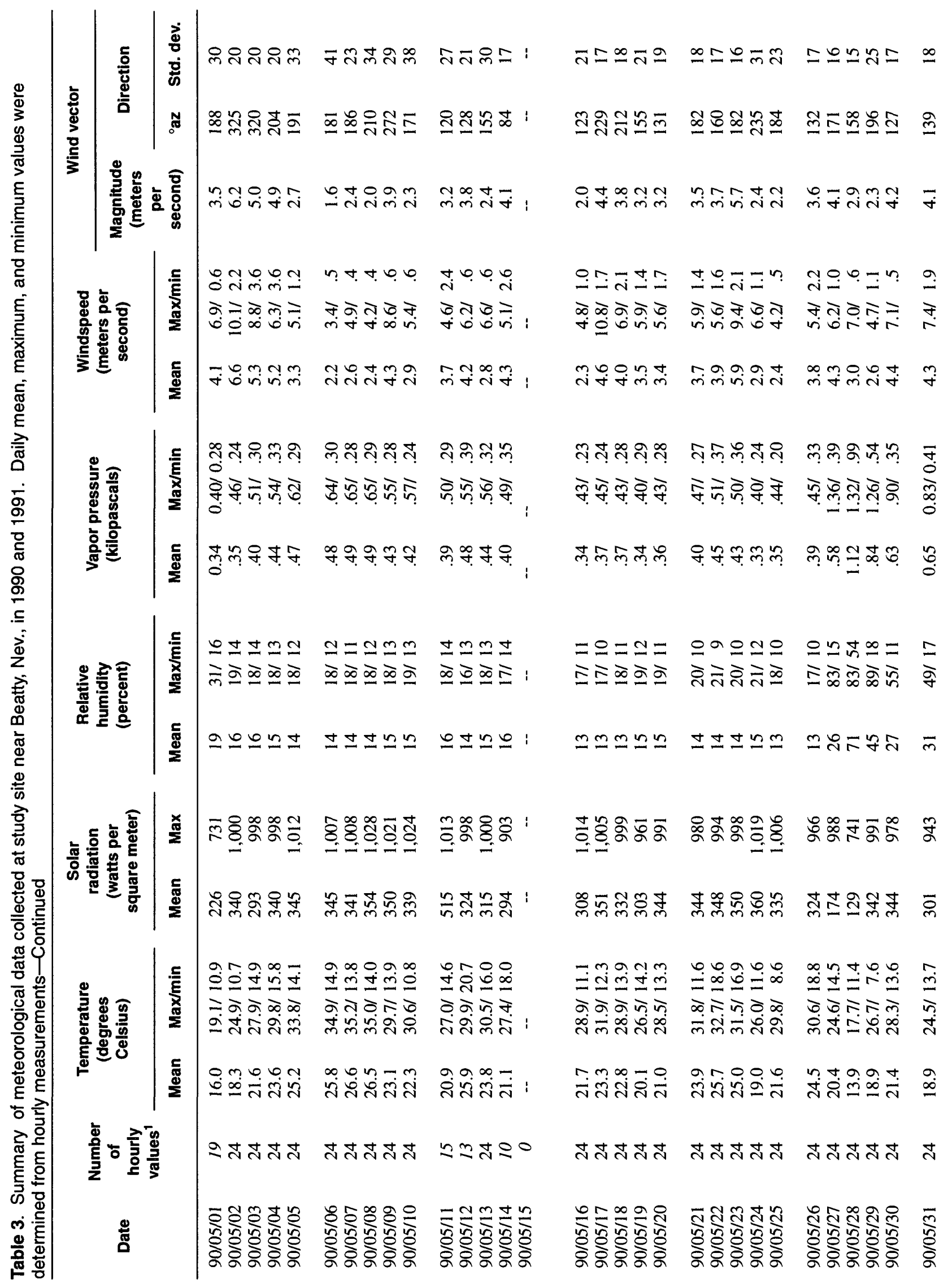




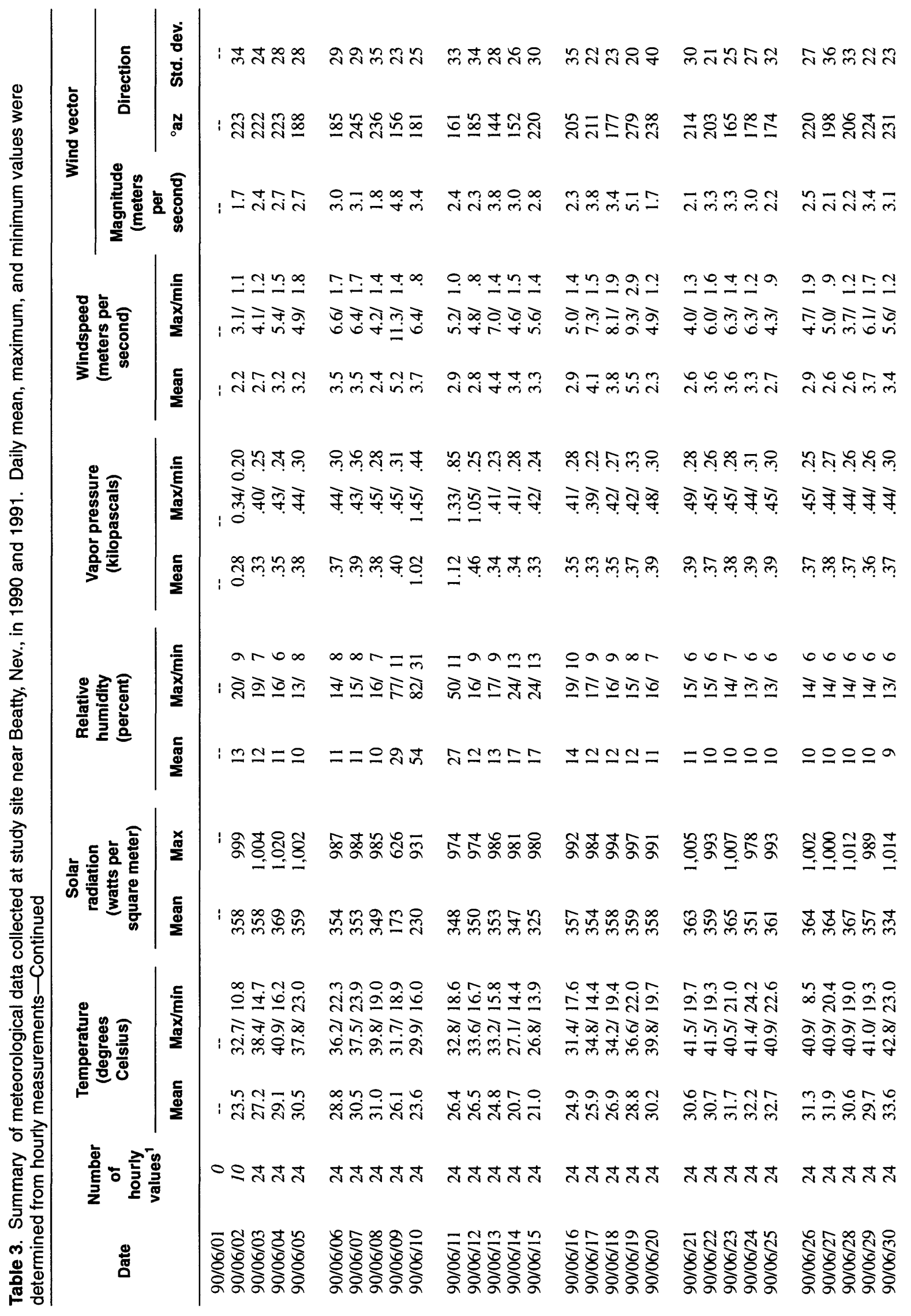




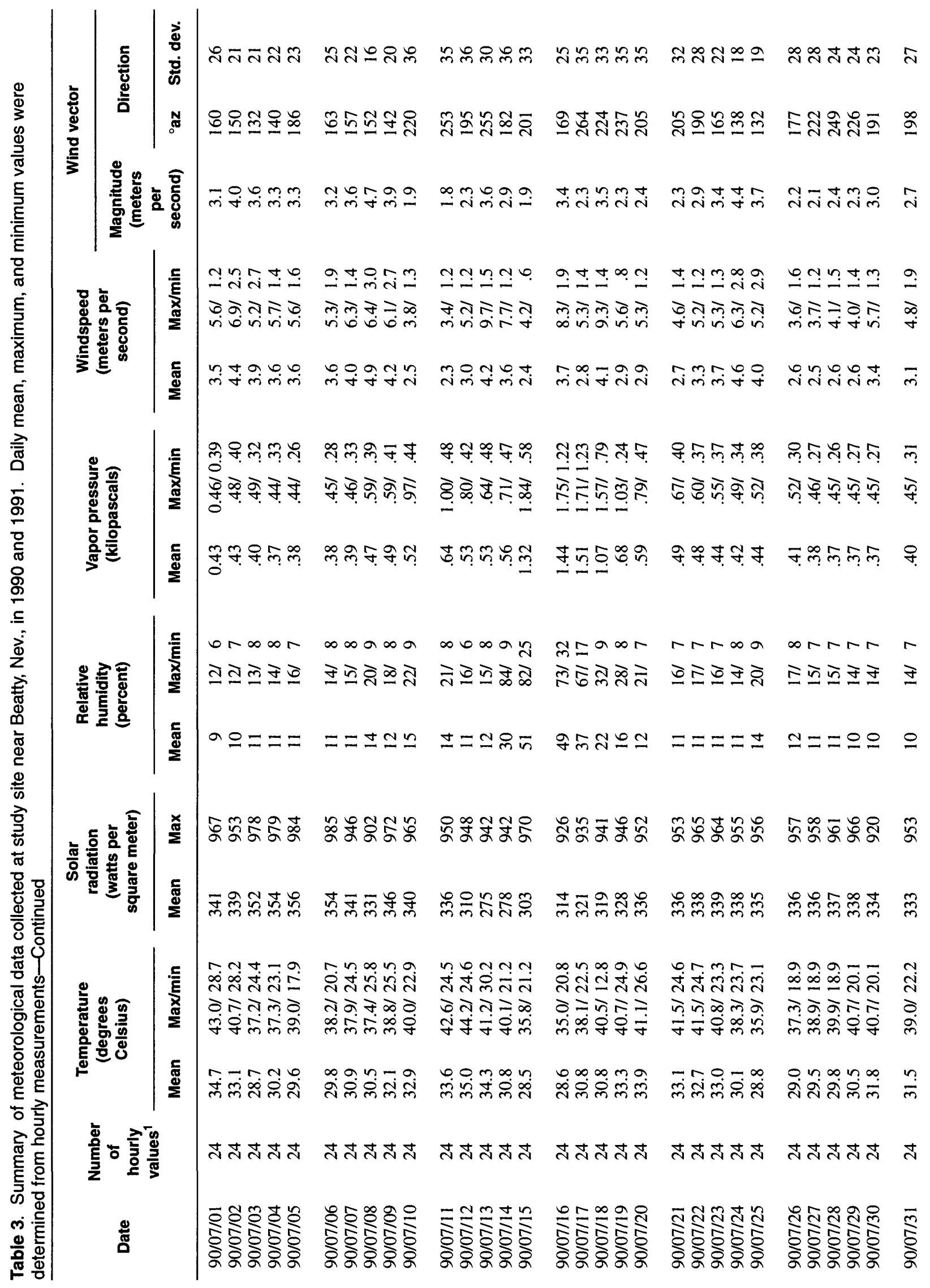




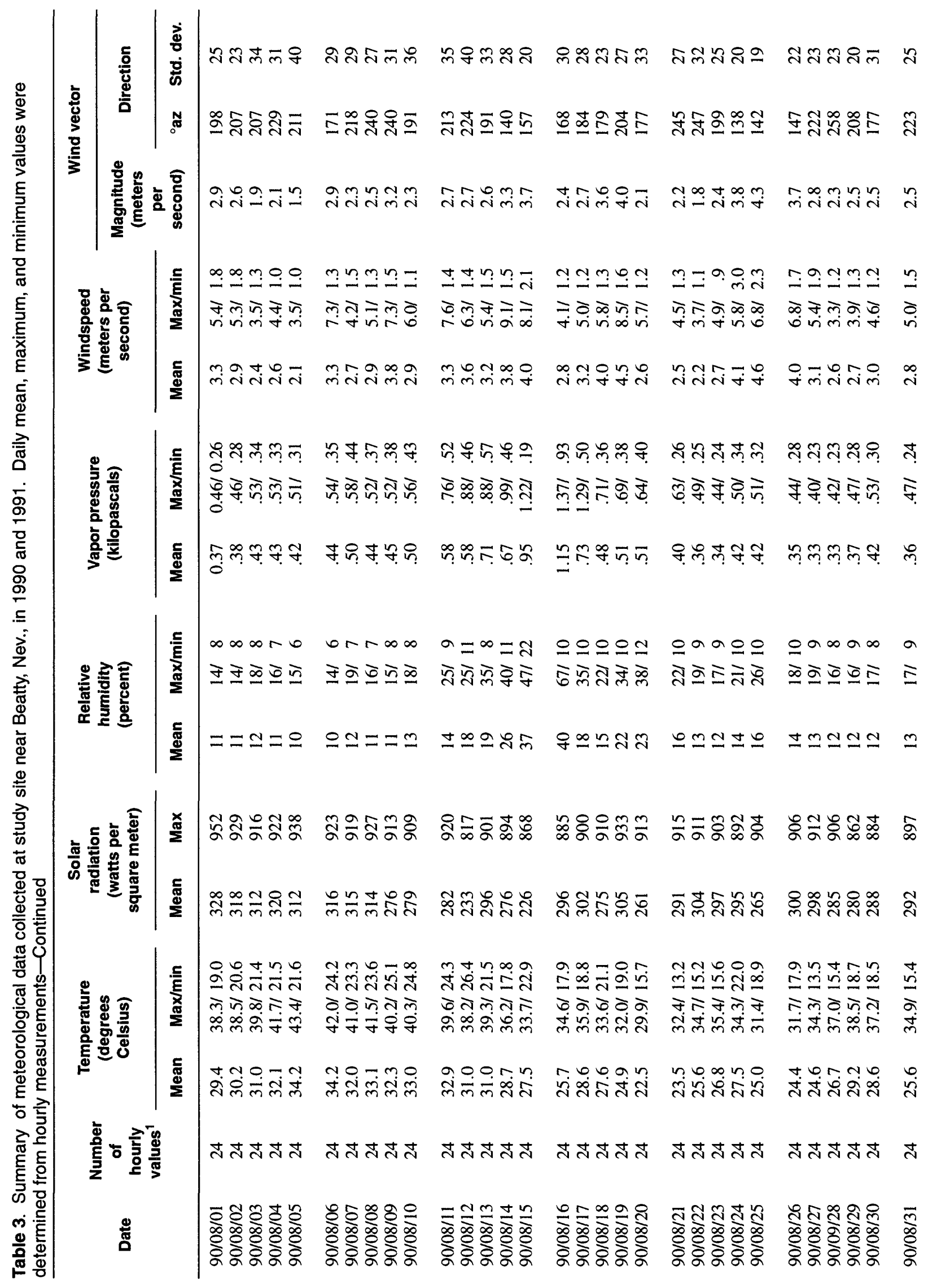




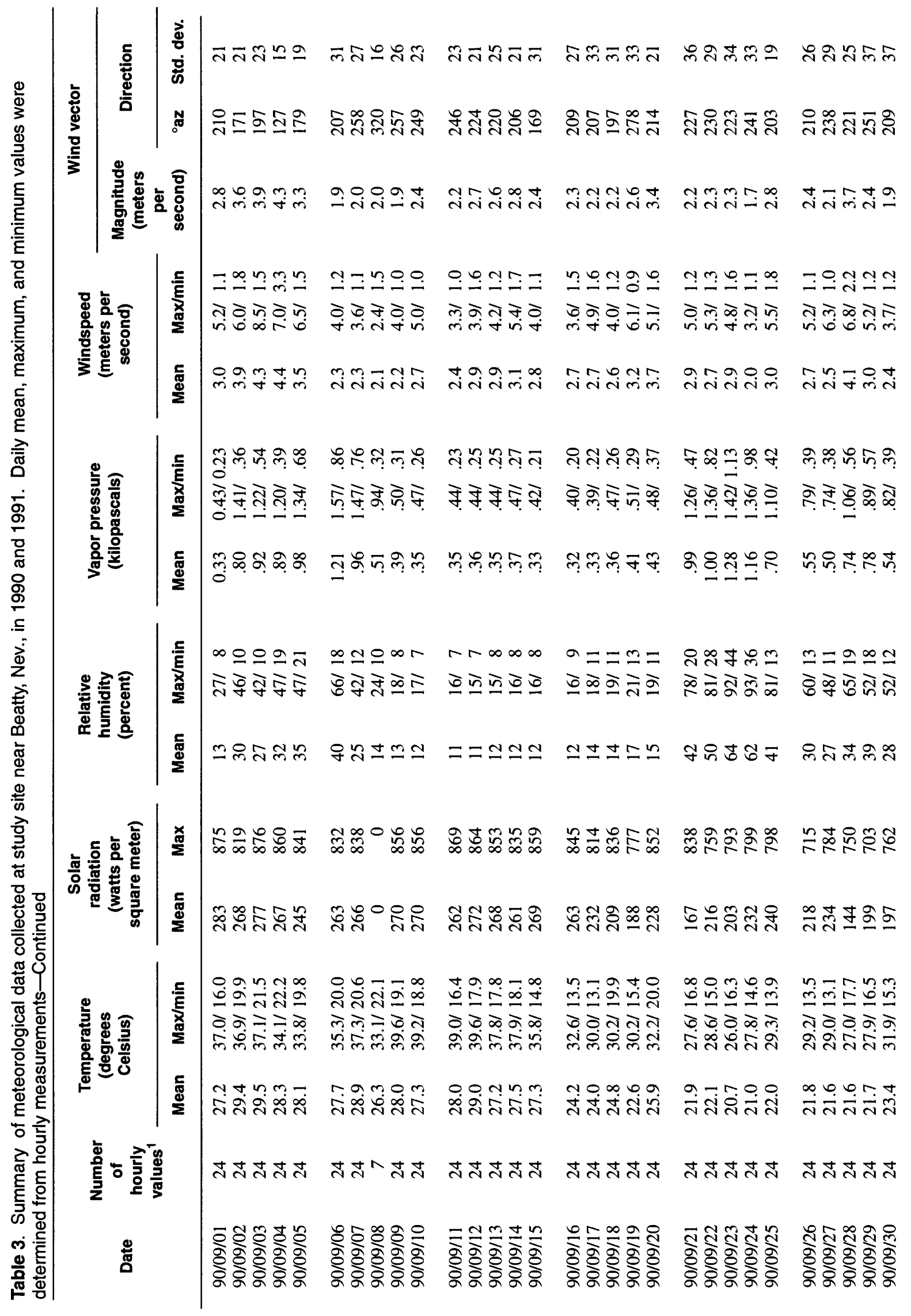




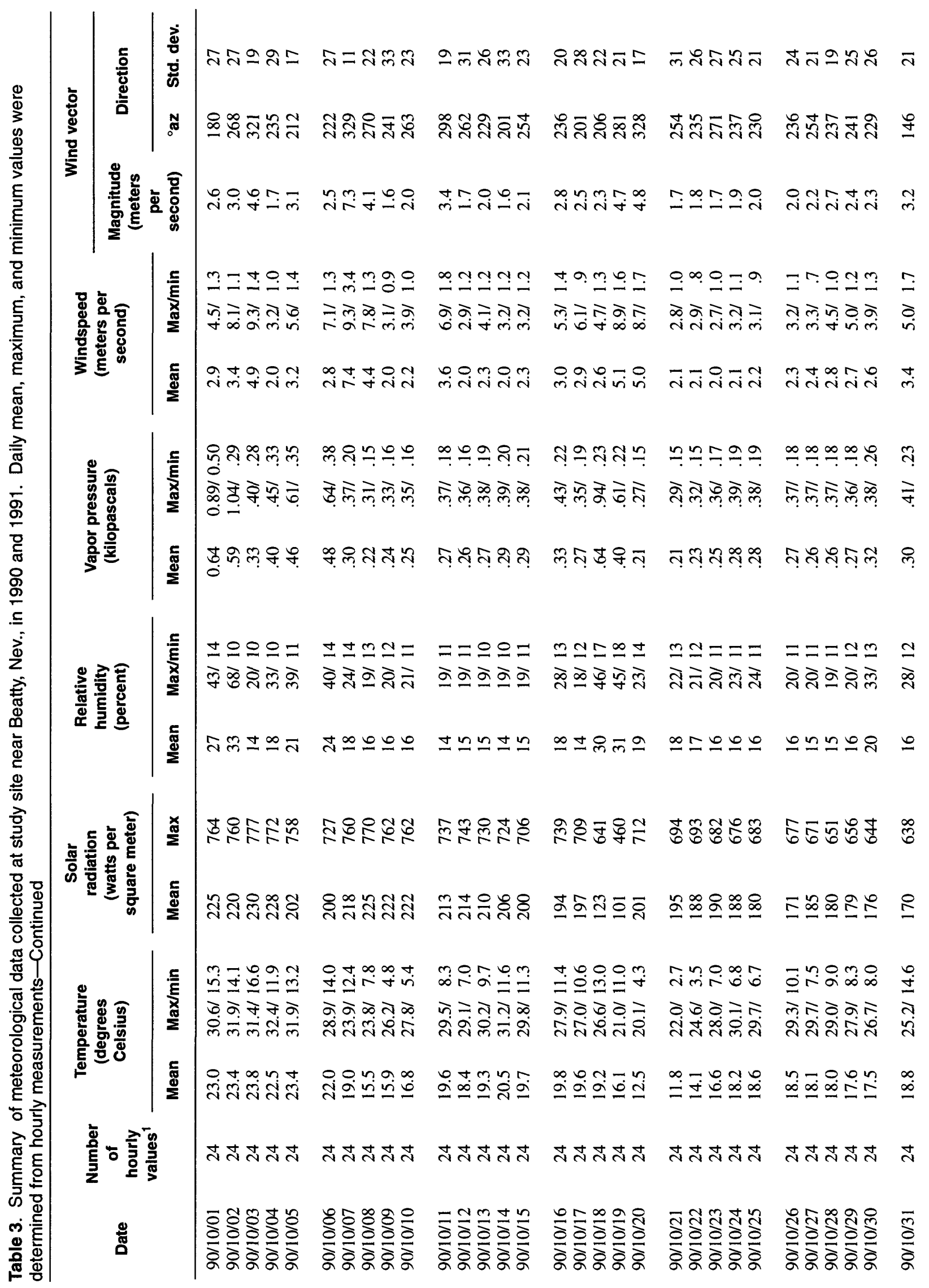




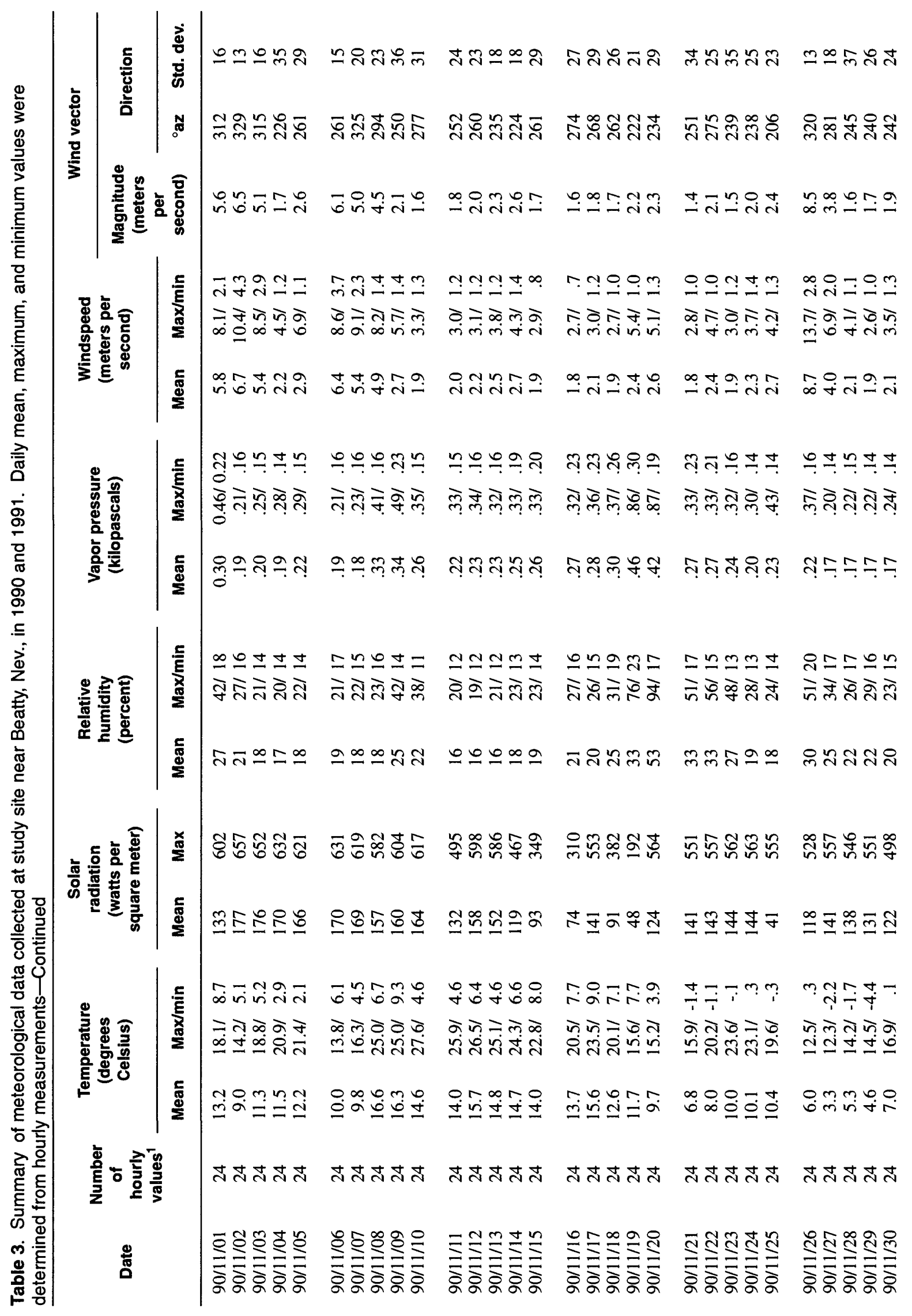




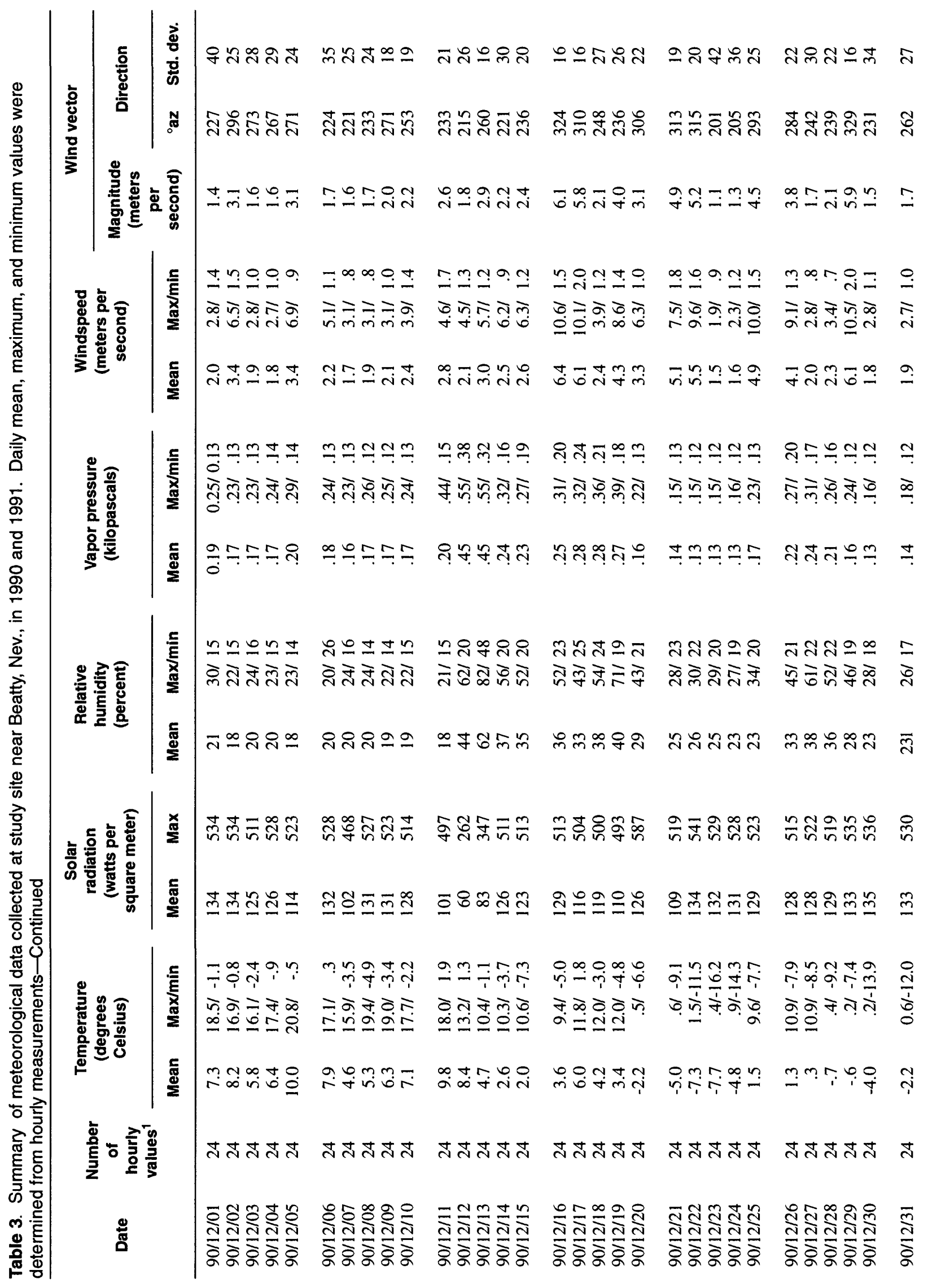


वे.

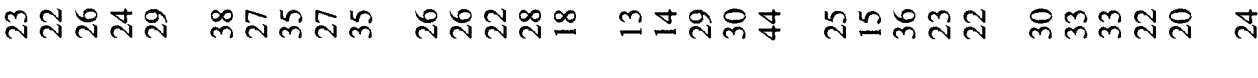

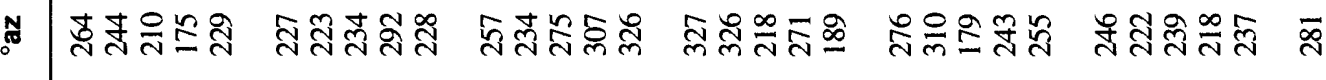
$\stackrel{\infty}{a} \underset{i}{0}=\stackrel{0}{=}$

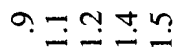

ropor

o.

$\infty \infty 9.0 m$

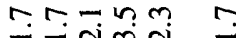

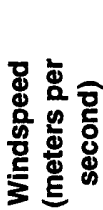

manr

0.9.

9.ำ 9

mm

$$
\text { กฺ }
$$

m ㄴ? $n-$

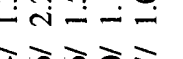

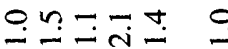

के च

कำ휴

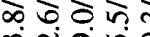

خकेळे

$\sim \sigma \dot{j} \dot{m}$

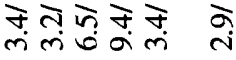

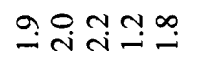

ำฺฺฺ

9979

每穴

ํํำกับ

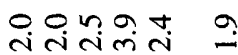

웅요요

ำำษ

$\forall a \infty \infty$

ํํำำ

$n ๒ \pm m$

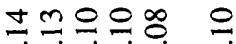

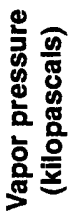

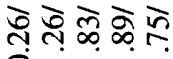

츟ํㅎํ

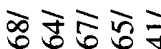

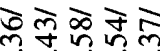

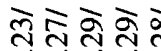

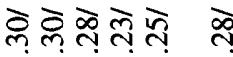

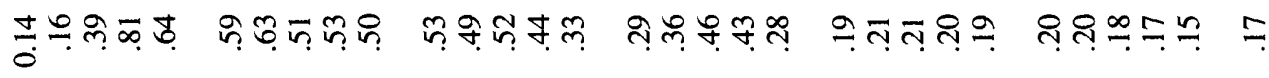

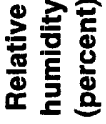

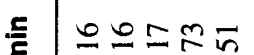

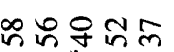

กั่กัณ

$\infty$ ป⿻ำ

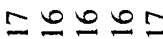

으는

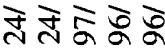

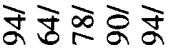

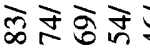

ल츰ㅎํ

১্ঠেন্ডু ন্ল

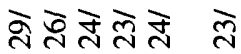

중유

ำกำ

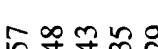

눙ㅇㅇㅇ

ูํㅇㅇำ

뀨유윤

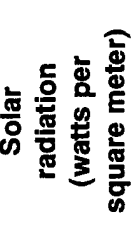

むすすすす

$=8 m$ m 8

$\pm \div \infty \bar{m}$

Ұ8

ธุฐฐ

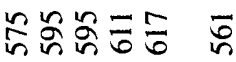

Nㅡㅁํํㄱ

ำํํำ

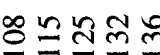

웡ำำ

乎ㅇำกำ

ทึํํํํำ

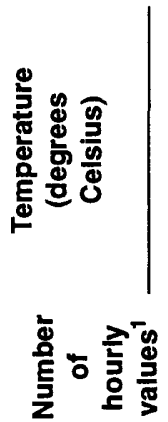

กั่สุดั

ตें

ำำกำ

ขึำกำ

$\frac{1}{1}$

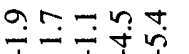

0 ํํㅇำ

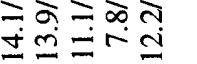

可方公

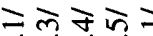

俞

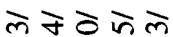

寸゚

斗

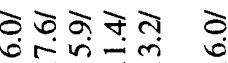

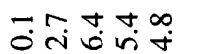

N $\ln \infty \sin$

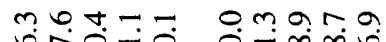

I.t. 70

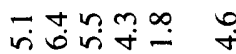

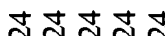

A

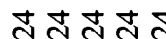

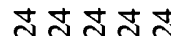

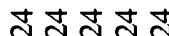

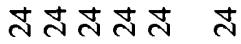

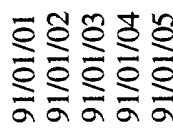

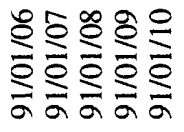

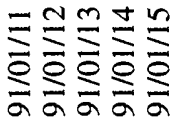

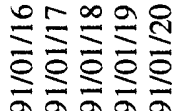

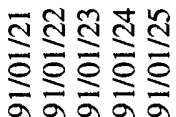

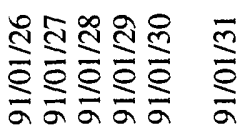




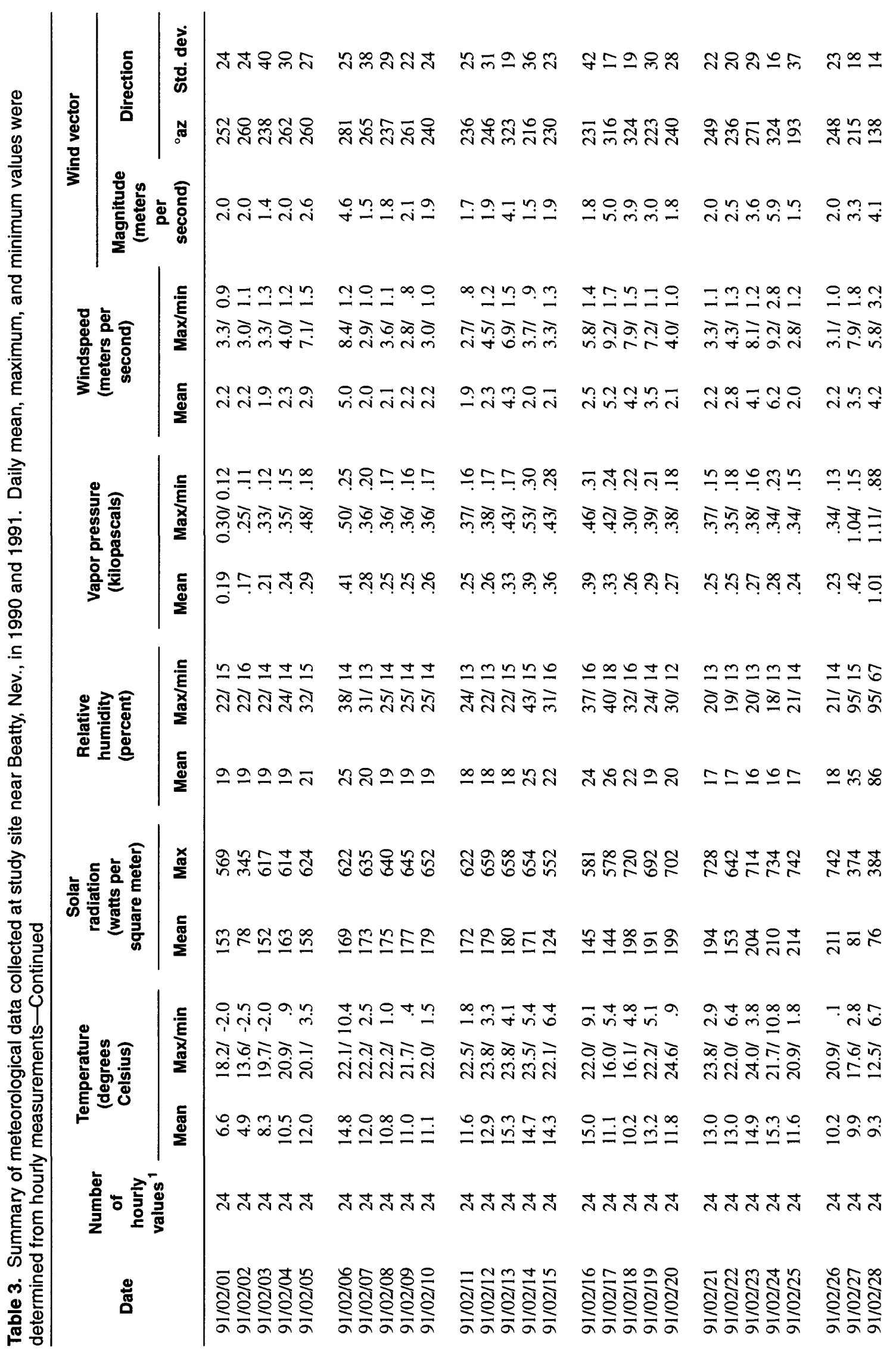




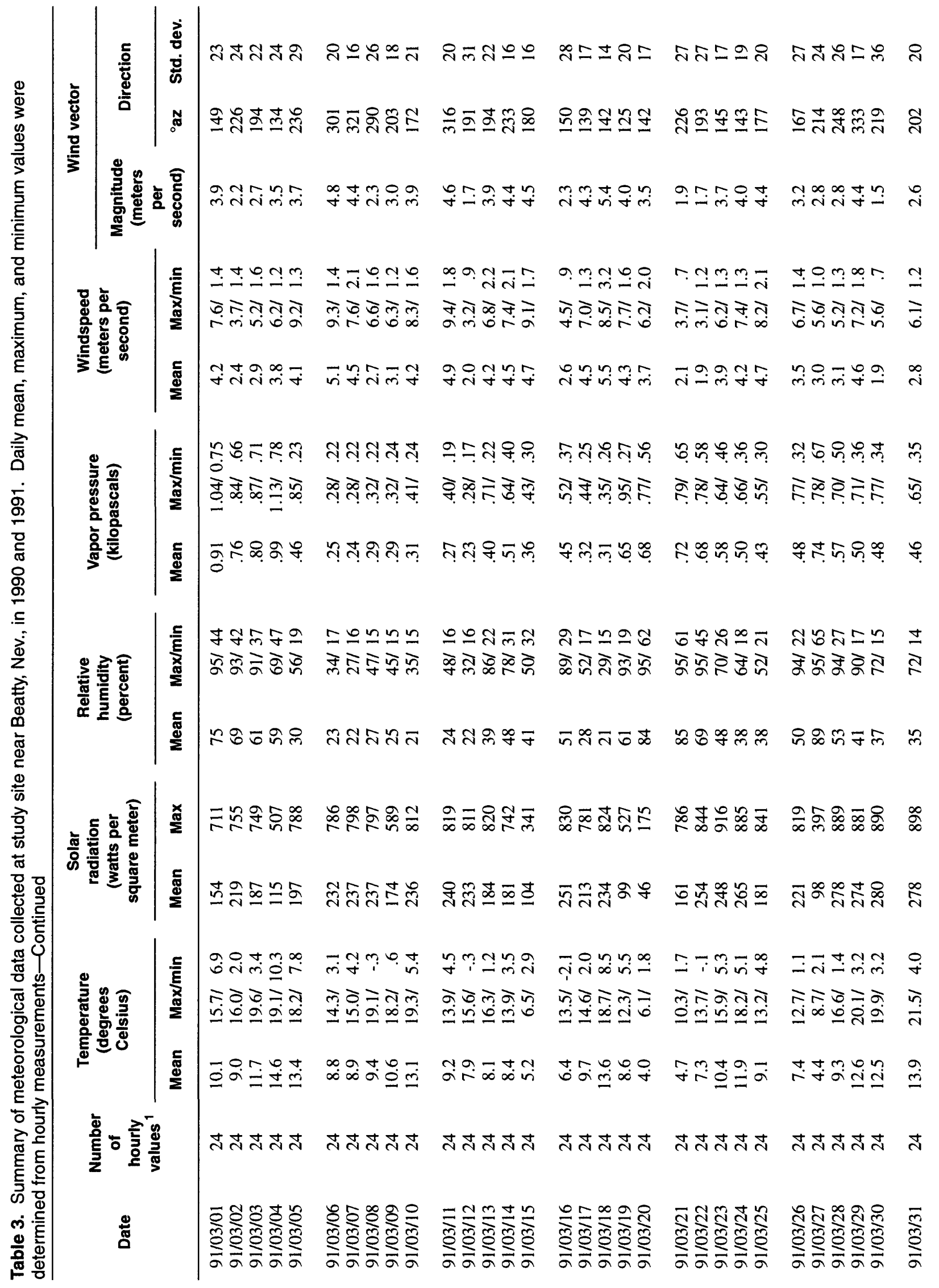




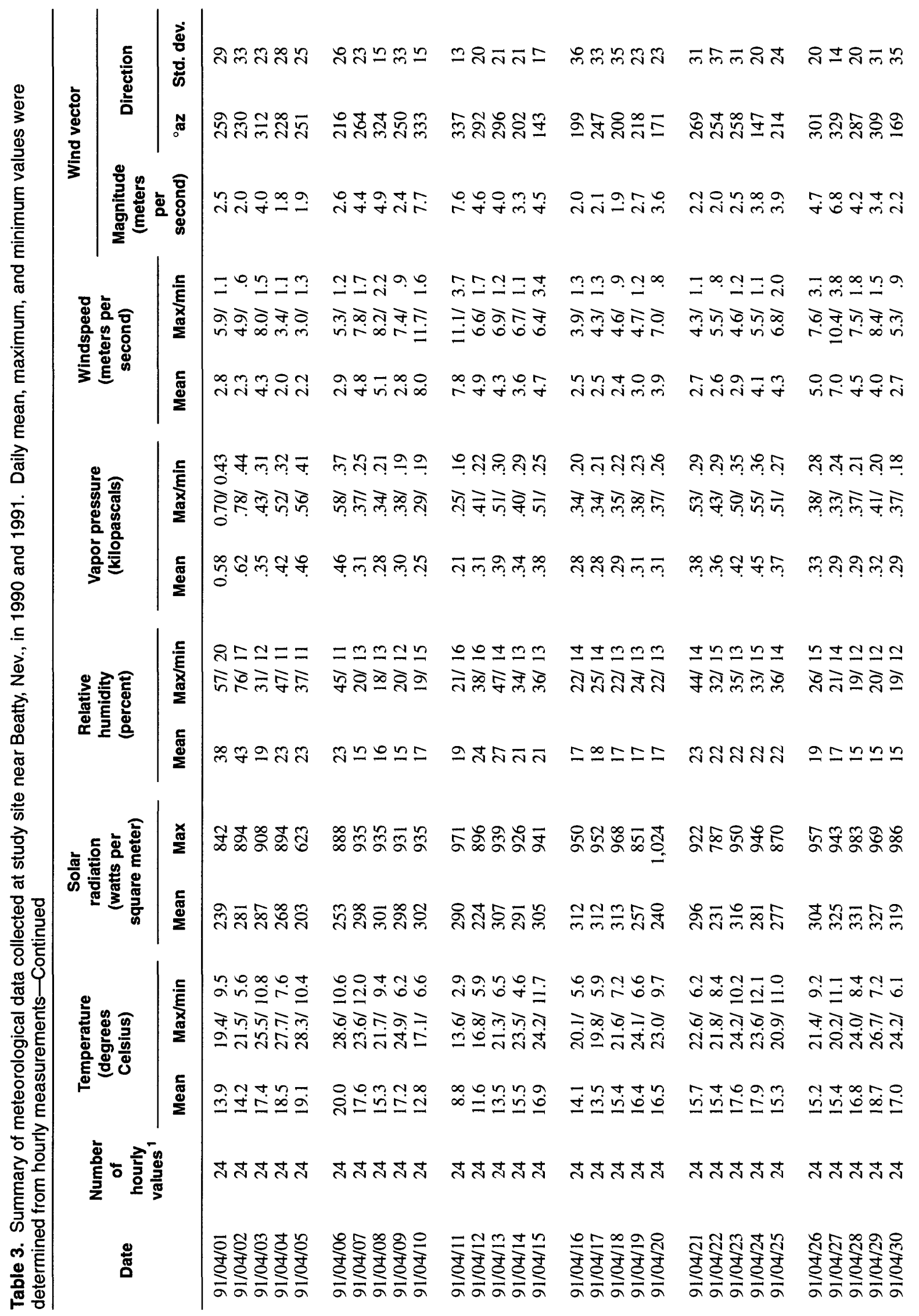




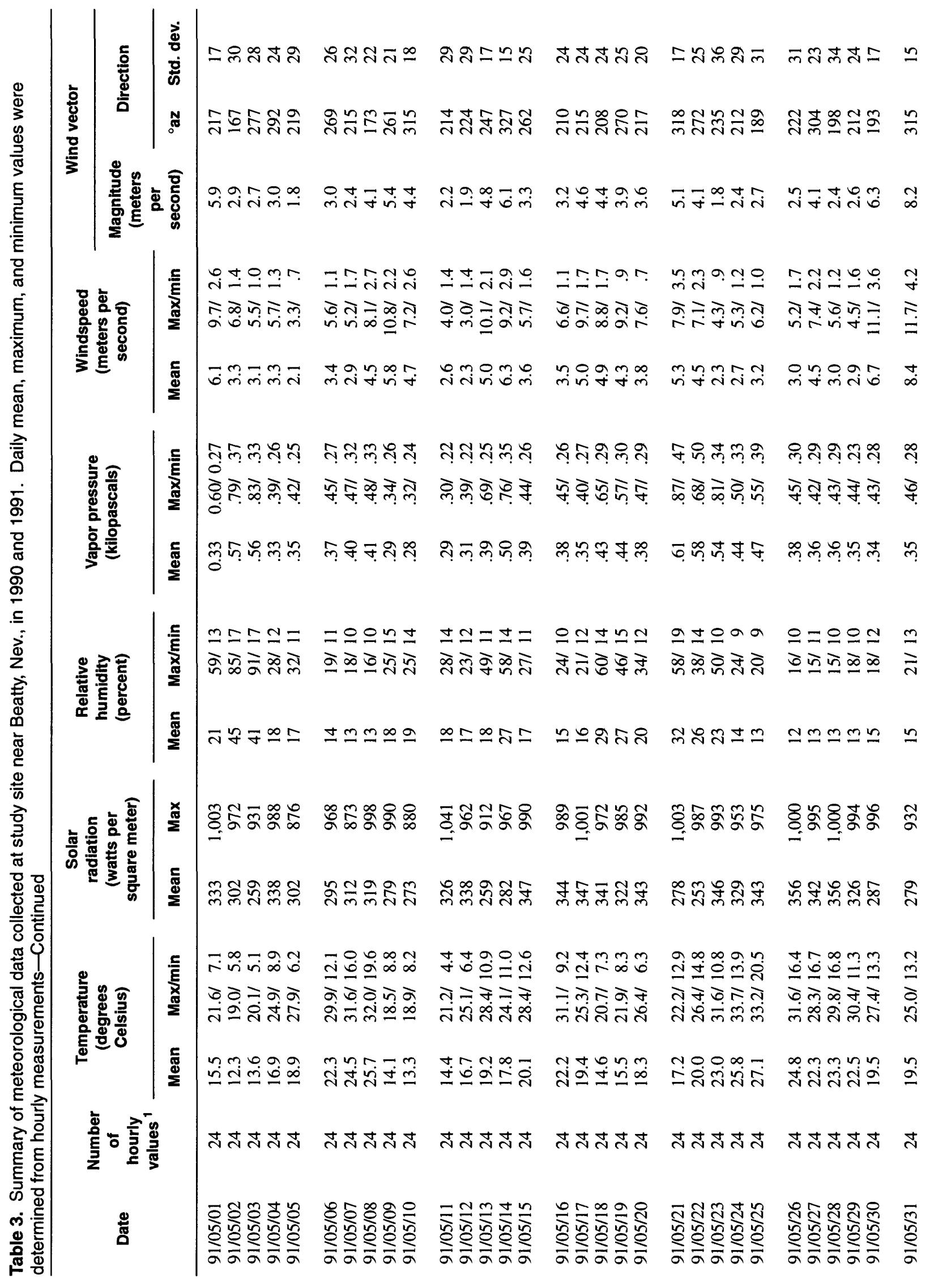




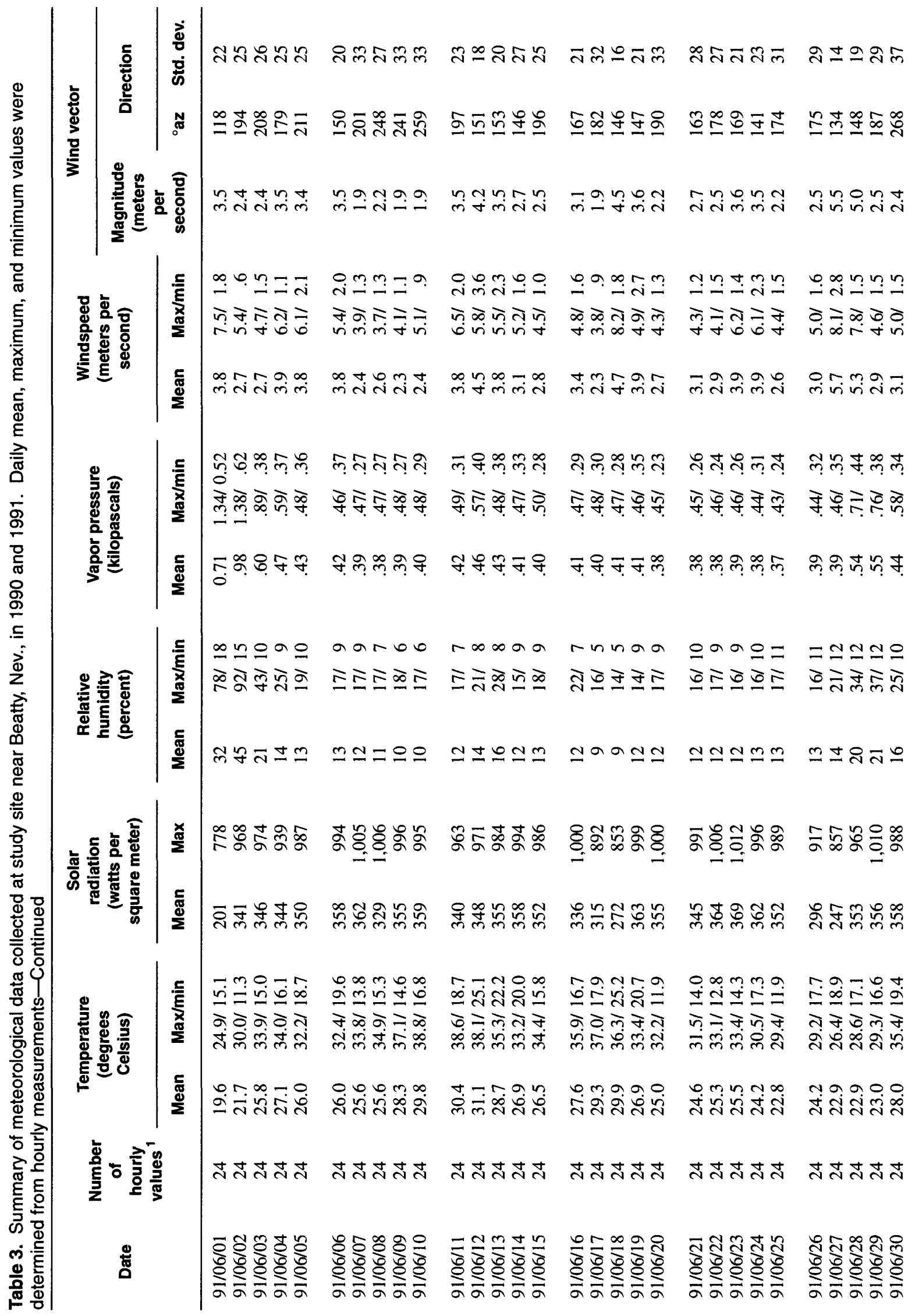




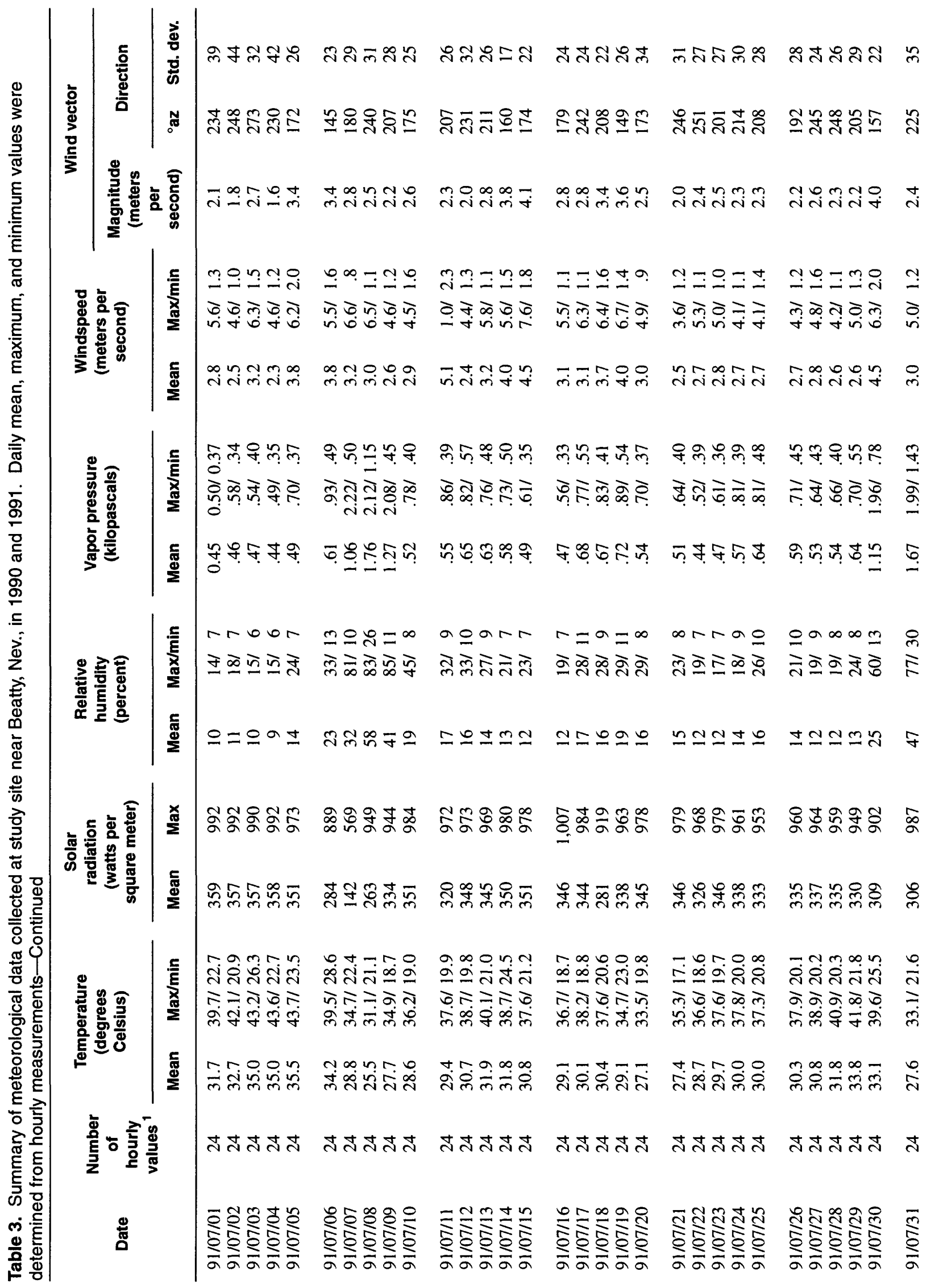




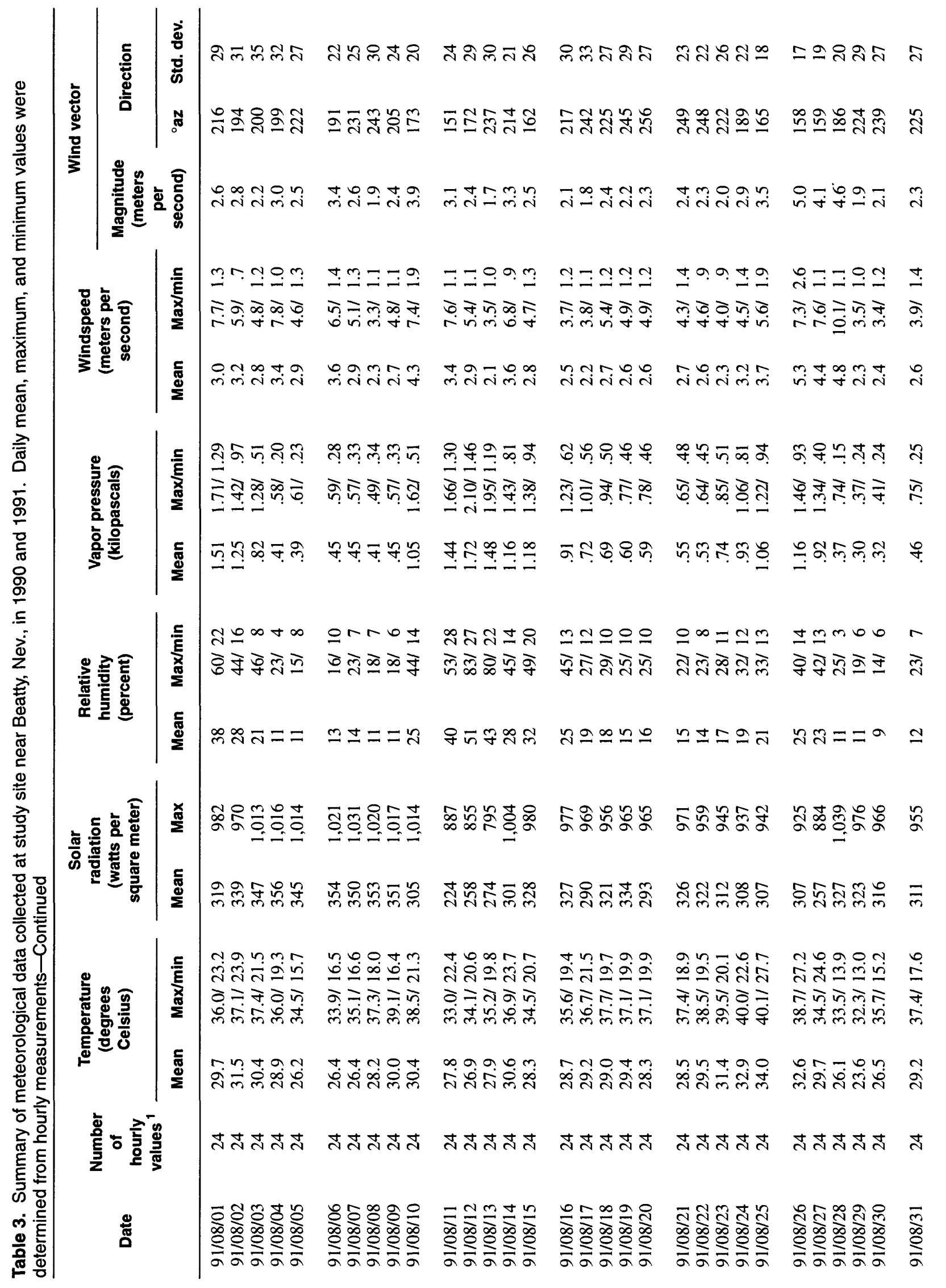




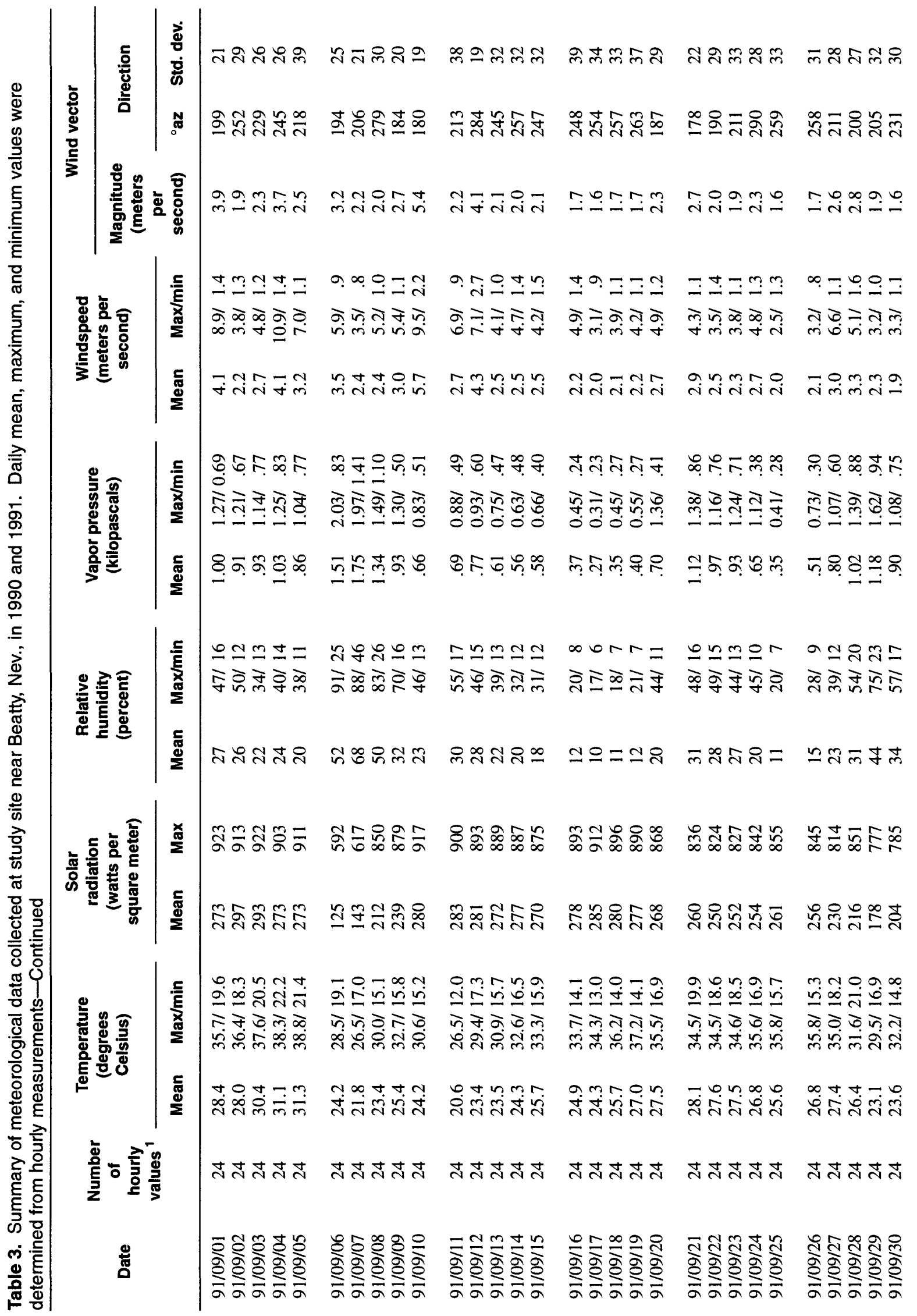




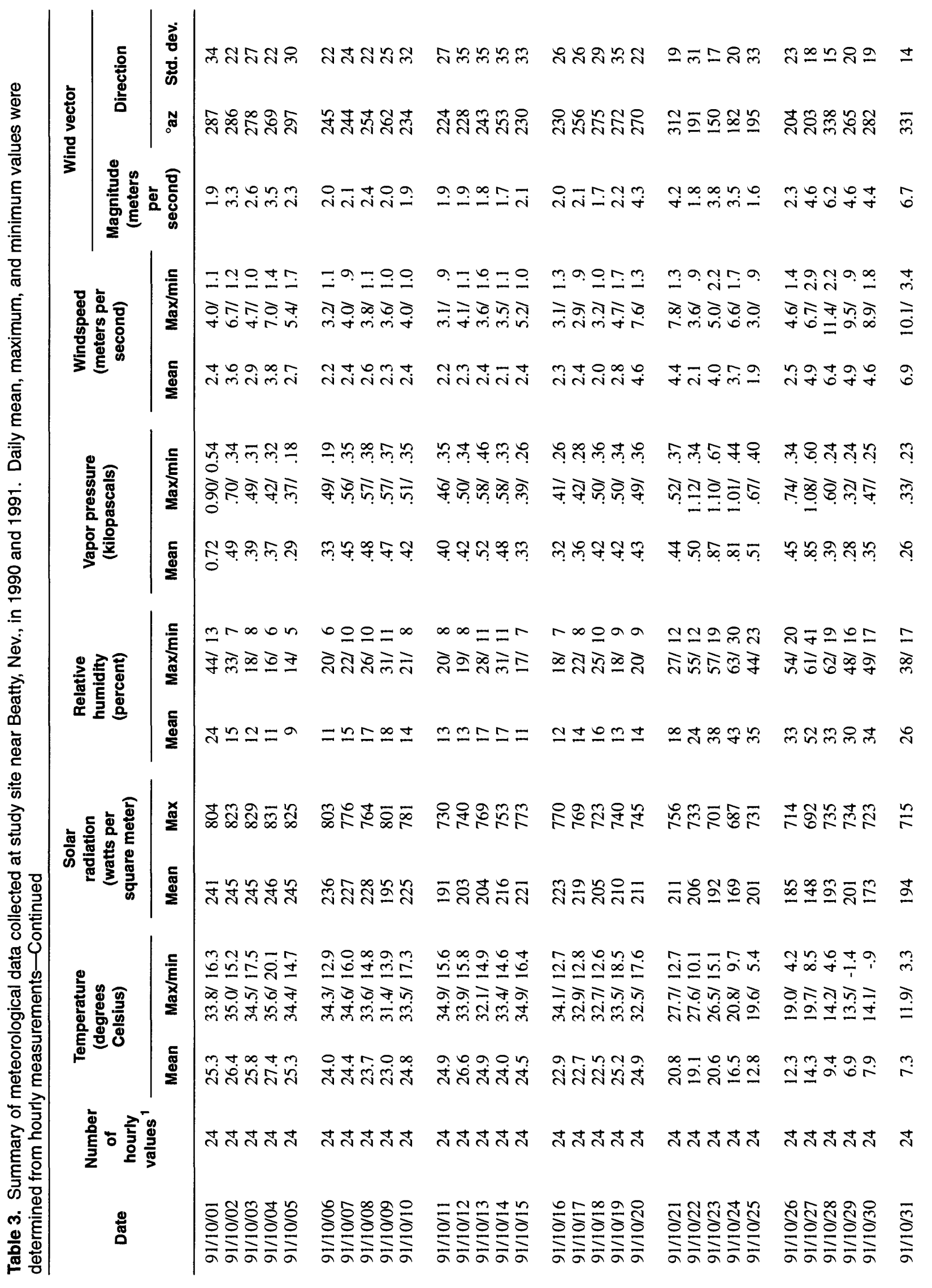




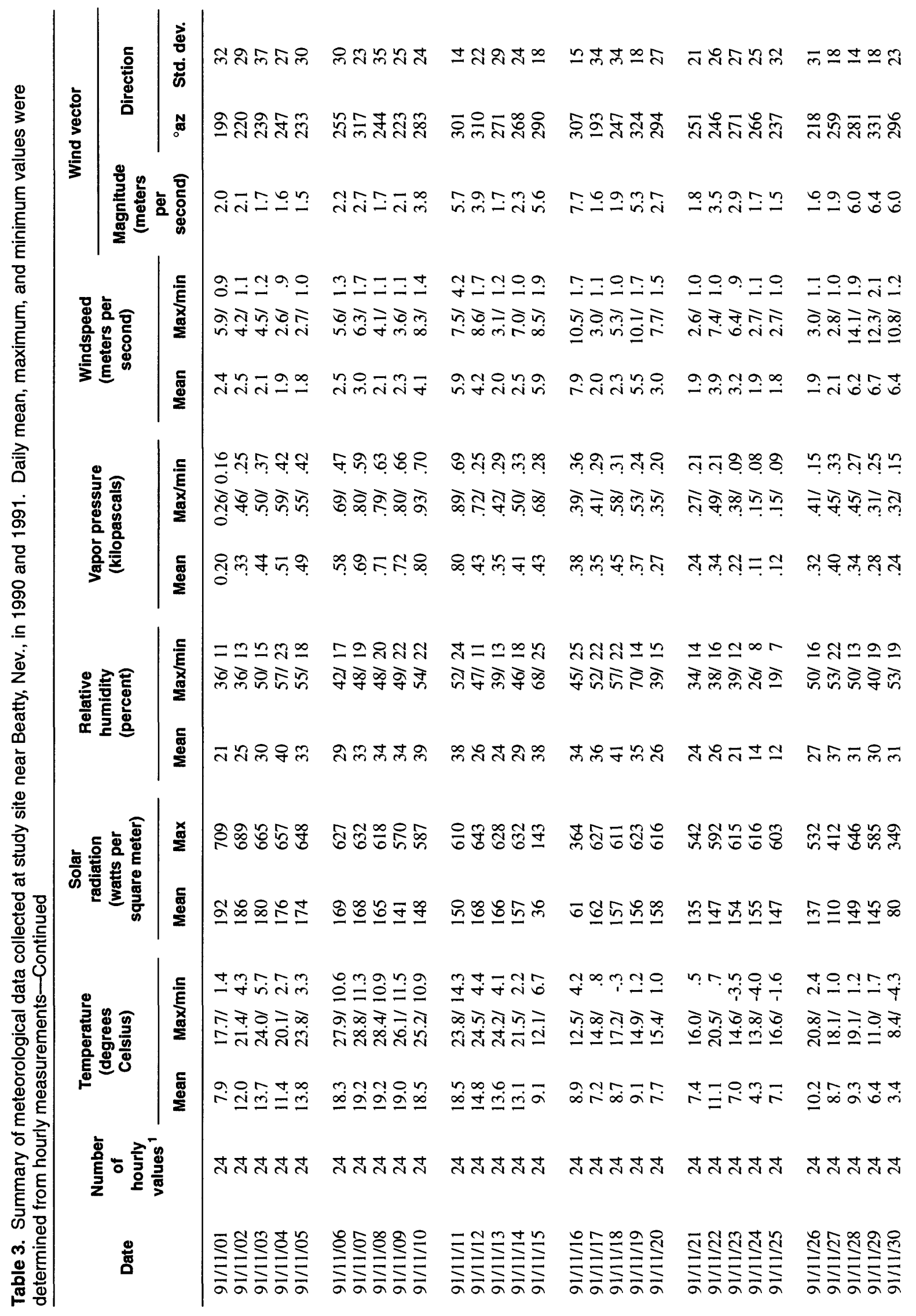




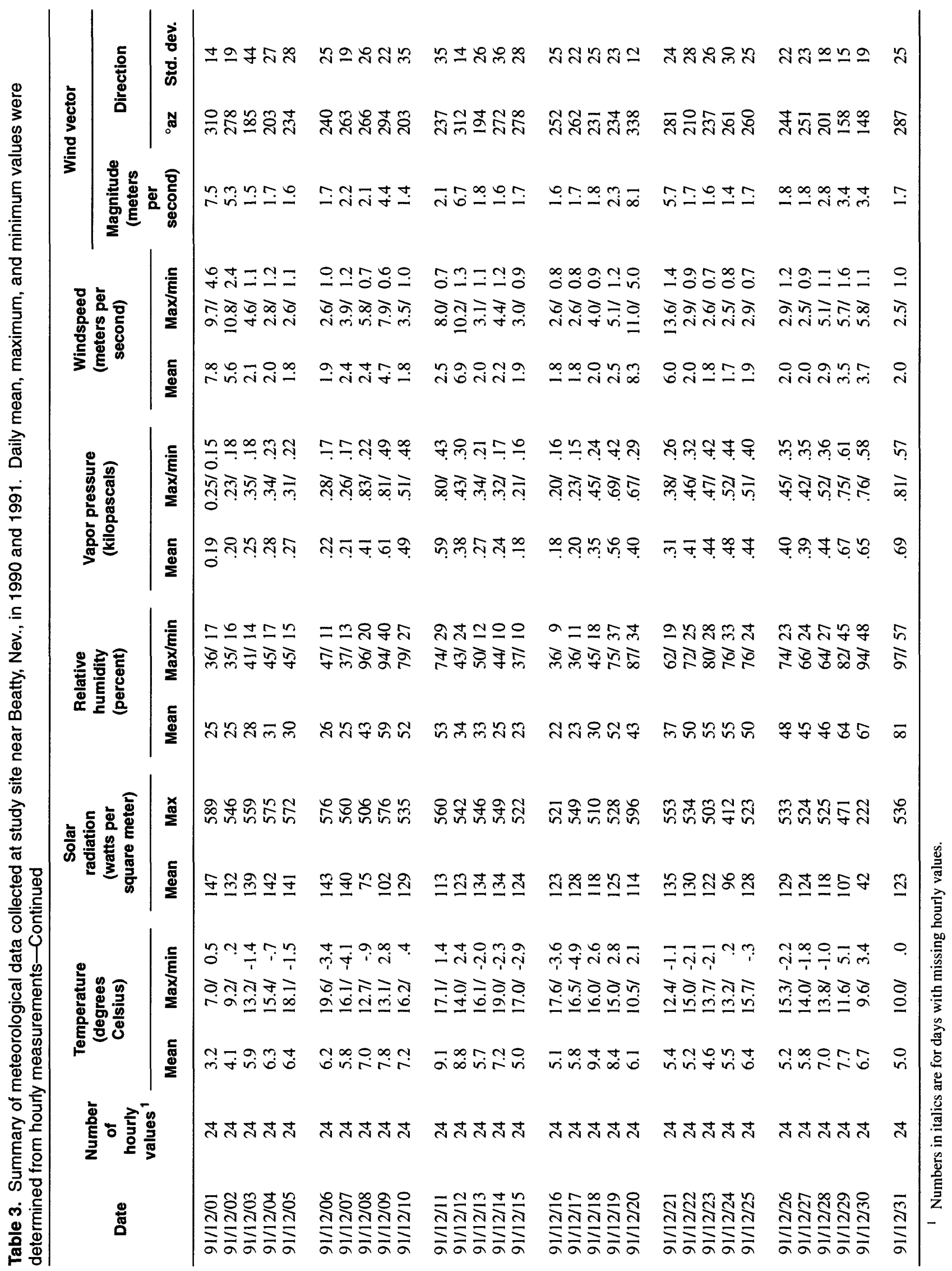


Table 4. Summary of barometric-pressure data collected at study site near Beatty, Nev., in 1990 and 1991. All daily mean, maximum, and minimum values were determined from individual measurements made every 30 seconds and averaged and recorded at 20-minute intervals in 1990, and at 10-minute intervals in 1991

\begin{tabular}{|c|c|c|c|c|c|c|c|}
\hline \multirow[b]{2}{*}{ Date } & \multicolumn{3}{|c|}{ Barometric pressure (kilopascais) } & \multirow[b]{2}{*}{ Date } & \multicolumn{3}{|c|}{ Barometric pressure (kilopascais) } \\
\hline & Mean & Maximum & Minimum & & Mean & Maximum & Minimum \\
\hline $90 / 06 / 02$ & 101.78 & 101.96 & 101.62 & $90 / 07 / 22$ & 101.29 & 101.54 & 101.04 \\
\hline $90 / 06 / 03$ & 101.63 & 101.92 & 101.33 & $90 / 07 / 23$ & 101.02 & 101.34 & 100.60 \\
\hline $90 / 06 / 04$ & 101.06 & 101.37 & 100.65 & $90 / 07 / 24$ & 100.77 & 101.01 & 100.46 \\
\hline $90 / 06 / 05$ & 100.86 & 101.08 & 100.59 & $90 / 07 / 25$ & 101.11 & 101.29 & 100.88 \\
\hline $90 / 06 / 06$ & 101.03 & 101.20 & 100.87 & $90 / 07 / 26$ & 101.49 & 101.69 & 101.30 \\
\hline $90 / 06 / 07$ & 101.29 & 101.50 & 101.11 & $90 / 07 / 27$ & 101.52 & 101.75 & 101.30 \\
\hline $90 / 06 / 08$ & 101.26 & 101.52 & 101.01 & $90 / 07 / 28$ & 101.44 & 101.66 & 101.25 \\
\hline $90 / 06 / 09$ & 101.18 & 101.43 & 100.99 & $90 / 07 / 29$ & 101.48 & 101.64 & 101.32 \\
\hline $90 / 06 / 10$ & 101.32 & 101.53 & 101.13 & $90 / 07 / 30$ & 101.50 & 101.72 & 101.28 \\
\hline $90 / 06 / 11$ & 101.30 & 101.62 & 100.96 & $90 / 07 / 31$ & 101.33 & 101.63 & 101.03 \\
\hline $90 / 06 / 12$ & 100.98 & 101.32 & 100.57 & $90 / 08 / 01$ & 101.25 & 101.47 & 101.03 \\
\hline $90 / 06 / 13$ & 100.52 & 100.76 & 100.12 & $90 / 08 / 02$ & 101.46 & 101.68 & 101.28 \\
\hline $90 / 06 / 14$ & 101.06 & 101.32 & 100.79 & $90 / 08 / 03$ & 101.65 & 101.84 & 101.49 \\
\hline $90 / 06 / 15$ & 101.04 & 101.16 & 100.93 & $90 / 08 / 04$ & 101.67 & 101.87 & 101.47 \\
\hline $90 / 06 / 16$ & 101.33 & 101.52 & 101.19 & $90 / 08 / 05$ & 101.64 & 101.87 & 101.41 \\
\hline $90 / 06 / 17$ & 101.24 & 101.44 & 101.07 & $90 / 08 / 06$ & 101.72 & 101.94 & 101.41 \\
\hline $90 / 06 / 18$ & 101.39 & 101.65 & 101.18 & $90 / 08 / 07$ & 101.71 & 101.95 & 101.43 \\
\hline $90 / 06 / 19$ & 101.63 & 101.90 & 101.39 & $90 / 08 / 08$ & 101.59 & 101.76 & 101.38 \\
\hline $90 / 06 / 20$ & 101.39 & 101.63 & 101.15 & $90 / 08 / 09$ & 101.66 & 101.91 & 101.42 \\
\hline $90 / 06 / 21$ & 101.20 & 101.41 & 101.01 & $90 / 08 / 10$ & 101.71 & 101.89 & 101.46 \\
\hline $90 / 06 / 22$ & 101.13 & 101.33 & 100.93 & $90 / 08 / 11$ & 101.68 & 101.91 & 101.41 \\
\hline $90 / 06 / 23$ & 101.26 & 101.42 & 101.10 & $90 / 08 / 12$ & 101.66 & 101.89 & 101.46 \\
\hline $90 / 06 / 24$ & 101.38 & 101.55 & 101.19 & $90 / 08 / 13$ & 101.37 & 101.62 & 101.07 \\
\hline $90 / 06 / 25$ & 101.48 & 101.70 & 101.29 & $90 / 08 / 14$ & 101.26 & 101.43 & 101.02 \\
\hline $90 / 06 / 26$ & 101.34 & 101.57 & 101.05 & $90 / 08 / 15$ & 101.27 & 101.52 & 100.92 \\
\hline $90 / 06 / 27$ & 101.14 & 101.39 & 100.84 & $90 / 08 / 16$ & 101.41 & 101.61 & 101.20 \\
\hline $90 / 06 / 28$ & 100.97 & 101.15 & 100.79 & $90 / 08 / 17$ & 101.27 & 101.53 & 100.99 \\
\hline $90 / 06 / 29$ & 101.19 & 101.35 & 100.98 & $90 / 08 / 18$ & 101.1 & 101.31 & 100.88 \\
\hline $90 / 06 / 30$ & 101.36 & 101.55 & 101.23 & $90 / 08 / 19$ & 101.06 & 101.23 & 100.78 \\
\hline $90 / 07 / 01$ & 101.25 & 101.54 & 100.93 & $90 / 08 / 20$ & 101.36 & 101.52 & 101.17 \\
\hline $90 / 07 / 02$ & 100.88 & 101.07 & 100.55 & $90 / 08 / 21$ & 101.68 & 101.86 & 101.50 \\
\hline $90 / 07 / 03$ & 101.06 & 101.25 & 100.84 & $90 / 08 / 22$ & 101.57 & 101.85 & 101.28 \\
\hline $90 / 07 / 04$ & 101.32 & 101.52 & 101.14 & $90 / 08 / 23$ & 101.14 & 101.38 & 100.86 \\
\hline $90 / 07 / 05$ & 101.25 & 101.46 & 101.00 & $90 / 08 / 24$ & 100.98 & 101.18 & 100.74 \\
\hline $90 / 07 / 06$ & 101.10 & 101.37 & 100.79 & $90 / 08 / 25$ & 101.22 & 101.43 & 101.02 \\
\hline $90 / 07 / 07$ & 101.03 & 101.23 & 100.83 & $90 / 08 / 26$ & 101.57 & 101.73 & 101.29 \\
\hline $90 / 07 / 08$ & 101.25 & 101.44 & 101.08 & $90 / 08 / 27$ & 101.86 & 102.06 & 101.70 \\
\hline $90 / 07 / 09$ & 101.59 & 101.76 & 101.42 & $90 / 08 / 28$ & 101.81 & 102.02 & 101.58 \\
\hline $90 / 07 / 10$ & 101.72 & 101.94 & 101.48 & $90 / 08 / 29$ & 101.53 & 101.79 & 101.21 \\
\hline $90 / 07 / 11$ & 101.61 & 101.85 & 101.35 & $90 / 08 / 30$ & 101.26 & 101.48 & 100.97 \\
\hline $90 / 07 / 12$ & 101.67 & 102.06 & 101.43 & $90 / 08 / 31$ & 101.35 & 101.53 & 101.19 \\
\hline $90 / 07 / 13$ & 101.75 & 102.00 & 101.45 & $90 / 09 / 01$ & 101.43 & 101.63 & 101.25 \\
\hline $90 / 07 / 14$ & 101.40 & 101.64 & 100.95 & $90 / 09 / 02$ & 101.49 & 101.71 & 101.24 \\
\hline $90 / 07 / 15$ & 101.25 & 101.38 & 101.07 & $90 / 09 / 03$ & 101.39 & 101.57 & 101.12 \\
\hline $90 / 07 / 16$ & 101.58 & 101.72 & 101.38 & $90 / 09 / 04$ & 101.71 & 101.90 & 101.53 \\
\hline $90 / 07 / 17$ & 101.59 & 101.77 & 101.36 & $90 / 09 / 05$ & 101.81 & 101.99 & 101.62 \\
\hline $90 / 07 / 18$ & 101.43 & 101.66 & 101.17 & $90 / 09 / 06$ & 101.83 & 102.06 & 101.58 \\
\hline $90 / 07 / 19$ & 101.25 & 101.45 & 101.00 & $90 / 09 / 07$ & 101.66 & 101.86 & 101.43 \\
\hline $90 / 07 / 20$ & 101.25 & 101.46 & 101.06 & $90 / 09 / 08$ & 101.46 & 101.58 & 101.36 \\
\hline $90 / 07 / 21$ & 101.34 & 101.57 & 101.13 & $90 / 09 / 09$ & 101.52 & 101.68 & 101.37 \\
\hline
\end{tabular}


Table 4. Summary of barometric-pressure data collected at study site near Beatty, Nev., in 1990 and 1991 -Continued

\begin{tabular}{|c|c|c|c|c|c|c|c|}
\hline \multirow[b]{2}{*}{ Date } & \multicolumn{3}{|c|}{ Barometric pressure (kilopascals) } & \multirow[b]{2}{*}{ Date } & \multicolumn{3}{|c|}{ Barometric pressure (kilopascals) } \\
\hline & Mean & Maximum & Minimum & & Mean & Maximum & Minimum \\
\hline $90 / 09 / 10$ & 101.54 & 101.74 & 101.38 & $90 / 10 / 30$ & 101.70 & 101.98 & 101.49 \\
\hline $90 / 09 / 11$ & 101.48 & 101.70 & 101.30 & $90 / 10 / 31$ & 101.23 & 101.47 & 100.98 \\
\hline $90 / 09 / 12$ & 101.36 & 101.59 & 101.12 & $90 / 11 / 01$ & 101.21 & 101.50 & 101.04 \\
\hline $90 / 09 / 13$ & 101.31 & 101.49 & 101.15 & $90 / 11 / 02$ & 101.79 & 102.15 & 101.54 \\
\hline $90 / 09 / 14$ & 101.36 & 101.58 & 101.16 & $90 / 11 / 03$ & 102.34 & 102.54 & 102.17 \\
\hline $90 / 09 / 15$ & 101.23 & 101.49 & 100.92 & $90 / 11 / 04$ & 102.29 & 102.60 & 101.88 \\
\hline $90 / 09 / 16$ & 101.00 & 101.26 & 100.77 & $90 / 11 / 05$ & 101.29 & 101.82 & 100.86 \\
\hline $90 / 09 / 17$ & 101.08 & 101.22 & 100.90 & $90 / 11 / 06$ & 101.78 & 102.09 & 101.35 \\
\hline $90 / 09 / 18$ & 101.27 & 101.45 & 101.15 & $90 / 11 / 07$ & 102.23 & 102.50 & 102.03 \\
\hline $90 / 09 / 19$ & 101.29 & 101.47 & 101.11 & $90 / 11 / 08$ & 102.29 & 102.45 & 102.08 \\
\hline $90 / 09 / 20$ & 101.25 & 101.47 & 101.09 & $90 / 11 / 09$ & 102.48 & 102.74 & 102.25 \\
\hline $90 / 09 / 21$ & 101.71 & 101.90 & 101.49 & $90 / 11 / 10$ & 102.38 & 102.54 & 102.19 \\
\hline $90 / 09 / 22$ & 101.89 & 102.05 & 101.74 & $90 / 11 / 11$ & 102.38 & 102.52 & 102.24 \\
\hline $90 / 09 / 23$ & 101.87 & 102.13 & 101.65 & $90 / 11 / 12$ & 102.34 & 102.58 & 102.12 \\
\hline $90 / 09 / 24$ & 101.76 & 101.96 & 101.60 & $90 / 11 / 13$ & 101.80 & 102.09 & 101.56 \\
\hline $90 / 09 / 25$ & 101.66 & 101.86 & 101.50 & $90 / 11 / 14$ & 101.53 & 101.69 & 101.38 \\
\hline $90 / 09 / 26$ & 101.53 & 101.76 & 101.35 & $90 / 11 / 15$ & 102.08 & 102.38 & 101.71 \\
\hline $90 / 09 / 27$ & 101.28 & 101.48 & 101.08 & $90 / 11 / 16$ & 102.22 & 102.42 & 102.02 \\
\hline $90 / 09 / 28$ & 101.42 & 101.55 & 101.23 & $90 / 11 / 17$ & 101.80 & 102.04 & 101.55 \\
\hline $90 / 09 / 29$ & 101.63 & 101.77 & 101.50 & $90 / 11 / 18$ & 101.39 & 101.58 & 101.22 \\
\hline $90 / 09 / 30$ & 101.75 & 101.92 & 101.57 & $90 / 11 / 19$ & 100.88 & 101.19 & 100.60 \\
\hline $90 / 10 / 01$ & 101.55 & 101.86 & 101.26 & $90 / 11 / 20$ & 101.01 & 101.67 & 100.49 \\
\hline $90 / 10 / 02$ & 101.12 & 101.33 & 100.79 & $90 / 11 / 21$ & 102.04 & 102.47 & 101.71 \\
\hline $90 / 10 / 03$ & 101.79 & 102.13 & 101.33 & $90 / 11 / 22$ & 102.58 & 102.81 & 102.41 \\
\hline $90 / 10 / 04$ & 102.04 & 102.32 & 101.78 & $90 / 11 / 23$ & 102.31 & 102.57 & 102.05 \\
\hline $90 / 10 / 05$ & 101.50 & 101.86 & 101.17 & $90 / 11 / 24$ & 101.91 & 102.10 & 101.68 \\
\hline $90 / 10 / 06$ & 101.15 & 101.36 & 100.98 & $90 / 11 / 25$ & 101.04 & 101.80 & 99.83 \\
\hline $90 / 10 / 07$ & 101.54 & 102.21 & 101.06 & $90 / 11 / 26$ & 100.89 & 101.93 & 99.78 \\
\hline $90 / 10 / 08$ & 102.50 & 102.67 & 102.26 & $90 / 11 / 27$ & 102.13 & 102.49 & 101.90 \\
\hline $90 / 10 / 09$ & 102.49 & 102.84 & 102.14 & $90 / 11 / 28$ & 102.91 & 103.12 & 102.52 \\
\hline $90 / 10 / 10$ & 101.69 & 102.11 & 101.36 & $90 / 11 / 29$ & 102.71 & 103.07 & 102.32 \\
\hline $90 / 10 / 11$ & 101.59 & 101.81 & 101.42 & $90 / 11 / 30$ & 102.08 & 102.27 & 101.89 \\
\hline $90 / 10 / 12$ & 101.74 & 102.02 & 101.50 & $90 / 12 / 01$ & 102.06 & 102.25 & 101.86 \\
\hline $90 / 10 / 13$ & 101.36 & 101.51 & 101.16 & $90 / 12 / 02$ & 102.53 & 102.74 & 102.24 \\
\hline $90 / 10 / 14$ & 101.40 & 101.59 & 101.25 & $90 / 12 / 03$ & 102.83 & 103.06 & 102.68 \\
\hline $90 / 10 / 15$ & 101.38 & 101.62 & 101.19 & $90 / 12 / 04$ & 102.62 & 102.83 & 102.42 \\
\hline $90 / 10 / 16$ & 101.24 & 101.50 & 101.05 & $90 / 12 / 05$ & 102.38 & 102.63 & 102.19 \\
\hline $90 / 10 / 17$ & 101.83 & 102.04 & 101.55 & $90 / 12 / 06$ & 102.77 & 103.01 & 102.64 \\
\hline $90 / 10 / 18$ & 101.46 & 101.82 & 100.95 & $90 / 12 / 07$ & 102.60 & 102.79 & 102.41 \\
\hline $90 / 10 / 19$ & 101.22 & 101.79 & 100.92 & $90 / 12 / 08$ & 102.46 & 102.65 & 102.28 \\
\hline $90 / 10 / 20$ & 102.06 & 102.30 & 101.81 & $90 / 12 / 09$ & 102.33 & 102.53 & 102.14 \\
\hline $90 / 10 / 21$ & 102.25 & 102.50 & 102.00 & $90 / 12 / 10$ & 101.98 & 102.20 & 101.74 \\
\hline $90 / 10 / 22$ & 101.79 & 101.97 & 101.57 & $90 / 12 / 11$ & 101.46 & 101.70 & 101.25 \\
\hline $90 / 10 / 23$ & 101.89 & 102.11 & 101.75 & $90 / 12 / 12$ & 101.52 & 101.65 & 101.36 \\
\hline $90 / 10 / 24$ & 102.16 & 102.35 & 102.03 & $90 / 12 / 13$ & 101.47 & 101.69 & 101.21 \\
\hline $90 / 10 / 25$ & 102.06 & 102.26 & 101.89 & $90 / 12 / 14$ & 101.90 & 102.17 & 101.72 \\
\hline $90 / 10 / 26$ & 101.93 & 102.05 & 101.78 & $90 / 12 / 15$ & 101.28 & 101.70 & 100.90 \\
\hline $90 / 10 / 27$ & 102.01 & 102.21 & 101.85 & $90 / 12 / 16$ & 101.37 & 101.79 & 101.18 \\
\hline $90 / 10 / 28$ & 101.82 & 102.02 & 101.61 & $90 / 12 / 17$ & 102.15 & 102.33 & 101.80 \\
\hline $90 / 10 / 29$ & 101.63 & 101.78 & 101.48 & $90 / 12 / 18$ & 101.39 & 102.14 & 100.44 \\
\hline
\end{tabular}


Tabie 4. Summary of barometric-pressure data collected at study site near Beatty, Nev., in 1990 and 1991 -Continued

\begin{tabular}{|c|c|c|c|c|c|c|c|}
\hline \multirow[b]{2}{*}{ Date } & \multicolumn{3}{|c|}{ Barometric pressure (kilopascals) } & \multirow[b]{2}{*}{ Date } & \multicolumn{3}{|c|}{ Barometric pressure (kilopascals) } \\
\hline & Mean & Maximum & Minimum & & Mean & Maximum & Minlmum \\
\hline $\begin{array}{l}90 / 12 / 19 \\
90 / 12 / 20 \\
90 / 12 / 21 \\
90 / 12 / 22 \\
90 / 12 / 23\end{array}$ & $\begin{array}{r}99.82 \\
100.48 \\
101.11 \\
101.94 \\
102.89\end{array}$ & $\begin{array}{l}100.30 \\
100.72 \\
101.54 \\
102.55 \\
103.12\end{array}$ & $\begin{array}{r}99.47 \\
100.01 \\
100.72 \\
101.52 \\
102.57\end{array}$ & $\begin{array}{l}91 / 02 / 07 \\
91 / 02 / 08 \\
91 / 02 / 09 \\
91 / 02 / 10 \\
91 / 02 / 11\end{array}$ & $\begin{array}{l}102.22 \\
102.15 \\
102.06 \\
101.82 \\
101.82\end{array}$ & $\begin{array}{l}102.40 \\
102.33 \\
102.33 \\
102.00 \\
102.05\end{array}$ & $\begin{array}{l}102.00 \\
101.98 \\
101.81 \\
101.64 \\
101.67\end{array}$ \\
\hline $\begin{array}{l}90 / 12 / 24 \\
90 / 12 / 25 \\
90 / 12 / 26 \\
90 / 12 / 27 \\
90 / 12 / 28\end{array}$ & $\begin{array}{l}102.62 \\
102.18 \\
102.12 \\
101.84 \\
100.80\end{array}$ & $\begin{array}{l}103.03 \\
102.44 \\
102.25 \\
102.24 \\
101.26\end{array}$ & $\begin{array}{l}102.19 \\
102.04 \\
102.01 \\
101.35 \\
100.56\end{array}$ & $\begin{array}{l}91 / 02 / 12 \\
91 / 02 / 13 \\
91 / 02 / 14 \\
91 / 02 / 15 \\
91 / 02 / 16\end{array}$ & $\begin{array}{l}101.75 \\
102.00 \\
102.04 \\
101.51 \\
101.15\end{array}$ & $\begin{array}{l}101.89 \\
102.17 \\
102.32 \\
101.80 \\
101.31\end{array}$ & $\begin{array}{l}101.58 \\
101.87 \\
101.78 \\
101.26 \\
100.93\end{array}$ \\
\hline $\begin{array}{l}90 / 12 / 29 \\
90 / 12 / 30 \\
90 / 12 / 31 \\
91 / 01 / 01 \\
91 / 01 / 02\end{array}$ & $\begin{array}{l}101.52 \\
102.68 \\
102.67 \\
102.40 \\
102.28\end{array}$ & $\begin{array}{l}102.47 \\
102.89 \\
102.87 \\
102.61 \\
102.48\end{array}$ & $\begin{array}{l}100.75 \\
102.50 \\
102.47 \\
102.20 \\
102.13\end{array}$ & $\begin{array}{l}91 / 02 / 17 \\
91 / 02 / 18 \\
91 / 02 / 19 \\
91 / 02 / 20 \\
91 / 02 / 21\end{array}$ & $\begin{array}{l}101.48 \\
102.22 \\
102.68 \\
102.52 \\
102.11\end{array}$ & $\begin{array}{l}101.85 \\
102.56 \\
102.92 \\
102.81 \\
102.34\end{array}$ & $\begin{array}{l}101.31 \\
101.89 \\
102.49 \\
102.21 \\
101.88\end{array}$ \\
\hline $\begin{array}{l}91 / 01 / 03 \\
91 / 01 / 04 \\
91 / 01 / 05 \\
91 / 01 / 06 \\
91 / 01 / 07\end{array}$ & $\begin{array}{l}101.84 \\
101.46 \\
101.88 \\
102.29 \\
102.19\end{array}$ & $\begin{array}{l}102.12 \\
101.69 \\
102.18 \\
102.46 \\
102.34\end{array}$ & $\begin{array}{l}101.54 \\
101.31 \\
101.67 \\
102.17 \\
102.06\end{array}$ & $\begin{array}{l}91 / 02 / 22 \\
91 / 02 / 23 \\
91 / 02 / 24 \\
91 / 02 / 25 \\
91 / 02 / 26\end{array}$ & $\begin{array}{l}101.55 \\
101.44 \\
101.87 \\
102.12 \\
101.64\end{array}$ & $\begin{array}{l}101.86 \\
101.63 \\
102.12 \\
102.41 \\
101.91\end{array}$ & $\begin{array}{l}101.27 \\
101.26 \\
101.59 \\
101.84 \\
101.34\end{array}$ \\
\hline $\begin{array}{l}91 / 01 / 08 \\
91 / 01 / 09 \\
91 / 01 / 10 \\
91 / 01 / 11 \\
91 / 01 / 12\end{array}$ & $\begin{array}{l}101.84 \\
101.62 \\
102.19 \\
102.57 \\
102.55\end{array}$ & $\begin{array}{l}102.10 \\
101.90 \\
102.47 \\
102.75 \\
102.78\end{array}$ & $\begin{array}{l}101.58 \\
101.44 \\
101.93 \\
102.42 \\
102.42\end{array}$ & $\begin{array}{l}91 / 02 / 27 \\
91 / 02 / 28 \\
91 / 03 / 01 \\
91 / 03 / 02 \\
91 / 03 / 03\end{array}$ & $\begin{array}{r}100.90 \\
99.96 \\
99.84 \\
101.70 \\
102.02\end{array}$ & $\begin{array}{l}101.33 \\
100.25 \\
100.69 \\
102.21 \\
102.26\end{array}$ & $\begin{array}{r}100.33 \\
99.64 \\
99.52 \\
100.83 \\
101.80\end{array}$ \\
\hline $\begin{array}{l}91 / 01 / 13 \\
91 / 01 / 14 \\
91 / 01 / 15 \\
91 / 01 / 16 \\
91 / 01 / 17\end{array}$ & $\begin{array}{l}102.28 \\
102.40 \\
101.89 \\
102.33 \\
102.46\end{array}$ & $\begin{array}{l}102.46 \\
102.67 \\
102.27 \\
102.53 \\
102.65\end{array}$ & $\begin{array}{l}102.05 \\
102.28 \\
101.49 \\
102.02 \\
102.21\end{array}$ & $\begin{array}{l}91 / 03 / 04 \\
91 / 03 / 05 \\
91 / 03 / 06 \\
91 / 03 / 07 \\
91 / 03 / 08\end{array}$ & $\begin{array}{l}101.25 \\
101.05 \\
101.57 \\
101.96 \\
101.86\end{array}$ & $\begin{array}{l}101.79 \\
101.41 \\
101.81 \\
102.24 \\
102.04\end{array}$ & $\begin{array}{l}100.85 \\
100.87 \\
101.34 \\
101.67 \\
101.68\end{array}$ \\
\hline $\begin{array}{l}91 / 01 / 18 \\
91 / 01 / 19 \\
91 / 01 / 20 \\
91 / 01 / 21 \\
91 / 01 / 22\end{array}$ & $\begin{array}{l}102.17 \\
101.85 \\
101.77 \\
102.17 \\
101.97\end{array}$ & $\begin{array}{l}102.48 \\
102.07 \\
101.94 \\
102.36 \\
102.28\end{array}$ & $\begin{array}{l}101.84 \\
101.64 \\
101.47 \\
101.88 \\
101.73\end{array}$ & $\begin{array}{l}91 / 03 / 09 \\
91 / 03 / 10 \\
91 / 03 / 11 \\
91 / 03 / 12 \\
91 / 03 / 13\end{array}$ & $\begin{array}{l}101.49 \\
100.86 \\
101.32 \\
101.77 \\
100.90\end{array}$ & $\begin{array}{l}101.77 \\
101.17 \\
101.89 \\
102.06 \\
101.41\end{array}$ & $\begin{array}{l}101.15 \\
100.49 \\
100.51 \\
101.44 \\
100.36\end{array}$ \\
\hline $\begin{array}{l}91 / 01 / 23 \\
91 / 01 / 24 \\
91 / 01 / 25 \\
91 / 01 / 26 \\
91 / 01 / 27\end{array}$ & $\begin{array}{l}101.91 \\
101.90 \\
101.88 \\
101.82 \\
101.55\end{array}$ & $\begin{array}{l}102.09 \\
102.09 \\
102.06 \\
102.03 \\
101.80\end{array}$ & $\begin{array}{l}101.76 \\
101.70 \\
101.70 \\
101.61 \\
101.30\end{array}$ & $\begin{array}{l}91 / 03 / 14 \\
91 / 03 / 15 \\
91 / 03 / 16 \\
91 / 03 / 17 \\
91 / 03 / 18\end{array}$ & $\begin{array}{l}100.56 \\
100.55 \\
101.48 \\
101.70 \\
101.00\end{array}$ & $\begin{array}{l}100.80 \\
101.04 \\
101.74 \\
101.95 \\
101.53\end{array}$ & $\begin{array}{l}100.30 \\
100.14 \\
101.10 \\
101.50 \\
100.28\end{array}$ \\
\hline $\begin{array}{l}91 / 01 / 28 \\
91 / 01 / 29 \\
91 / 01 / 30 \\
91 / 01 / 31 \\
91 / 02 / 01\end{array}$ & $\begin{array}{l}101.13 \\
102.04 \\
102.52 \\
102.51 \\
102.26\end{array}$ & $\begin{array}{l}101.34 \\
102.33 \\
102.65 \\
102.70 \\
102.45\end{array}$ & $\begin{array}{l}100.90 \\
101.31 \\
102.36 \\
102.31 \\
102.10\end{array}$ & $\begin{array}{l}91 / 03 / 19 \\
91 / 03 / 20 \\
91 / 03 / 21 \\
91 / 03 / 22 \\
91 / 03 / 23\end{array}$ & $\begin{array}{l}100.30 \\
100.49 \\
100.83 \\
101.84 \\
101.56\end{array}$ & $\begin{array}{l}100.80 \\
100.80 \\
101.44 \\
102.02 \\
101.83\end{array}$ & $\begin{array}{r}99.94 \\
100.25 \\
100.28 \\
101.49 \\
101.32\end{array}$ \\
\hline $\begin{array}{l}91 / 02 / 02 \\
91 / 02 / 03 \\
91 / 02 / 04 \\
91 / 02 / 05 \\
91 / 02 / 06\end{array}$ & $\begin{array}{l}102.20 \\
102.45 \\
102.48 \\
101.91 \\
102.13\end{array}$ & $\begin{array}{l}102.31 \\
102.63 \\
102.79 \\
102.10 \\
102.29\end{array}$ & $\begin{array}{l}102.04 \\
102.28 \\
102.18 \\
101.68 \\
101.97\end{array}$ & $\begin{array}{l}91 / 03 / 24 \\
91 / 03 / 25 \\
91 / 03 / 26 \\
91 / 03 / 27 \\
91 / 03 / 28\end{array}$ & $\begin{array}{l}101.00 \\
100.53 \\
100.51 \\
101.07 \\
101.82\end{array}$ & $\begin{array}{l}101.33 \\
100.64 \\
100.83 \\
101.57 \\
102.06\end{array}$ & $\begin{array}{l}100.52 \\
100.45 \\
100.37 \\
100.79 \\
101.61\end{array}$ \\
\hline
\end{tabular}


Table 4. Summary of barometric-pressure data collected at study site near Beatty, Nev., in 1990 and 1991 -Continued

\begin{tabular}{|c|c|c|c|c|c|c|c|}
\hline \multirow[b]{2}{*}{ Date } & \multicolumn{3}{|c|}{ Barometric pressure (kilopascals) } & \multirow[b]{2}{*}{ Date } & \multicolumn{3}{|c|}{ Barometric pressure (kilopascals) } \\
\hline & Mean & Maximum & Minimum & & Mean & Maximum & Minimum \\
\hline $91 / 03 / 29$ & 101.77 & 101.97 & 101.58 & $91 / 05 / 18$ & 101.03 & 101.27 & 100.72 \\
\hline $91 / 03 / 30$ & 102.13 & 102.35 & 101.96 & $91 / 05 / 19$ & 101.28 & 101.44 & 101.15 \\
\hline $91 / 03 / 31$ & 101.83 & 102.14 & 101.39 & $91 / 05 / 20$ & 100.90 & 101.18 & 100.55 \\
\hline $91 / 04 / 01$ & 101.35 & 101.77 & 101.10 & $91 / 05 / 21$ & 101.00 & 101.21 & 100.77 \\
\hline $91 / 04 / 02$ & 101.93 & 102.13 & 101.75 & $91 / 05 / 22$ & 101.34 & 101.51 & 101.17 \\
\hline $91 / 04 / 03$ & 102.14 & 102.35 & 101.97 & $91 / 05 / 23$ & 101.52 & 101.74 & 101.32 \\
\hline $91 / 04 / 04$ & 102.12 & 102.36 & 101.91 & $91 / 05 / 24$ & 101.38 & 101.67 & 101.07 \\
\hline $91 / 04 / 05$ & 101.66 & 101.93 & 101.32 & $91 / 05 / 25$ & 100.92 & 101.21 & 100.57 \\
\hline $91 / 04 / 06$ & 100.95 & 101.29 & 100.53 & $91 / 05 / 26$ & 100.67 & 100.80 & 100.44 \\
\hline $91 / 04 / 07$ & 101.18 & 101.44 & 100.95 & $91 / 05 / 27$ & 101.05 & 101.24 & 100.86 \\
\hline $91 / 04 / 08$ & 101.98 & 102.21 & 101.49 & $91 / 05 / 28$ & 101.29 & 101.54 & 101.06 \\
\hline $91 / 04 / 09$ & 101.82 & 102.24 & 101.26 & $91 / 05 / 29$ & 100.85 & 101.15 & 100.49 \\
\hline $91 / 04 / 10$ & 101.17 & 101.43 & 100.95 & $91 / 05 / 30$ & 100.24 & 100.55 & 997.65 \\
\hline $91 / 04 / 11$ & 101.35 & 101.50 & 101.16 & $91 / 05 / 31$ & 100.65 & 100.86 & 100.41 \\
\hline $91 / 04 / 12$ & 101.58 & 101.78 & 101.46 & $91 / 06 / 01$ & 101.15 & 101.38 & 100.88 \\
\hline $91 / 04 / 13$ & 101.71 & 101.97 & 101.43 & $91 / 06 / 02$ & 101.22 & 101.39 & 101.02 \\
\hline $91 / 04 / 14$ & 101.26 & 101.66 & 100.77 & $91 / 06 / 03$ & 101.14 & 101.37 & 100.91 \\
\hline $91 / 04 / 15$ & 100.59 & 100.84 & 100.22 & $91 / 06 / 04$ & 100.95 & 101.18 & 100.72 \\
\hline $91 / 04 / 16$ & 100.80 & 100.97 & 100.57 & $91 / 06 / 05$ & 100.97 & 101.12 & 100.80 \\
\hline $91 / 04 / 17$ & 101.12 & 101.31 & 100.72 & $91 / 06 / 06$ & 101.26 & 101.39 & 101.13 \\
\hline $91 / 04 / 18$ & 101.30 & 101.48 & 101.13 & $91 / 06 / 07$ & 101.39 & 101.61 & 101.18 \\
\hline $91 / 04 / 19$ & 101.32 & 101.51 & 101.13 & $91 / 06 / 08$ & 101.13 & 101.32 & 100.93 \\
\hline $91 / 04 / 20$ & 101.09 & 101.27 & 100.89 & $91 / 06 / 09$ & 101.24 & 101.42 & 101.08 \\
\hline $91 / 04 / 21$ & 101.29 & 101.48 & 101.13 & $91 / 06 / 10$ & 101.23 & 101.48 & 101.01 \\
\hline $91 / 04 / 22$ & 101.17 & 101.36 & 100.99 & $91 / 06 / 11$ & 101.14 & 101.40 & 100.89 \\
\hline $91 / 04 / 23$ & 101.07 & 101.28 & 100.86 & $91 / 06 / 12$ & 101.03 & 101.32 & 100.68 \\
\hline $91 / 04 / 24$ & 101.01 & 101.34 & 100.64 & $91 / 06 / 13$ & 100.88 & 101.11 & 100.60 \\
\hline $91 / 04 / 25$ & 100.91 & 101.18 & 100.77 & $91 / 06 / 14$ & 101.11 & 101.24 & 100.89 \\
\hline $91 / 04 / 26$ & 101.38 & 101.66 & 101.20 & $91 / 06 / 15$ & 101.34 & 101.53 & 101.15 \\
\hline $91 / 04 / 27$ & 101.53 & 101.76 & 101.31 & $91 / 06 / 16$ & 101.39 & 101.60 & 101.21 \\
\hline $91 / 04 / 28$ & 101.72 & 102.02 & 101.43 & $91 / 06 / 17$ & 101.34 & 101.54 & 101.12 \\
\hline $91 / 04 / 29$ & 101.41 & 101.61 & 101.12 & $91 / 06 / 18$ & 101.10 & 101.26 & 100.95 \\
\hline $91 / 04 / 30$ & 101.45 & 101.92 & 100.84 & $91 / 06 / 19$ & 101.07 & 101.27 & 100.90 \\
\hline $91 / 05 / 01$ & 100.53 & 100.79 & 100.35 & $91 / 06 / 20$ & 101.28 & 101.47 & 101.11 \\
\hline $91 / 05 / 02$ & 100.83 & 101.15 & 100.56 & $91 / 06 / 21$ & 101.11 & 101.28 & 100.91 \\
\hline $91 / 05 / 03$ & 101.34 & 101.69 & 101.15 & $91 / 06 / 22$ & 101.14 & 101.33 & 100.94 \\
\hline $91 / 05 / 04$ & 101.94 & 102.13 & 101.72 & $91 / 06 / 23$ & 101.06 & 101.26 & 100.84 \\
\hline $91 / 05 / 05$ & 102.07 & 102.38 & 101.75 & $91 / 06 / 24$ & 100.95 & 101.14 & 100.72 \\
\hline $91 / 05 / 06$ & 101.35 & 101.68 & 101.06 & $91 / 06 / 25$ & 101.09 & 101.30 & 100.90 \\
\hline $91 / 05 / 07$ & 101.35 & 101.60 & 101.08 & $91 / 06 / 26$ & 101.01 & 101.28 & 100.73 \\
\hline $91 / 05 / 08$ & 100.65 & 101.04 & 100.32 & $91 / 06 / 27$ & 100.79 & 100.95 & 100.61 \\
\hline $91 / 05 / 09$ & 100.72 & 101.08 & 100.30 & $91 / 06 / 28$ & 100.95 & 101.12 & 100.78 \\
\hline $91 / 05 / 10$ & 101.09 & 101.31 & 100.95 & $91 / 06 / 29$ & 101.21 & 101.38 & 100.92 \\
\hline $91 / 05 / 11$ & 101.54 & 101.69 & 101.31 & $91 / 06 / 30$ & 101.40 & 101.61 & 101.17 \\
\hline $91 / 05 / 12$ & 101.72 & 102.00 & 101.47 & $91 / 07 / 01$ & 101.32 & 101.53 & 101.11 \\
\hline $91 / 05 / 13$ & 100.92 & 101.41 & 100.38 & $91 / 07 / 02$ & 101.39 & 101.63 & 101.19 \\
\hline $91 / 05 / 14$ & 101.14 & 101.56 & 100.80 & $91 / 07 / 03$ & 101.38 & 101.65 & 101.14 \\
\hline $91 / 05 / 15$ & 101.52 & 101.77 & 101.29 & $91 / 07 / 04$ & 101.16 & 101.44 & 100.89 \\
\hline $91 / 05 / 16$ & 101.07 & 101.44 & 100.61 & $91 / 07 / 05$ & 101.04 & 101.22 & 100.83 \\
\hline $91 / 05 / 17$ & 100.65 & 100.94 & 100.30 & $91 / 07 / 06$ & 101.25 & 101.39 & 101.11 \\
\hline
\end{tabular}


Tabie 4. Summary of barometric-pressure data collected at study site near Beatty, Nev., in 1990 and 1991 -Continued

\begin{tabular}{|c|c|c|c|c|c|c|c|}
\hline \multirow[b]{2}{*}{ Date } & \multicolumn{3}{|c|}{ Barometric pressure (kilopascals) } & \multirow[b]{2}{*}{ Date } & \multicolumn{3}{|c|}{ Barometric pressure (kilopascals) } \\
\hline & Mean & Maximum & Minlmum & & Mean & MaxImum & MlnImum \\
\hline $91 / 07 / 07$ & 101.51 & 101.62 & 101.38 & $91 / 08 / 26$ & 101.44 & 101.69 & 101.19 \\
\hline $91 / 07 / 08$ & 101.56 & 101.74 & 101.32 & $91 / 08 / 27$ & 101.28 & 101.47 & 101.10 \\
\hline $91 / 07 / 09$ & 101.21 & 101.44 & 100.90 & $91 / 08 / 28$ & 101.23 & 101.55 & 100.96 \\
\hline $91 / 07 / 10$ & 101.33 & 101.51 & 101.15 & $91 / 08 / 29$ & 101.73 & 101.88 & 101.57 \\
\hline $91 / 07 / 11$ & 101.54 & 101.66 & 101.37 & $91 / 08 / 30$ & 101.92 & 102.10 & 101.77 \\
\hline $91 / 07 / 12$ & 101.65 & 101.85 & 101.46 & $91 / 08 / 31$ & 101.71 & 101.97 & 101.50 \\
\hline $91 / 07 / 13$ & 101.40 & 101.64 & 101.13 & $91 / 09 / 01$ & 101.55 & 101.69 & 101.38 \\
\hline $91 / 07 / 14$ & 101.31 & 101.51 & 101.11 & $91 / 09 / 02$ & 101.56 & 101.72 & 101.34 \\
\hline $91 / 07 / 15$ & 101.43 & 101.59 & 101.28 & $91 / 09 / 03$ & 101.81 & 101.95 & 101.64 \\
\hline $91 / 07 / 16$ & 101.64 & 101.84 & 101.47 & $91 / 09 / 04$ & 101.90 & 102.15 & 101.67 \\
\hline $91 / 07 / 17$ & 101.39 & 101.67 & 101.11 & $91 / 09 / 05$ & 101.42 & 101.75 & 101.15 \\
\hline $91 / 07 / 18$ & 101.13 & 101.38 & 100.88 & $91 / 09 / 06$ & 101.37 & 101.58 & 101.12 \\
\hline $91 / 07 / 19$ & 101.07 & 101.21 & 100.90 & $91 / 09 / 07$ & 101.56 & 101.70 & 101.37 \\
\hline $91 / 07 / 20$ & 101.36 & 101.53 & 101.20 & $91 / 09 / 08$ & 101.69 & 101.89 & 101.54 \\
\hline $91 / 07 / 21$ & 101.66 & 101.85 & 101.49 & $91 / 09 / 09$ & 101.20 & 101.62 & 100.81 \\
\hline $91 / 07 / 22$ & 101.61 & 101.81 & 101.38 & $91 / 09 / 10$ & 100.80 & 101.12 & 100.56 \\
\hline $91 / 07 / 23$ & 101.50 & 101.71 & 101.27 & $91 / 09 / 11$ & 101.40 & 101.48 & 101.18 \\
\hline $91 / 07 / 24$ & 101.31 & 101.57 & 101.02 & $91 / 09 / 12$ & 101.50 & 101.67 & 101.30 \\
\hline $91 / 07 / 25$ & 101.20 & 101.38 & 101.00 & $91 / 09 / 13$ & 101.53 & 101.74 & 101.35 \\
\hline $91 / 07 / 26$ & 101.53 & 101.68 & 101.30 & $91 / 09 / 14$ & 101.40 & 101.65 & 101.22 \\
\hline $91 / 07 / 27$ & 101.84 & 102.05 & 101.66 & $91 / 09 / 15$ & 101.34 & 101.52 & 101.13 \\
\hline $91 / 07 / 28$ & 101.77 & 102.02 & 101.51 & $91 / 09 / 16$ & 101.73 & 101.91 & 101.55 \\
\hline $91 / 07 / 29$ & 101.56 & 101.73 & 101.31 & $91 / 09 / 17$ & 101.79 & 102.08 & 101.54 \\
\hline $91 / 07 / 30$ & 101.70 & 101.95 & 101.44 & $91 / 09 / 18$ & 101.54 & 101.77 & 101.31 \\
\hline $91 / 07 / 31$ & 101.86 & 102.05 & 101.60 & $91 / 09 / 19$ & 101.45 & 101.64 & 101.22 \\
\hline $91 / 08 / 01$ & 101.60 & 101.79 & 101.38 & $91 / 09 / 20$ & 101.48 & 101.72 & 101.24 \\
\hline $91 / 08 / 02$ & 101.33 & 101.55 & 101.04 & $91 / 09 / 21$ & 101.38 & 101.65 & 101.11 \\
\hline $91 / 08 / 03$ & 101.30 & 101.51 & 101.07 & $91 / 09 / 22$ & 101.43 & 101.67 & 101.18 \\
\hline $91 / 08 / 04$ & 101.22 & 101.44 & 100.99 & $91 / 09 / 23$ & 101.83 & 101.99 & 101.61 \\
\hline $91 / 08 / 05$ & 101.14 & 101.33 & 100.90 & $91 / 09 / 24$ & 101.82 & 101.99 & 101.60 \\
\hline $91 / 08 / 06$ & 101.22 & 101.37 & 101.09 & $91 / 09 / 25$ & 101.93 & 102.18 & 101.75 \\
\hline $91 / 08 / 07$ & 101.67 & 101.82 & 101.37 & $91 / 09 / 26$ & 101.73 & 102.00 & 101.49 \\
\hline $91 / 08 / 08$ & 101.74 & 102.01 & 101.48 & $91 / 09 / 27$ & 101.51 & 101.74 & 101.24 \\
\hline $91 / 08 / 09$ & 101.31 & 101.59 & 100.95 & $91 / 09 / 28$ & 101.36 & 101.56 & 101.16 \\
\hline $91 / 08 / 10$ & 101.25 & 101.58 & 101.06 & $91 / 09 / 29$ & 101.50 & 101.64 & 101.31 \\
\hline $91 / 08 / 11$ & 101.78 & 101.92 & 101.58 & $91 / 09 / 30$ & 101.85 & 102.10 & 101.64 \\
\hline $91 / 08 / 12$ & 101.96 & 102.06 & 101.81 & $91 / 10 / 01$ & 102.13 & 102.33 & 101.94 \\
\hline $91 / 08 / 13$ & 101.76 & 102.03 & 101.43 & $91 / 10 / 02$ & 101.85 & 102.18 & 101.62 \\
\hline $91 / 08 / 14$ & 101.37 & 101.55 & 101.15 & $91 / 10 / 03$ & 101.51 & 101.85 & 101.28 \\
\hline $91 / 08 / 15$ & 101.51 & 101.67 & 101.37 & $91 / 10 / 04$ & 101.36 & 101.56 & 101.19 \\
\hline $91 / 08 / 16$ & 101.70 & 101.90 & 101.52 & $91 / 10 / 05$ & 101.54 & 101.69 & 101.37 \\
\hline $91 / 08 / 17$ & 101.62 & 101.83 & 101.39 & $91 / 10 / 06$ & 101.68 & 101.84 & 101.53 \\
\hline $91 / 08 / 18$ & 101.50 & 101.69 & 101.30 & $91 / 10 / 07$ & 101.74 & 101.98 & 101.54 \\
\hline $91 / 08 / 19$ & 101.58 & 101.76 & 101.44 & $91 / 10 / 08$ & 101.61 & 101.81 & 101.41 \\
\hline $91 / 08 / 20$ & 101.59 & 101.76 & 101.44 & $91 / 10 / 09$ & 101.78 & 101.93 & 101.64 \\
\hline $91 / 08 / 21$ & 101.70 & 101.87 & 101.53 & $91 / 10 / 10$ & 102.01 & 102.17 & 101.87 \\
\hline $91 / 08 / 22$ & 101.86 & 102.04 & 101.72 & $91 / 10 / 11$ & 102.02 & 102.32 & 101.81 \\
\hline $91 / 08 / 23$ & 101.68 & 101.99 & 101.41 & $91 / 10 / 12$ & 101.68 & 101.95 & 101.45 \\
\hline $91 / 08 / 24$ & 101.43 & 101.69 & 101.17 & $91 / 10 / 13$ & 101.64 & 101.79 & 101.50 \\
\hline $91 / 08 / 25$ & 101.48 & 101.66 & 101.25 & $91 / 10 / 14$ & 101.97 & 102.13 & 101.81 \\
\hline
\end{tabular}


Table 4. Summary of barometric-pressure data collected at study site near Beatty, Nev., in 1990 and 1991 -Continued

\begin{tabular}{|c|c|c|c|c|c|c|c|}
\hline \multirow[b]{2}{*}{ Date } & \multicolumn{3}{|c|}{ Barometric pressure (kilopascals) } & \multirow[b]{2}{*}{ Date } & \multicolumn{3}{|c|}{ Barometric pressure (kilopascals) } \\
\hline & Mean & Maximum & Minimum & & Mean & Maximum & Minimum \\
\hline $91 / 10 / 15$ & 102.05 & 102.34 & 101.86 & $91 / 11 / 24$ & 103.07 & 103.40 & 102.76 \\
\hline $91 / 10 / 16$ & 101.61 & 101.92 & 101.36 & $91 / 11 / 25$ & 102.43 & 102.74 & 102.25 \\
\hline $91 / 10 / 17$ & 101.36 & 101.52 & 101.15 & $91 / 11 / 26$ & 102.13 & 102.33 & 101.96 \\
\hline $91 / 10 / 18$ & 101.75 & 102.05 & 101.49 & $91 / 11 / 27$ & 101.93 & 102.19 & 101.69 \\
\hline $91 / 10 / 19$ & 102.15 & 102.39 & 102.01 & $91 / 11 / 28$ & 101.25 & 101.62 & 100.60 \\
\hline $91 / 10 / 20$ & 101.70 & 102.07 & 101.45 & $91 / 11 / 29$ & 101.60 & 101.75 & 101.22 \\
\hline $91 / 10 / 21$ & 101.37 & 101.63 & 101.19 & $91 / 11 / 30$ & 101.12 & 101.52 & 100.84 \\
\hline $91 / 10 / 22$ & 101.08 & 101.38 & 100.87 & $91 / 12 / 01$ & 101.96 & 102.40 & 101.58 \\
\hline $91 / 10 / 23$ & 100.88 & 101.07 & 100.70 & $91 / 12 / 02$ & 102.42 & 102.73 & 102.26 \\
\hline $91 / 10 / 24$ & 101.10 & 101.35 & 100.90 & $91 / 12 / 03$ & 102.24 & 102.51 & 101.98 \\
\hline $91 / 10 / 25$ & 101.24 & 101.45 & 101.06 & $91 / 12 / 04$ & 102.59 & 102.86 & 102.36 \\
\hline $91 / 10 / 26$ & 101.15 & 101.36 & 100.99 & $91 / 12 / 05$ & 102.02 & 102.32 & 101.75 \\
\hline $91 / 10 / 27$ & 100.63 & 101.01 & 100.15 & $91 / 12 / 06$ & 101.82 & 102.01 & 101.67 \\
\hline $91 / 10 / 28$ & 101.23 & 101.78 & 100.73 & $91 / 12 / 07$ & 101.60 & 101.92 & 101.28 \\
\hline $91 / 10 / 29$ & 101.71 & 101.89 & 101.48 & $91 / 12 / 08$ & 101.21 & 101.60 & 100.97 \\
\hline $91 / 10 / 30$ & 101.34 & 101.88 & 100.93 & $91 / 12 / 09$ & 102.05 & 102.36 & 101.63 \\
\hline $91 / 10 / 31$ & 102.36 & 102.53 & 101.95 & $91 / 12 / 10$ & 102.25 & 102.61 & 101.86 \\
\hline $91 / 11 / 01$ & 102.28 & 102.61 & 102.07 & $91 / 12 / 11$ & 101.44 & 101.78 & 101.17 \\
\hline $91 / 11 / 02$ & 102.00 & 102.24 & 101.76 & $91 / 12 / 12$ & 101.45 & 101.89 & 101.21 \\
\hline $91 / 11 / 03$ & 102.16 & 102.55 & 101.91 & $91 / 12 / 13$ & 102.09 & 102.31 & 101.89 \\
\hline $91 / 11 / 04$ & 102.62 & 102.80 & 102.48 & $91 / 12 / 14$ & 102.58 & 102.74 & 102.31 \\
\hline $91 / 11 / 05$ & 102.44 & 102.75 & 102.25 & $91 / 12 / 15$ & 102.65 & 102.87 & 102.50 \\
\hline $91 / 11 / 06$ & 102.00 & 102.28 & 101.77 & $91 / 12 / 16$ & 102.51 & 102.72 & 102.33 \\
\hline $91 / 11 / 07$ & 101.74 & 101.92 & 101.49 & $91 / 12 / 17$ & 102.28 & 102.52 & 102.07 \\
\hline $91 / 11 / 08$ & 102.01 & 102.16 & 101.85 & $91 / 12 / 18$ & 101.81 & 102.06 & 101.61 \\
\hline $91 / 11 / 09$ & 101.72 & 102.02 & 101.49 & $91 / 12 / 19$ & 101.35 & 101.68 & 101.00 \\
\hline $91 / 11 / 10$ & 101.48 & 101.63 & 101.28 & $91 / 12 / 20$ & 101.70 & 102.38 & 101.14 \\
\hline $91 / 11 / 11$ & 101.66 & 101.91 & 101.44 & $91 / 12 / 21$ & 102.48 & 102.64 & 102.38 \\
\hline $91 / 11 / 12$ & 102.09 & 102.28 & 101.90 & $91 / 12 / 22$ & 102.06 & 102.37 & 101.83 \\
\hline $91 / 11 / 13$ & 102.07 & 102.37 & 101.70 & $91 / 12 / 23$ & 102.15 & 102.26 & 101.99 \\
\hline $91 / 11 / 14$ & 100.98 & 101.64 & 100.39 & $91 / 12 / 24$ & 102.01 & 102.25 & 101.78 \\
\hline $91 / 11 / 15$ & 100.59 & 100.83 & 100.31 & $91 / 12 / 25$ & 101.67 & 101.85 & 101.46 \\
\hline $91 / 11 / 16$ & 101.31 & 101.84 & 100.80 & $91 / 12 / 26$ & 101.78 & 101.92 & 101.63 \\
\hline $91 / 11 / 17$ & 101.90 & 102.12 & 101.69 & $91 / 12 / 27$ & 101.99 & 102.16 & 101.88 \\
\hline $91 / 11 / 18$ & 101.16 & 101.67 & 100.73 & $91 / 12 / 28$ & 101.63 & 102.08 & 101.16 \\
\hline $91 / 11 / 19$ & 101.93 & 102.67 & 101.03 & $91 / 12 / 29$ & 101.25 & 101.38 & 101.11 \\
\hline $91 / 11 / 20$ & 102.90 & 103.11 & 102.64 & $91 / 12 / 30$ & 101.19 & 101.34 & 101.09 \\
\hline $91 / 11 / 21$ & 102.53 & 102.91 & 102.08 & $91 / 12 / 31$ & 101.78 & 102.19 & 101.24 \\
\hline $91 / 11 / 22$ & 102.03 & 102.28 & 101.74 & & & & \\
\hline $91 / 11 / 23$ & 102.74 & 103.19 & 102.37 & & & & \\
\hline
\end{tabular}

